

\section{EX LIBRIS}

The Cooper Union

THE GIFT OF

Miss Eleanor Hewitt

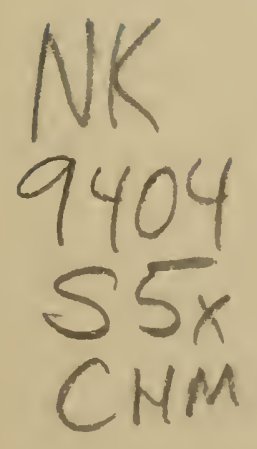


- 



\section{POINT AND PILLOW LACE}






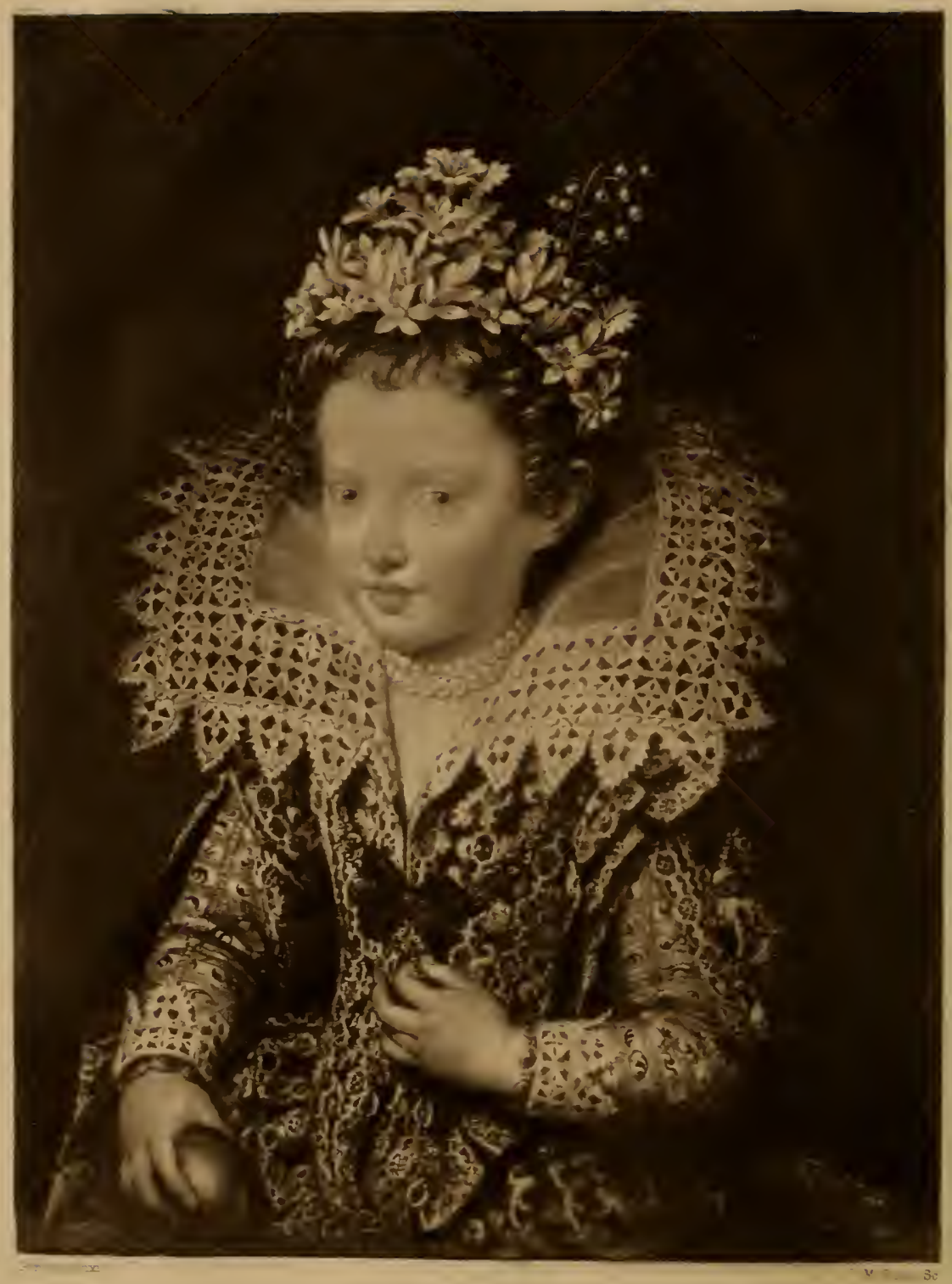

Pretrait of the

- Prinerfo Elemera of C Mantura. 


\title{
POINT AND PILLOW LACE
}

A SHORT ACCOUNT OF VARIOUS KINDS ANCIENT AND MODERN, AND HOW

TO RECOGNISE THEM

\author{
By A. M. S $:=$
}

\section{LONDON}

JOHN MURRAY, ALBEMARLE STREET I 899 


$$
\begin{aligned}
& \text { dK } \\
& 9404 \\
& 558 \\
& \text { CAn }
\end{aligned}
$$




\section{PREFACE}

THE object of this little book is to supply to owners and lovers of Lace some clear information easily referred to, by means of which they can ascertain the true name and nature of any particular specimen.

The valuable works of which a list is given on page xiii, as the authorities consulted, are some of them, especially the late Mrs. Palliser's History of Lace, almost exhaustive as to the historical records on the subject, and they also contain a great deal of interesting information concerning the various lace manufactures. Yet the writer has found, in common she believes with others, that a diligent search through many volumes and much inquiry of experts has been necessary before some particular piece of Lace could be identified, even if in the end that identification did not appear doubtful.

In the present volume it is hoped that the simple statements distinguishing the features of each variety will enable the reader to recognise them readily, especially as each description is accompanied by an

$$
2.02588
$$


illustration, on as large a scale as the size of the page will allow, so that the texture of the Lace may be the more easily seen.

Description alone, however good, without illustrations is very insufficient: this will readily be allowed by anyone who attempts the task of explaining in words the nature and peculiarities of any kind of Lace. Dr. Johnson gives as a definition of "net," "a texture woven with intersticial vacuities," and of " network," "anything reticulated or decussated, at equal distances, with interstices between the intersections." Where the great lexicographer failed to make his meaning more intelligible to simple folk, lesser mortals may well be glad to eke out their otherwise insufficient explanations by the help of the photographer.

One difficulty attendant on the study of Lace must be mentioned. It is that at various times the same kinds of Lace were made in different localities, each imitating the other. Thus Brussels and Alençon copied Venice, and Italy in turn adopted the "réseau" ground in imitation of Flanders; nor is the reason far to seek. The laws of supply and demand were in force three hundred years ago as now, and though we are apt to think of the countries of Europe, before the days of railways and steamboats, as isolated, yet 
a very cursory study of history is enough to prove that it was far otherwise. The number of travellers was no doubt much less than at present, but the richer classes were socially in constant communication with each other everywhere, as is indeed evidenced by the prevalence of the same fashions in dress throughout Europe at any given time. No sooner dic the ladies of Paris in the time of Henry the Fourth adopt the high ruff, than English ladies hastened to do the same; and as soon as the Pillow laces of Genoa were admired and found suitable to the falling collars of the succeeding reigns, the laceworkers of Flanders were quick in learning to reproduce the style, in this case so exactly, that but little difference can now be detected between their work and that of the Italians. Lace also was largely made in convents and lace-making was taught in convent schools; and the fact that nuns were of all nationalities helps to account for the cosmopolitan character of the Art.

It will not be attempted here to decide from what locality any particular Lace may have come, but merely to state on good authority to what style it belongs, and to assist the reader, by a careful clescription of its details, to judge for himself or herself of its character. Of all the decorative works of Art 
Lace is by far the most perishable; indeed, it may be said that the more beautiful the Lace, the more delicate and more easily destroyed it is.

Much has disappeared long ago, and in the hands of ignorant owners the little that has lasted till now is in danger of being finally lost. If, therefore, what is here written should attract the notice of some who have taken but small care of their frail possessions, and have, without scruple, given them over to the tender mercies of the dressmaker who cuts, or the washerwoman who tears, and if they should be induced henceforth to pay more heed to these irreplaceable treasures, the writer will feel that she has not written in vain on a subject which has long been one of great interest to herself.

She cannot send this little book into the world without expressing her thanks to Mr. Alan Cole, of the Science and Art Department, South Kensington, for the help and advice that he has been good enough to give her on a subject on which he is so well-known an authority; also to the kind friends to whom she is indebted for the loan of many beautiful specimens of lace here represented. Without such assistance and encouragement her pleasant task might never have been accomplished at all.

A. M. S.

UfTON COURT, July, I899. 


\section{CONTENTS}

PREFACE

LisT OF ILLUSTRATIONS

Authorities Consulted

A Glossary of Terms

PAGE

V

$\mathrm{xi}$

xiii

$\mathrm{XV}$

\section{CHAPTER I.}

Of Lace in General .

I

How to discriminate between Point and Pillow lace-Antiquity of Lace--Chief centres of lace-making: Venice, Flanders and Alençon.

\section{CHAPTER II.}

Of Italjan NeEdLe Lace

Styles and periods--Drawn-work-Darned-netting-Cut-workReticella, or Greek Lace-The uses to which such linen Lace was put.

\section{CHAPTER III.}

OF ITAlian NeEdle Lace (continued)

Punto in Aria - Ruffs - Pattern books-Falling collars-Extravagance in the use of Lace-Venetian Points-Three periods-Raised PointFlat Point-Grounded Venetian Point-Old Burano Point-RevivalSpanish Lace.

\section{CHAPTER IV.}

Of Italian Pillow Lace

Knotted Lace (Macramé) - Origin of Pillow lace-Pillow GuipureMixed Guipure-Genoese Lace-Collar Laces-Plaited Lace-Punto di Genoa-Punto di Milano-Country Laces-Maltese Lace. 


\section{CHAPTER V.}

OF French LaCE

Establishment of lace-making at Alençon by Colbert-La Revolte des Passemens-Earliest Lace made at Alençon (Point de France)-Three styles of Alençon Lace : Point d'Argentan-Old Valenciennes, Fausse and Traie-Point de Paris-Lille-Chantilly-Blonde.

\section{CHAPTER VI.}

OF Flemish LaCE

Earliest style Pillow Guipure-Invention of Réseau-Brussels Lace -Method of work-Peculiarities-Styles-P'oint d'Angleterre-Point plat appliqué-Duchesse-Brussels Needle-pnint-Point appliqué -Point de Gaze-Mechlin, early and later styles-Binche--YpresAntwerp-Trolle Kant.

CHAPTER VII.

OF ENGLish ANd IRISH LACES .

I6 I

Cut-work-Honiton-Styles-Buckinghamshire and BedfordshireIrish Laces : Limerick-Carrickmacross-Machine-made lace.

A Sumiary

INDEX 


\section{LIST OF ILLUSTRATIONS}

Portrait of the Princess Eleonora of Mantua, Pitti Palace, Florence,

Frontispiece PAGE

I. Details of Needle-point lace

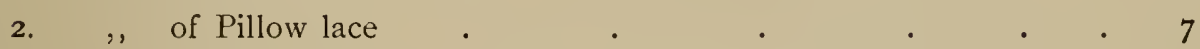

3. Medireval Drawn-work . . . . . . $\quad$ I7

4. Darned netting (lent by Mrs. Lathbury) . . . . 2 I

5. Cut-work . $\quad$. $\quad$. $\quad . \quad$. 25

6. Reticella and Punto in Aria . . . . . 29

7. Kaised Venetian Point (South Kensington Museum) . . . 39

8. Rose Point Venetian (South Kensington Museum) . . . 43

9. Flat Venetian Point (lent by Mrs. Tonge) . . . . 47

Io. Coraline Venetian Point (lent by Mrs. Norman Pearson). . . 5 r

II. Grounded Venetian Point (lent by Mrs. Tonge) . . . 54

12. Old Burano Point . $\quad$. $\quad$. $\quad . \quad 57$

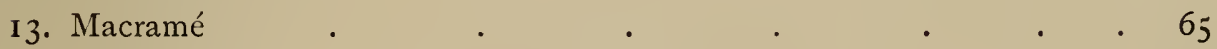

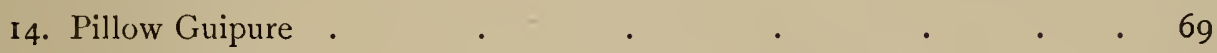

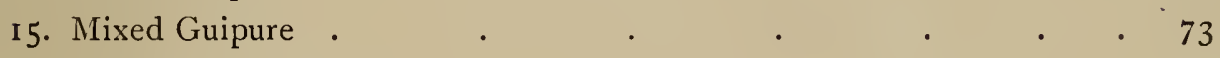

I6. Genoese Collar Lace $\quad . \quad$. $\quad$. $\quad$. $\quad$. 77

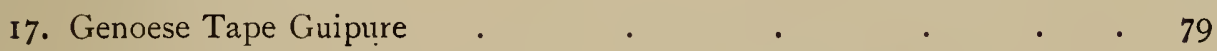

18. Milanese Pillow Lace (lent by Mrs. Lovett Cameron) . . . 83

19. Italian Peasant Lace $\quad . \quad$. $\quad . \quad$. $\quad . \quad$. 85

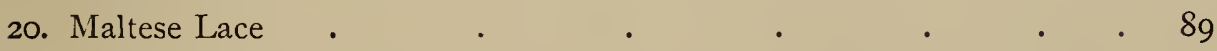

2I. A Lappet, Point d'Alençon $\quad$. $\quad$ - $\quad$. $\quad$. 93

22. Point d'Alençon, (I) lent by Mrs. Lovett Cameron; (2) lent by Miss

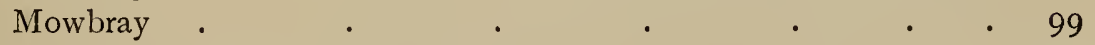

23. Point d'Argentan (lent by Lady Hunter) . . . . I03

24. Old Valenciennes (two specimens) . . . . . 107 
25. A Lappet, Old Valenciennes (lent by Lady Hunter) . . . . Io9

26. Lille and Point de Paris . . . . . . II I

27. Chantilly (lent by Lady Pearson) . . . . . I I5

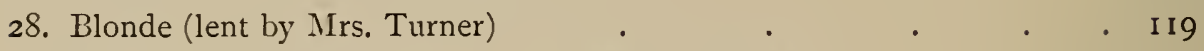

29. Flemish Guipure, (I) lent by Lady Maxwell Lyte ;

(2) lent by Mrs. Willink . . . . I23

30. Point d'Angleterre . . . . . . I30

3r. Point d'Angleterre à brides (lent by Lady Hunter) . . . I33

32. Brussels Pillow lace: Point Plat appliqué and Duchesse . . . I37

33. Brussels Needle-point: Old and Modern . . . . I42

34. Brussels Needle-point : Point de Gaze • • I45

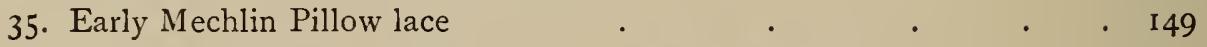

36. Later Mechlin (two specimens ; No. 2 lent by Mrs. Lathbury) . . I53

37. Binche (lent by Mrs. Henry Reeve) and old Flemish . . . 155

38. Antwerp Pot lace (lent by Mrs. Lathbury) . $\quad$ • . I59

Heading of page, Limerick Lace (lent by Miss Stroud) . . . I6I

39. Old English Sampler (South Kensington Museum) . . . I63

40. Honiton (two specimens; No. I lent by Mrs. Crutwell) . . . I69

4I. Buckinghamshire (two specimens; (1) lent by Mrs. Savill Young;

(2) lent by Mrs. Lathbury) . . . . . I74

42. Old Lace Chest belonging to Mrs. Forrest . . . . . 178

43. Carrickmacross Lace . $\quad$. $\quad . \quad$. 185

Tailpiece: Old English bobbins belonging to Mrs. Baker and a Lace token belonging to Mrs. Forrest . . . . . Igo 


\section{AUTHORITIES CONSULTED}

Alan Cole, Ancient Needle-point and Pillow Lace.

Brazza, A Guide to Old and New Lace in Italy.

Cutalogue of South Kensington Museum.

Madame Despierres, Histoire du Point d'Alençon.

Doumert, La Dentelle.

Felkin, Machine-wrought Lace.

Lefebure, Embroidery and Lace.

Mrs. Palliser, History of Lace.

Seguin, La Dentelle.

Mrs. Treadwin, Antique Point and Honiton.

The "Queen" Lace Book.

Urbani Gheltof, Trattato Storico. 



\section{A GLOSSARY OF TERMS USED}

Point lace.-From the French "point," a stitch-properly applied only to Lace made with needle stitches, or Needle-point lace. This term has been often much misapplied. Neither "Point d'Angleterre," nor "Punto di Milano," nor "Honiton Point" are Point laces at all in the proper sense of the words; they are Pillow lace.

Pillow lace, or Bone lace, or Dentelle au fuseau, or Merletti a Piombini, is Lace made on the pillow with bobbins; hence the English, French and Italian names, the bobbins being sometimes made of bone or lead as well as of wood.

Toilé.-. The substance of the pattern as contrasted with the groundwork.

Réseau.-The network ground in which the pattern is sometimes set.

Brides.-The slender stalks or ties connecting different parts of the pattern together when not on a net ground.

Picots.-The knots or thorns which often decorate "brides" and also the edges of the pattern.

$\dot{A}$ jours.-The open ornamental work introduced in enclosed spaces.

Cordonnet.-The thick thread or cord with which the pattern is often outlined.

Applique denotes when the pattern, either Needlework or Pillow, is made separately and afterwards sewn on to a net ground.

Guipure.-The cord or gimp sometimes overcast with stitches; frequently used for outlining heavy Laces. "Guiper" is an old verb, meaning to roll round a cord. The term "Guipure" has often been wrongly applied to various kinds of Lace. It is here used to denote only Lace of which the pattern consists of a cord or tape connected by "brides." 



\section{POINT AND PILLOW LACE}

CHAPTER I.

\section{OF LACE IN GENERAL.}

The English word Lace is taken from the French "Lacis," a term however, which, when properly used, denotes only the Italian work "Punto a maglia," or Darned netting.

There are two distinct kinds of Hand-made lace; first, Lace made with the needle, that is, Needle-point lace, under which heading the above-mentioned Darned netting may be included, and secondly, Lace made on a pillow with bobbins, that is, Pillow lace.

Machine-made lace will be treated of in a separate section later on, and is not now therefore taken into account.

In order to distinguish between Needle-point and Pillow lace, and to decide to which of the two classes any particular specimen belongs, both the 
"toile" * or solid part of the pattern and also the grounding, whether of "brides" or of network, should be closely examined.

In Needle-point lace the solid parts are always made of rows of looped, or so-called button-hole stitches, sometimes quite closely worked, as in the specimen given in Fig. I, Illustration I., sometimes looser or with small open spaces left in patterns; still the stitch used is always the same.

The "brides" in Needle-point consist of one or two threads fastened across from one part of the pattern to another and then closely whipped or button-holed over; they are usually more or less decorated with "picots," made much in the same manner as the "bride" itself. (See Fig. 5, Illustration I.)

But Needle-point is also sometimes grounded with "réseau" or network, and still this when examined will be found to be made with the same stitch. The meshes of the network are merely loose looped stitches; sometimes the needle is twisted a second time in each stitch to keep the mesh open, as in Fig. 2, Illustration I.; sometimes the work is strengthened with a second thread, which is whipped

* For an explanation of all technical terms used throughout this book see Glossary, p. xv. 
DETAILS OF NEEDLE-POINT LACE, MAGNIFIED.

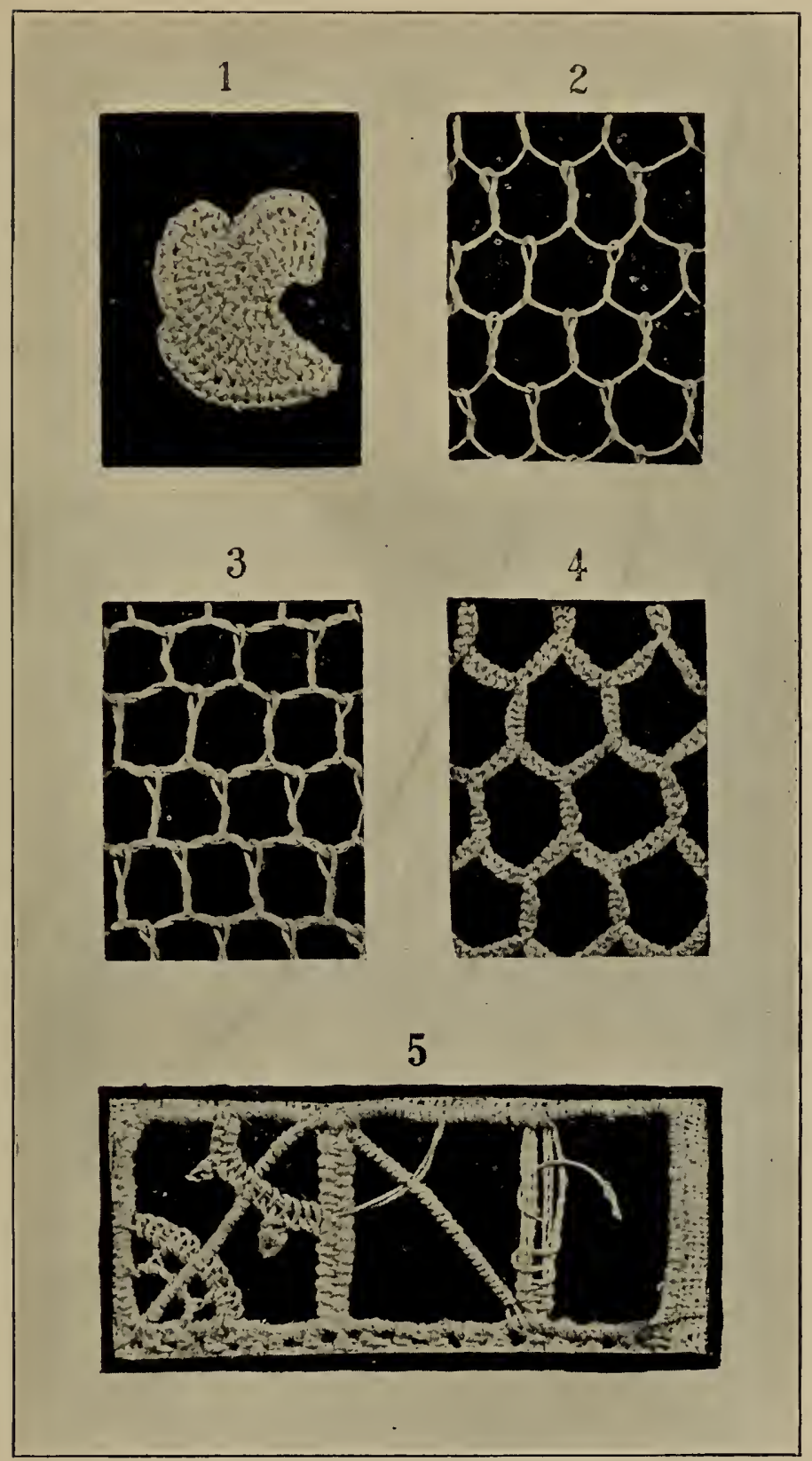

I. Toilé of Needle-point.

2. Réseau of Brussels Point.

3. Réseau of Alençon Point.

4. Réseau of Argentan Point.

5. Unfinished specimen of Cut-work or Reticella. 

DETAILS OF NEEDLE AND PILLOW LACE 5

over all along the row at the base of the meshes, as in Fig. 3, Illustration I.

Thus it will be seen that though other stitches were employed in the earlier linen lace-work, such as Drawn-work, Cut-work and Reticella (see Fig. 5, Illustration I.), yet for true Needle-point lace, with all its beautiful varieties of design and ornament, one stitch alone sufficed, namely, what we have called the looped or button-hole stitch, in Italian "Punto a festone."

Pillow lace, when carefully examined, will be found to be constructed in a fundamentally different manner. The "toilé" will in every case be seen to be composed of threads crossing each other more or less at right angles, and in and out like the texture of cambric or other woven cloth. This is shown in Fig. I, Illustration II.

The "brides," when made on the pillow, consist of twisted or plaited threads, and the "picots" of simple loops; it should, however, be remarked that "brides" worked with the needle are often added to Pillow-made lace, which is then called "Mixed lace," and in that case they will be seen to be made of button-hole stitch as above described.

The "réseau" work of Pillow lace is much more varied than that of Needle-point; the specimens 
given in Illustration II. by no means exhaust all the varieties, though the peculiar "réseaux" of the bestknown Laces are there given. They will be described in connection with each kind later on. It is sufficient here to say that in all Pillow lace the network is made by twisting and plaiting the threads, sometimes in twos and sometimes in fours, as the case may be. Thus, roughly speaking, the broad difference between Point and Pillow lace is that the first is worked throughout with looped stitches, and the second is made with twisted or plaited threads, which last is in fact weaving, though the work is done with the hands and bobbins and not with the loom. Theoretically the difference as here stated is very simple, yet it must be allowed that practically in the case of very fine Lace it is not always at first sight easy of detection, and for a beginner at all events it may be often difficult to recognise the above-described details except with the aid of a magnifying glass; when once these are seen, however, it should be easy for anyone to make the distinction between Pillow and Needle-point lace, and also, following the further descriptions given later on, to identify any special specimen. What has been said above does not apply to Darned netting, which, being usually coarse, does not require special description here. 


\section{DETAILS OF PILLOW-LACE,}

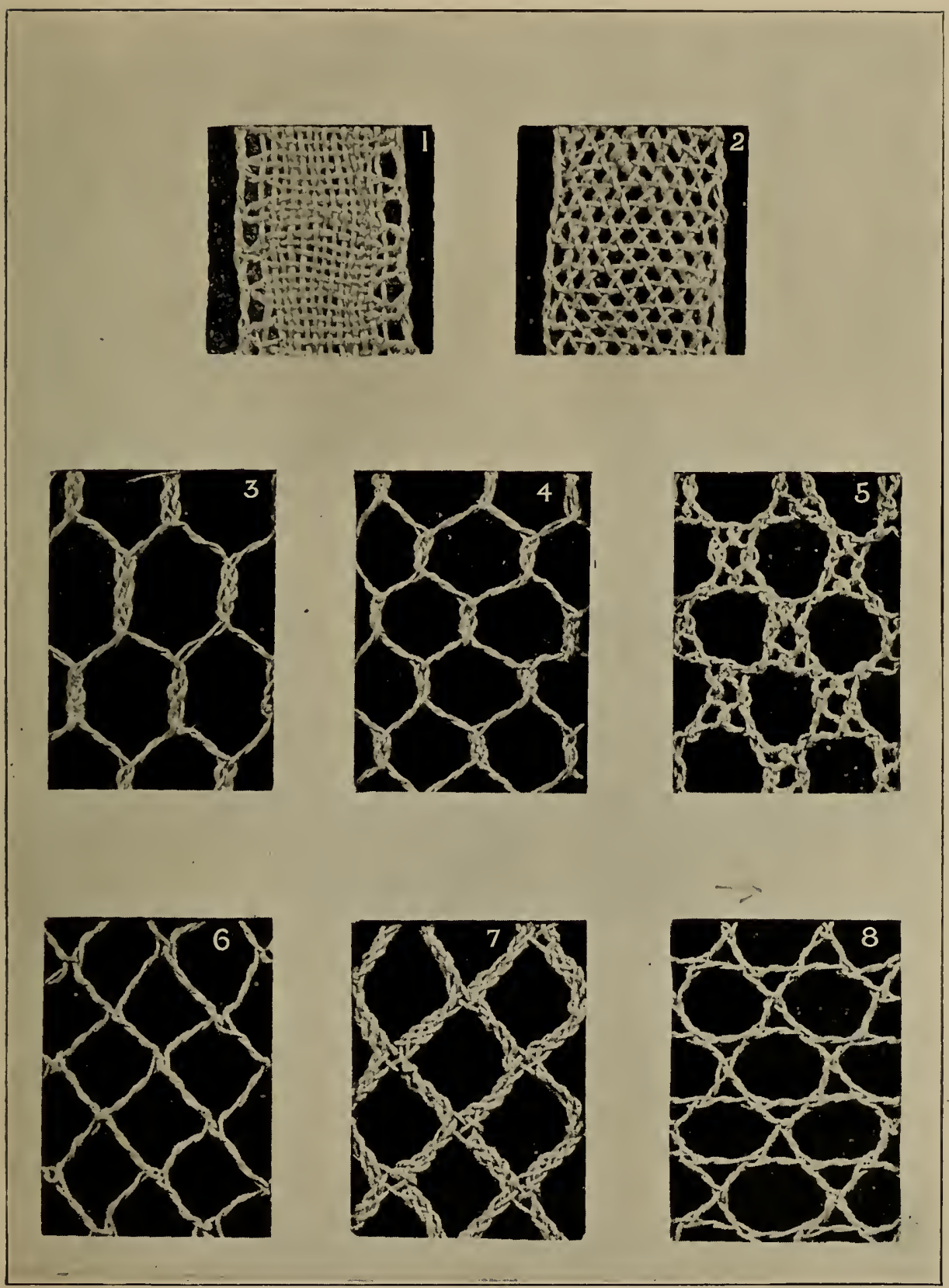

I. Toilé of Pillow-lace.

3. Réseau of Brussels Pillow-lace.

5. Réseau, called "Cinq Trous."

7. Réseau of Valenciennes.
2. Open Toilé of Brussels Pillow-lace.

4. Réseau of Mechlin.

6. Réseau of Lille.

8. Réseau, called "Fond Chant" or "Point de Paris." 

Having been able, with some confidence, to identify any particular specimen, whether it is Point or Pillow lace, or Venetian, French or Flemish in style, the further question is often asked, "How old do you think that piece of Lace is?"

There are several indications that will help to answer that inquiry. We know of certain styles of Lace that they were invented at a certain time, and that they were worn during certain periods, and in this connection contemporary portrait art is of great service and interest. Moreover, it is generally found to be the case that the style of design at each centre of the lace-making art went through a definite and very easily traced course of development. The Lace made at Alençon or Mechlin during the seventeenth century, for instance, was very noticeably different in the style of the patterns from what was produced in the eighteenth century, and it was the same elsewhere. In fact the same laws seem to have governed Art in every direction, and as Architecture passed through various styles which can be recognised and apportioned to different periods, so also in its degree did the Art of lace-making.

In the illustrations given further on the carefully selected representative collection of the various styles will, it is hoped, be found useful in assisting C 
the student to classify any Lace that may come under notice.

Yet the matter, it must be confessed, is somewhat complicated by the fact that some styles of Lace continued to be produced during long periods of time, even after later fashions were developed. Cut-work in particular was made with very little, if any, change in the style of design during two or even three centuries; and in the case of the simpler kinds of Pillow lace, the parchment patterns on which it was made were often treasured and handed down from one generation of lace-workers to another; one family, from mother to daughter, confining themselves to working a few patterns only, which they naturally continued to make as long as there was a demand for them. This is the case at the present day with the manufacture of modern Valenciennes at Ypres and in the neighbourhood. But with these exceptions a study of the construction and style of design of any particular piece of Lace should afford a fair indication of the date of its production.

No indication has been left us to show that what we now call Lace was known at all in Greek and Roman times, and it is rather curious that the fable of Arachne turned into a spider because she rivalled 
Athene in the delicacy of her needlecraft should have been invented, when no such work as could be said to approach to the fineness of a spider's web was practised till so many centuries later.

Lace, as we now understand it, belongs, like music, essentially to modern times; and taking into account its extreme fragility, it may be said that probably no Lace now existing is older than three hundred years, and that but little of such fine or open Lace as can be used for articles of dress is more than two hundred years old.

The earliest supposed record existing of its practice is in a picture by Quintin Matsys in the church of St. Peter Louvain (date I495), in which a girl is represented working at a lace-pillow, though it is not possible to identify the kind of Lace upon which she is engaged. Until the middle of the sixteenth century, that is before the reign of Queen Elizabeth, in England at all events, Lace as applied to dress does not appear at all in the portraits of the day. The ladies of Henry the Eighth's court, painted by Holbein, wore plain linen head-dresses and untrimmed frills at the neck and wrists.

It is interesting in our National Portrait Gallery to be able to see almost the exact time of the introduction of this beautiful Art. Queen Mary 
Tudor, as there represented, though handsomely dressed, wears linen cuffs embroidered but bare of Lace, not yet then in use, but in the picture next to her in date, already a little lace edging appears round the ruff, and in the portraits of Elizabeth and her courtiers ruffs and Lace together have grown rampant.

And if we cannot attribute a very early date for the invention of the Art of lace-making, neither was it in its perfection of long duration; it suffered much from the rage for simplicity born of the doctrines of J. J. Rousseau in the eighteenth century, and was practically extinguished by the troubles of the French Revolution and by the classical fashions in dress which succeeded them under the Empire.

In France the manufacture of rich Needle lace has to some extent recovered itself. Within the last fifteen or twenty years also great efforts have been made to revive the Art in Venice, and schools have been established in the island of Burano in the neighbourhood. In Belgium neither needle nor pillow lace-making were ever, even in war time, altogether discontinued, but the character of the Lace has been essentially altered. Owing also to the increased cost of labour, such modern Lace naturally commands very high prices, and nowadays 
when the genius of the inventor has so marvellously perfected the achievements of steam machinery in lace-making, and when such Lace can be bought at astonishingly low prices, it is scarcely to be expected that any real or considerable revival of the Art should take place. All the more, since the exquisite work of former ages is thus practically irreplaceable, must we value such of it as has been preserved to us, with the interest of antiquarians, as well as on account of its intrinsic beauty.

The chief centres of Needle lace-making were Venice, Brussels and Alençon. Of Spanish-point, so called, some may have been made in Spain, most however that goes by that name was certainly Venetian. The Greek Lace, which is a Cut-work of geometrical design, though it has often been bought in the Ionian Islands, was also probably Italian.

Pillow laces of some sort were, at some time or another, made all over Europe, but nowhere else did they attain to such beauty as in Flanders, where, according to some, the Art was invented.

Of Italian laces there are both Needle-point and Pillow. The former take the precedence in date and also in point of beauty; the latter came chiefly from Genoa and the districts in North Italy, as also the varieties of knotted and plaited Laces to be described later on. 


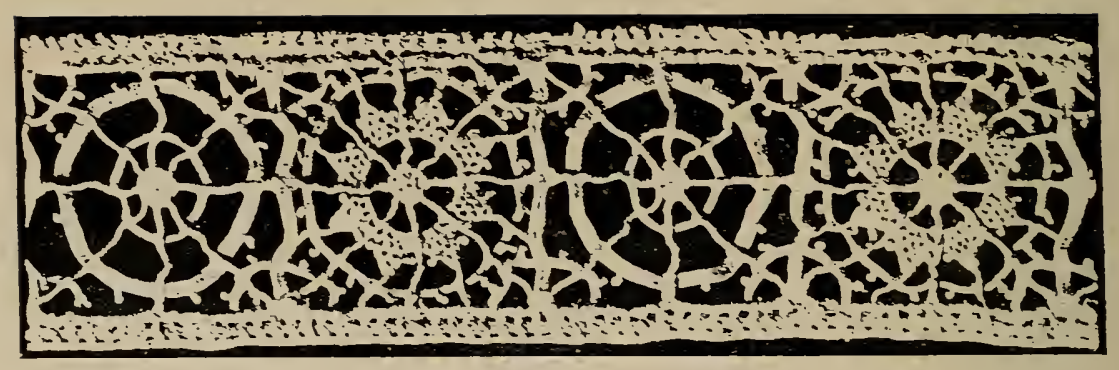

Reticella.

CHAPTER II.

\section{OF ITALIAN NEEDLE LACE.}

Is point of design Italian Lace may be classed under four styles: the Mediæval, the Geometrical, the Renaissance, and the Rococo. Such as belongs to the two first was for the most part worked out of linen and often combined with embroidery. The material spun with the old-world distaff, as still to be seen in the country districts in Italy, and woven under no great pressure of haste on hand-looms in the convent or the cottage, was far superior to anything that can be now procured in purity and strength. It was unmixed with cotton, that cheaper substance which so detracts from the durability and quality of our modern linen manufactures. The specimens of 
church and household linen preserved to the present day bear sufficient testimony to the good workmanship of the weaver and the excellence of his materials.

The Lace included under the above-mentioned two earlier styles, namely, the Mediæval and the Geometrical, are Drawn-work, Cut-work, Reticella or so-called Greek Lace, and Lacis or Darned netting. They were produced chiefly during the sixteenth century.

The third or Renaissance style expressed itself in flowing patterns of scroll work, and in a conventional treatment of flowers and other objects. The Lace was worked entirely without a linen foundation. Of this description are all the most beautiful achievements of the Art in Italy during the seventeenth century, namely, the splendid Venetian and so-called Spanish-points.

Lastly came the Rococo style, when boldness and beauty of design were sacrificed to complexity of detail, and when natural objects, and especially flowers, were represented with small regard to symmetry or unity of composition, but often also with marvellous skill and fidelity. The Lace produced during the early part of the eighteenth century in this style, in spite of an overflowing redundancy of ornament, must still challenge admiration by the beauty and ingenuity of 
the execution; but these merits rapidly disappeared, and the Rococo Lace of a later period became coarse and inferior in workmanship, while the patterns dwindled to stiff and disconnected ornaments, sparsely set in a "réseau" ground.

After this general account of the styles, as they succeeded each other, the laces themselves may be separately described.

\section{PUNTO TIRATO.}

(Eng. Drawn-work.)

This Lace is one of the earliest in point of date, and may be said to be the origin out of which all future lace-work grew. It is made entirely out of a loose linen material, the threads of which are not cut or pulled out, but merely drawn apart from each other and closely sewn over, either with silk or linen thread, thus having the appearance of a network of small square meshes, which forms the ground of the pattern left in the plain linen. The design thus grounded was of necessity angular, but occasionally this angularity is corrected by means of a silk or linen thread embroidered like a "cordonnet" along the outline on the surface of the work. The whole is usually in the form of bands, four or five inches wide, edged with a border of the linen embroidered. 


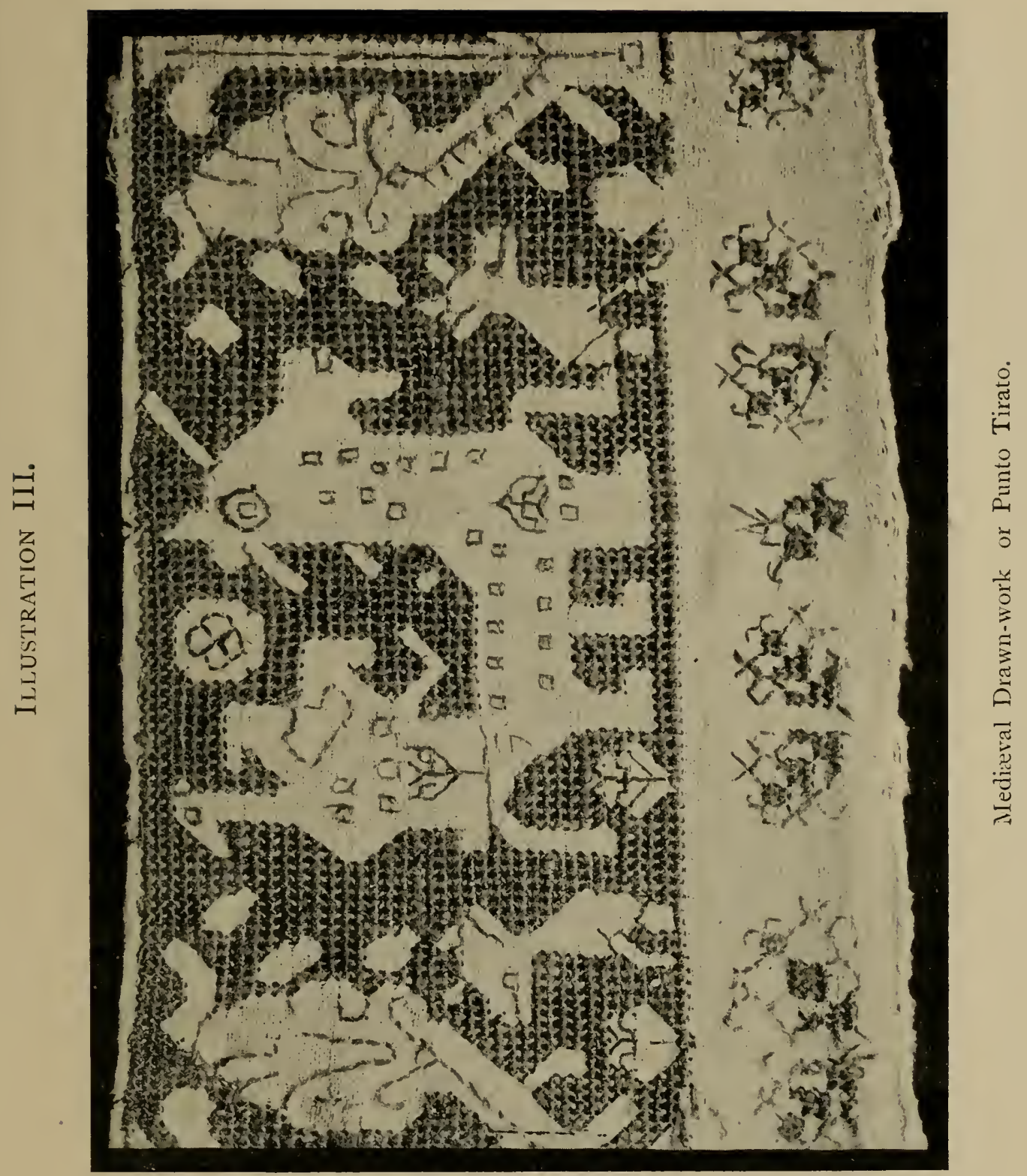



The subjects of the designs are often extremely quaint--horses, dogs, birds, besides mythical animals, were most ambitiously attempted, as is shown in Illustration III. The frequency with which representations especially of horses occur reminds one that they are to this day the favourite subject of popular Art in Venice, where the real animal can never be seen, and suggests a Venetian origin to these designs. But work of the kind was also extensively produced in Spain, and here the designs chosen were usually Oriental in character, heavy scrolls and arabesques suggesting the influence of Moorish taste. In the Greek islands also this work seems to have been made, and in this case with strictly classical patterns, survivals, no doubt, of early Byzantine traditions. Much the same effect was accomplished by means of another kind of early Needle-work lace named-

PUNTO RICAMATO A MAGLIA QUADRA.

(Fr. Lacis, Eng. Darned netting.)

But in this work the ground is supplied by a netting of either silk or linen thread, made with knots in the usual way or sometimes with threads only twisted. The pattern is worked on the netting with a stitch like darning, and also as a variety with 
an in-and-out stitch like weaving. It appears to have been much in use for church work for sacred emblems, as the lamb and the pelican are often met with, as well as dragons and terrible imaginary beasts of all sorts. (See Illustration IV.) The work remained long in favour, and in later times really beautiful scroll-like patterns in the Renaissance style were so executed. In the South Kensington Museum Collection there are several very gracefully designed borders to silk table-covers in this work, made both of white and coloured threads and of silk of various shades. It is, indeed, surprising to see what an extremely good effect is thus produced by very simple means, and it is to be regretted that when this work was revived a little while ago under the rather inappropriate name of "Guipure d'Art," such very poor patterns should have been preferred to those of the beautiful Italian work of the kind in existence. This work has a special interest, because it introduced into the Art of lace-making the principle of the looped stitch, which is the common foundation of all netting and also of all Needle-point lace-work. 


\section{ILLUSTRATION IV.}

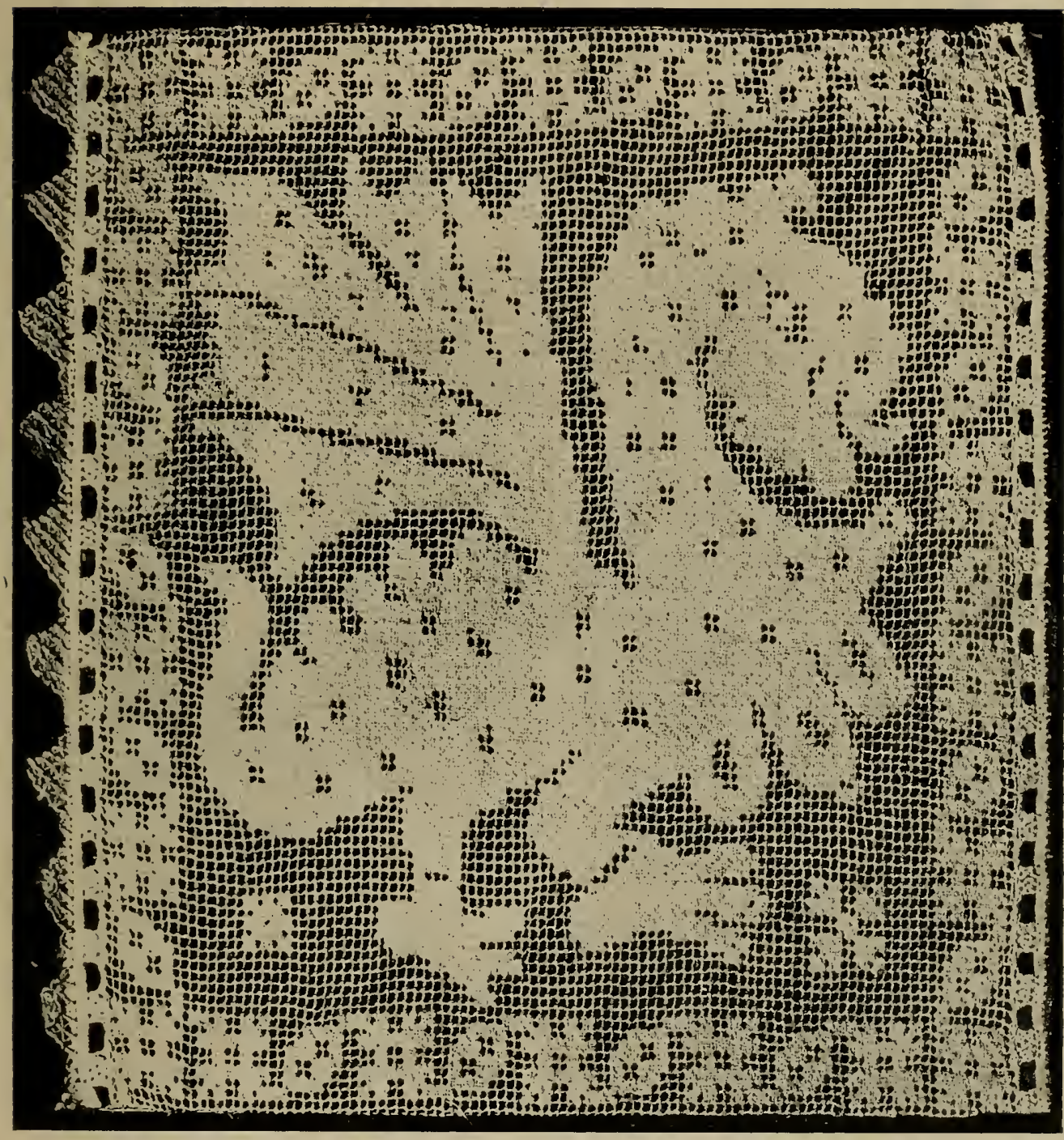

Darned netting, or Punto ricamato a maglia quadra. 



\section{PUNTO TAGLIATO \\ (Fr. Point-coupé, Engr. Cut-work)}

is an advance on Drawn-work. It is made by cutting squares or rectangular spaces out of the linen and filling them with needle stitches worked on transverse threads. In this work the patterns are geometrical, but they are varied by the rich embroidery generally worked on such plain spaces of the linen as were left. The peculiar character of this embroidery should be noticed, as shown in Illustration V.; the threads composing it are always laid parallel to either the woof or warp of the linen foundation, they are never, as in modern satin stitch, worked diagonally, nor is any padding ever used underneath the embroidery to raise it.

The construction of this kind of Needle lace will be easily seen in the unfinished specimen given in Illustration I., Fig. 5. It will be found to consist of three different stitches, a looped button-hole stitch, a close-sewn rope stitch covering one or two threads, and an in-and-out stitch over two or four threads, called in Italian "Punto di Genoa." These stitches are used in Lace worked out of linen, such as Cutwork and Reticella, and should be carefully noticed and understood if the beautiful work so called is to be 
properly appreciated. Cut-work, as well as Reticella, is often misnamed Greek Lace.

RETICELLA, OR GREEK LACE.

This Lace differs from Cut-work in that though it also is worked out of a linen foundation, the linen has almost entirely disappeared; a narrow, double hemstitched edge at the top and bottom of the band of Lace is all that is discoverable. The threads left as the framework of the pattern, dividing it into square spaces, are covered closely with stitches, and the rest of the material is altogether cut away. Into these squares are introduced diagonal lines and circles and half circles forming very beautiful and intricate combinations, and enriched with patterns in solid needlework edged with "picots." This Lace is frequently called "Greek Lace," principally owing to the fact that during the English occupation of the Ionian Islands a great deal of it was found there and bought by English visitors. There seems little doubt that it was both made and largely used in Corfù and the neighbouring islands, but it is nevertheless undoubtedly Italian and not Greek in its style and origin. It must be remembered that during the time of its production these Greek islands were in the possession of the Venetian Republic, colonised 


\section{Illustration V.}

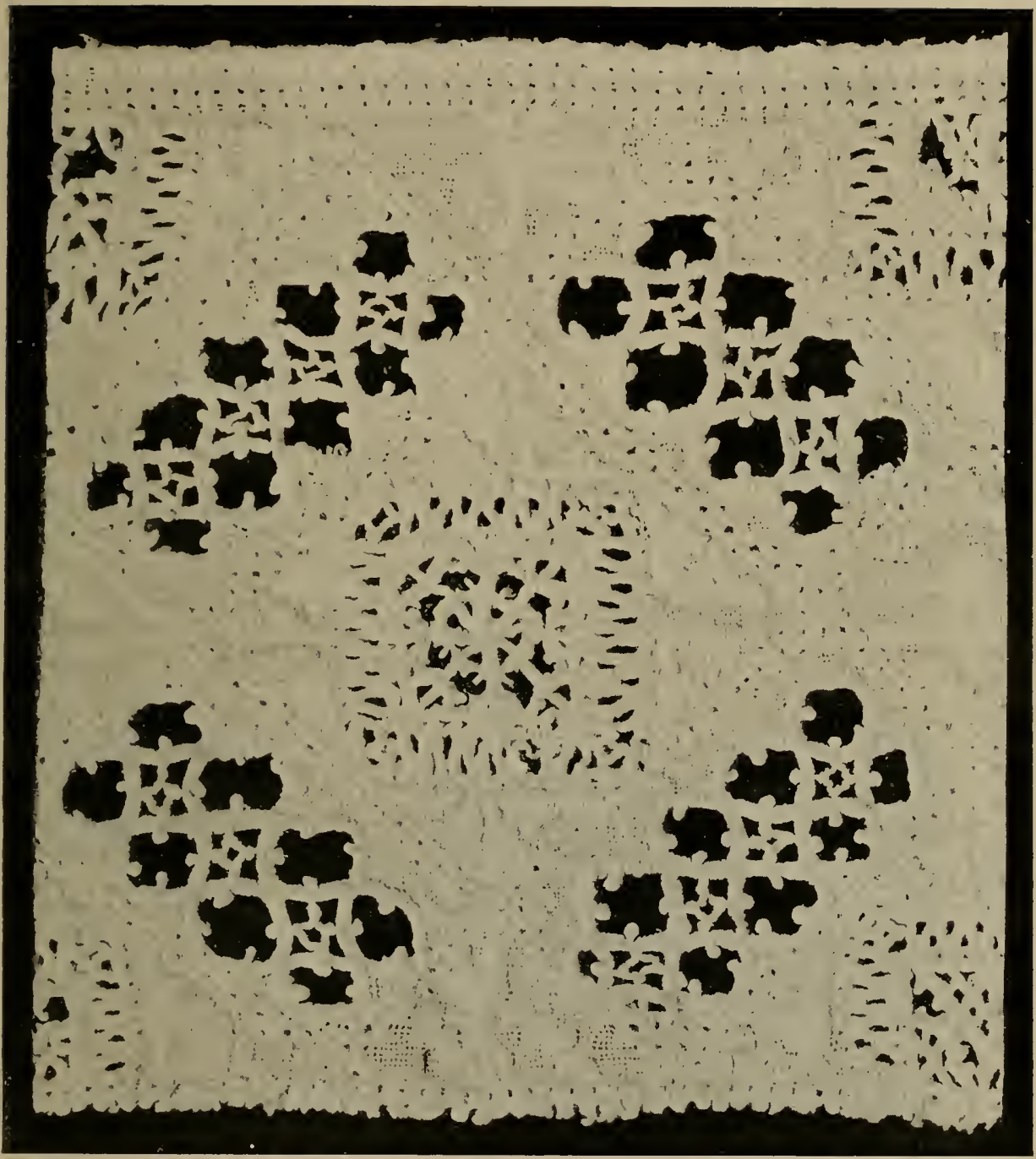

Cut-work, or Punto tagliata. 

by Venetians and in constant communication with the mother city; it is not therefore surprising that this Italian Lace should have been imported, imitated and have become naturalised there. At any rate there is no distinctive character either of pattern or execution by which the Lace, even though bought in the Ionian Islands, can be distinguished from Italian Reticella.

The Needlework laces of different kinds described in this chapter, though in use during the fifteenth and the early part of the sixteenth century, were not employed for decoration of dress. It is true that of Lace so used mention is found in records dating as far back as the coronation of Richard the Third, but such Lace seems to have been of silk or of gold or silver, and would be what we should now call braid. It may be remarked that the word Lace has survived to the present day in this sense, the gold and silver braid now used for uniforms being still so called.

Cut-work and other linen Laces were used to decorate church and household linen of every kind. During the long leisure of convent life skilful hands were continually employed in providing for the adornment of church furniture with needlework both of silk and linen thread, and almost universally in well-to-do households the ladies of the family took 
pride in seeing that their household linen was ornamented in the same manner. Tablecloths, sheets, pillow-cases and towels made usually of home-spun linen were worked with borders of this kind, a practice which, as is well known, has continued, especially on the Continent, till within the present century. All this, however, now belongs to the past; the Lace has been bought up by the ubiquitous modern tourist after having been cut off in strips, for sale, from the linen out of which it was made, and but little of it now remains in its original condition to explain the purpose for which it was worked. Yet the linen-made Laces of Reticella and Cut-work are singularly well suited for the decoration of table and especially of church linen, and it is surprising that among all the many modern sorts of fancywork these have not found more frequent imitators. The stitches are, as has been said, very simple, and the work is not too fine for ordinarily good eyesight. The Lace when completed is so good and rich in effect, and so strong for wear, that it can but be wished that fashion will some day inspire industrious and neat-fingered English needlewomen to emulate the beautiful performances of Italian ladies of the sixteenth century. 
ILLUSTRATION VI.

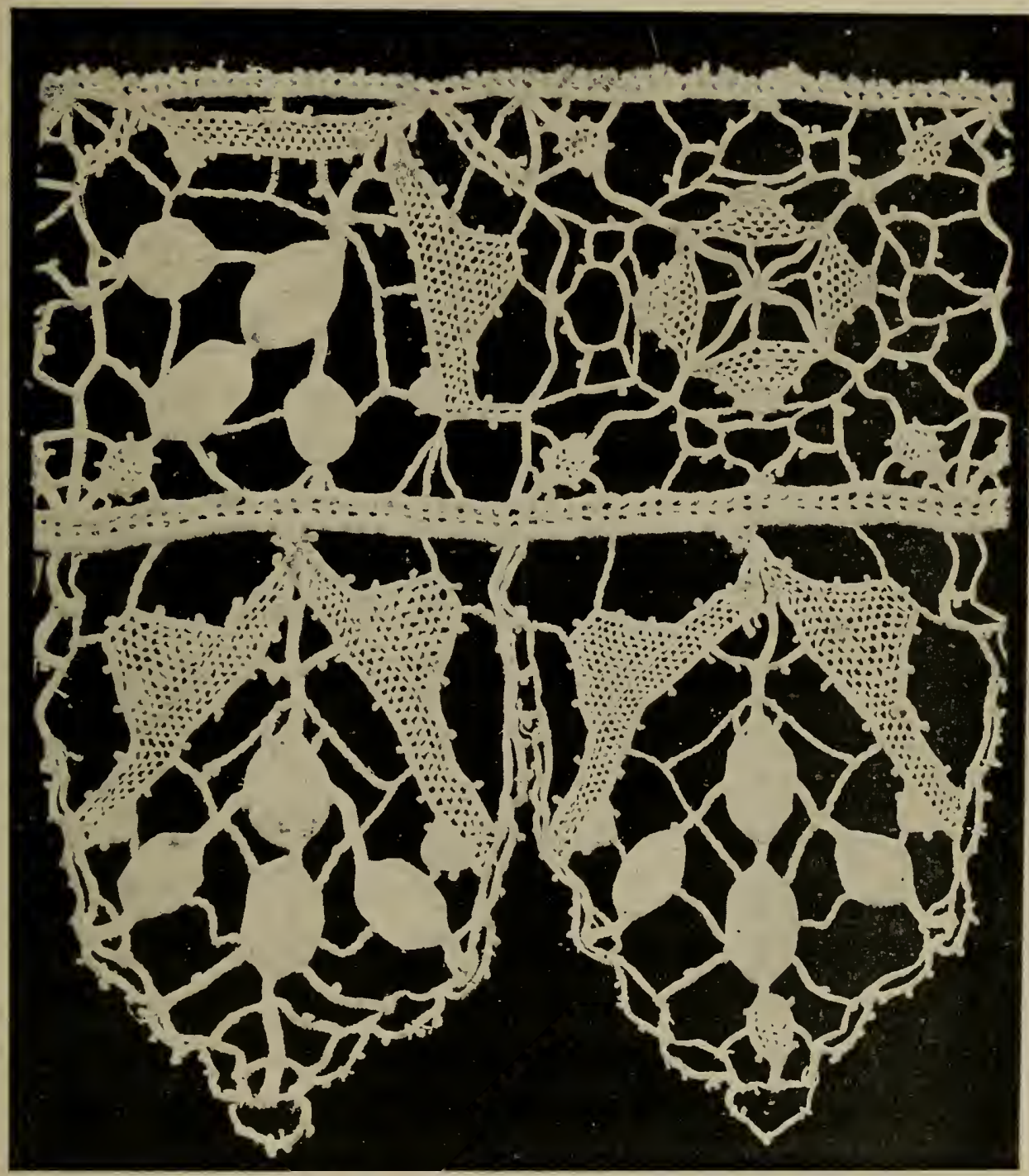

Reticella with Punto in Aria border. 



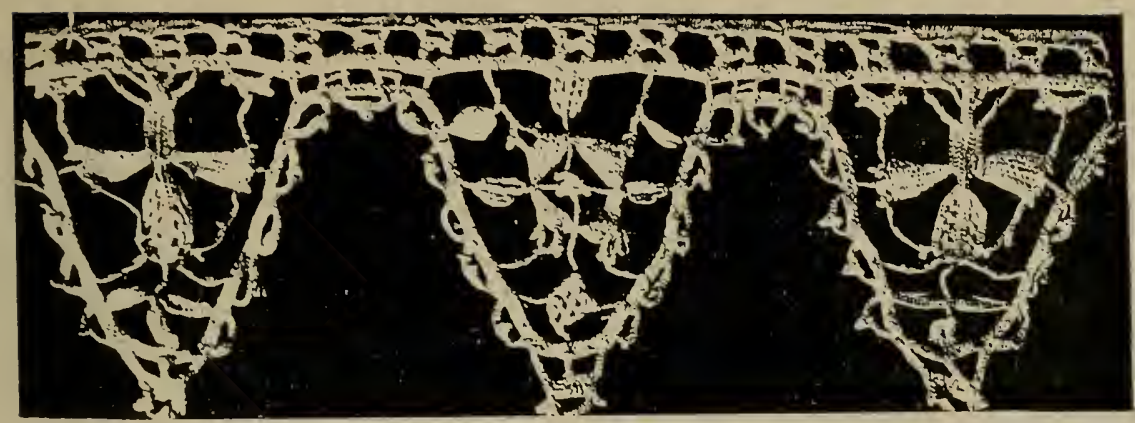

Punto in Aria.

CHAPTER III.

\section{OF ITALIAN NEEDLE LACE.}

(Continued.)

A TIME came when the restraints imposed on design by the linen foundation were found to be irksome, and it occurred to some innovator to dispense with it altogether and to construct the pattern on threads fastened on parchment in any form that fancy might dictate. This was the beginning of "Punto in Aria," literally "stitches in the air"; that is, without any foundation of linen; and it was by development of this principle that all the subsequent beautiful Needlepoints of Italy were made.

At first geometrical forms, which had been of necessity in Cut-work, were still adhered to, though 
a greater variety of ornament was found possible. Then a pointed edge was worked on threads laid down in the required shape, and the spaces were filled in with patterns of solid or open-work loop stitching executed in an excellent manner, and "brides picotées" were added to connect and strengthen the parts.

A specimen is shown in Illustration VI. of two squares of Reticella with "Punto in Aria" vandykes attached. The Reticella will be seen to be bordered by a narrow double line of hemstitch, showing that it is worked out of a piece of linen; but the vandyke is independent of such foundation. The open Medicis ruff and the cuffs worn by the little Princess of Mantua, as seen in the frontispiece, are of the same kind, namely, a band of Reticella edged with the "Punto in Aria" vandykes. The date of the picture is about I6oo.

This introduction of "Punto in Aria" marks a very considerable development in the uses to which Lace was applied. No sooner did this new style of Lace appear, as we may judge from the portraits of the day, than it seems to have taken the world of fashion by storm. Plain linen collars and headdresses were relegated to widows and waiting-maids, and Reticella, hitherto only found serviceable for 
coarse table-linen, was, in combination with the new edging, and worked in fine lawn, lavished upon cuffs and aprons and the ruffs that grew to the preposterous dimensions with which we are familiar in the pictures of Queen Elizabeth and her courtiers. These were worn both round and also of the open shape shown in the frontispiece; both shapes seem to have been in fashion together, judging by the well-known picture by Marc Gerrardo representing the state progress of the Queen on her way to pay a visit to Lord Hunsdon, and in which she is surrounded by the ladies and gentlemen of her court, the former wearing some one shaped ruff and some another. This picture was engraved by Vertue, and is of great interest as a record of the costumes of the time.

Of Queen Elizabeth's ruffs much mention is made in the lists of new year's gifts that she was in the habit of receiving from her courtiers. Besides gold and jewellery from the gentlemen, and embroideries, silks, and gifts of all sorts from the ladies, these latter presented her yearly with " ruffes with rabatines of lawne cut-work" and sets of cuffs, both made and unmade; sometimes the "lawne cut-work" was set with seed pearls, and sometimes edged with gold, or silver, or Bone, that is, Pillow lace. For the ruffs, 
one cannot but wonder at the skill of the starcher who, even with the aid of a wire frame, could stiffen so large a surface of such delicate materials so as to make them retain the required shape even for a few hours of a damp English day. But it is on this account that we have now to depend almost entirely on the pictorial art for our information about them. Starch and constant wear have been too much for the fine "lawne cut-work," and lace-trimmed ruffs have, with scarcely any exception, long since perished with their wearers.

It is at this point that the large collection of pattern books which have been preserved to us from the sixteenth and seventeenth centuries are of great interest. They became possible after the art of printing became popular, and they range in point of date from the Livre nonveau, published in Cologne in I527, to the Méthode pour faire une infunité de desseins par le Rev. Père Sebastien Truchet, published in Paris in 1722.

A list of these books, preserved in various European libraries, is to be found in the Appendix to Mrs. Palliser's History of Lace. A few original copies are in the National Art Library, South Kensington, and a considerable number of such as were of Venetian origin have been recently re- 
produced in modern facsimile editions by that energetic publisher, Signor Oncagnia, of Venice. These can be seen and studied in the library of the British Museum, so that this interesting subject is now brought within easy reach of the English student.

The earliest of these books refer to embroidery in gold and silver and silks, as well as in thread. In I 548, one published in Venice by Mathio Pagan, Il specchio di pensieri delle belle e virtudiose donne ("the mirror of the thoughts of beautiful and virtuous ladies"), gives patterns of "punti tagliati," "punti gropposi e punti in Stuora"-Cut-work, Knotted-work, and Embroidered netting. Ten years later, in 1558 , the same author brought out La gloria et l'honore di punti tagliati e punti in aere ("the glory and the honour of Cut-work and Open-work"). And this allusion to "punto in Aria" is very interesting as fixing the date of the introduction of so important an innovation in lace-making.

The early style of these patterns is narrow and wiry, corresponding closely to the edgings of the frills shown in contemporary pictures; but soon the designs become richer and wider, and being worked in finer thread than that formerly used for the old linen lace-work, and combined with bands of 
Reticella, produce a very handsome as well as light and open effect.

In James the First's reign some concession was made to comfort, and the same fluted and starched ruff was allowed to fall towards the shoulders instead of standing out round the head; then suddenly the full frill gave way to the "Col rabattu," the large falling collar with the lace border of Charles the First's time so familiar to us in Vandyke's portraits of that monarch.

$\lceil$ But to return to "Punto in Aria" and its developments. The various Laces which owe their invention to this origin are known to us as Point lace. The great distinction between them and the Lace we have hitherto considered is that Point lace is worked with button-hole stitch alone (in Italian, "Punto a festone"). In the preceding Laces, as shown in Illustration I., Fig. 5, sewing orer, rope stitch, and the in-and-out stitch called "Punto di Genoa" are also used, but in the later Point lace these are discarded and the Lace is made entirely with button-hole stitch, close or open. All the beautiful and varied effects we so much admire are produced by this alone.

Lace so worked had its origin and chief centre in Venice, and it is to be remarked that like our own English manufactures, it was brought to perfection 
not by any State encouragement such as government schools or protective duties, but rather in spite of sumptuary laws, and by the enterprise and artistic instincts of private citizens. It culminated in the splendid Lace known in French and English by many names, but called in Italian collectively "Punto tagliato a foliami," or simply "Punto di Venezia."

This Lace had an astonishing success in Italy and also in Spain and France. In the latter country especially enormous quantities of it were lavished on the dress both of men and women. Owing, as it is said, to the long curls of the young King Louis the Fourteenth, falling collars had gone out of fashion, ponderous wigs were worn by the courtiers in imitation of the King's natural locks, and, to suit the new style of coiffure, cambric neckties with falling ends of the richest Venetian Point lace were adopted. And not only so was this Lace used, but the gentlemen's sleeve cuffs, the ends of their waist scarves, the canons or frills half a yard in width which finished the short breeches of the day, the rosettes of their shoes, and even the tops of their high leather boots, were most inappropriately decorated in the same manner.

The ladies wore the beautiful "Punto di Venezia" on their caps, their sleeves, and their aprons, besides 
using it, as we see in contemporary pictures, to trim their dinner table-covers and pillow-cases, and even as coverlets for their beds, where, it must be remembered, they used to hold receptions of their friends, male and female. For church purposes it was also largely used. There is a superb altar frontal at the South Kensington Museum made entirely of Venetian Point, and in a case close by it a cardinal's alb of pleated linen, trimmed with a flounce half a yard in width of the finest "Punto tagliato a foliami," or Rose Point.

In England we have the evidence of the actual Lace worn by Charles the Second himself-and it is still preserved on his funeral effigy in IVestminster Abbey - to prove to us that the finest Venetian Point was also in fashion here. The Lace is very beautiful, now mouldering away into dust and ashes together with a truly strange collection, mementoes of bygone rank and splendour.

Venetian Point is variously called Raised Venetian Point or Gros Point de Venise, also Rose Point, Carnival Lace, Cardinal's, and sometimes even Pope's Point, Point Plat de Venise, Point d'Espagne or Guipure, and all these names have been used somewhat indiscriminately. For the two last Guipure denotes Lace made with braid, or tape, or gimp. and is not in any way applicable to fine Needle- 


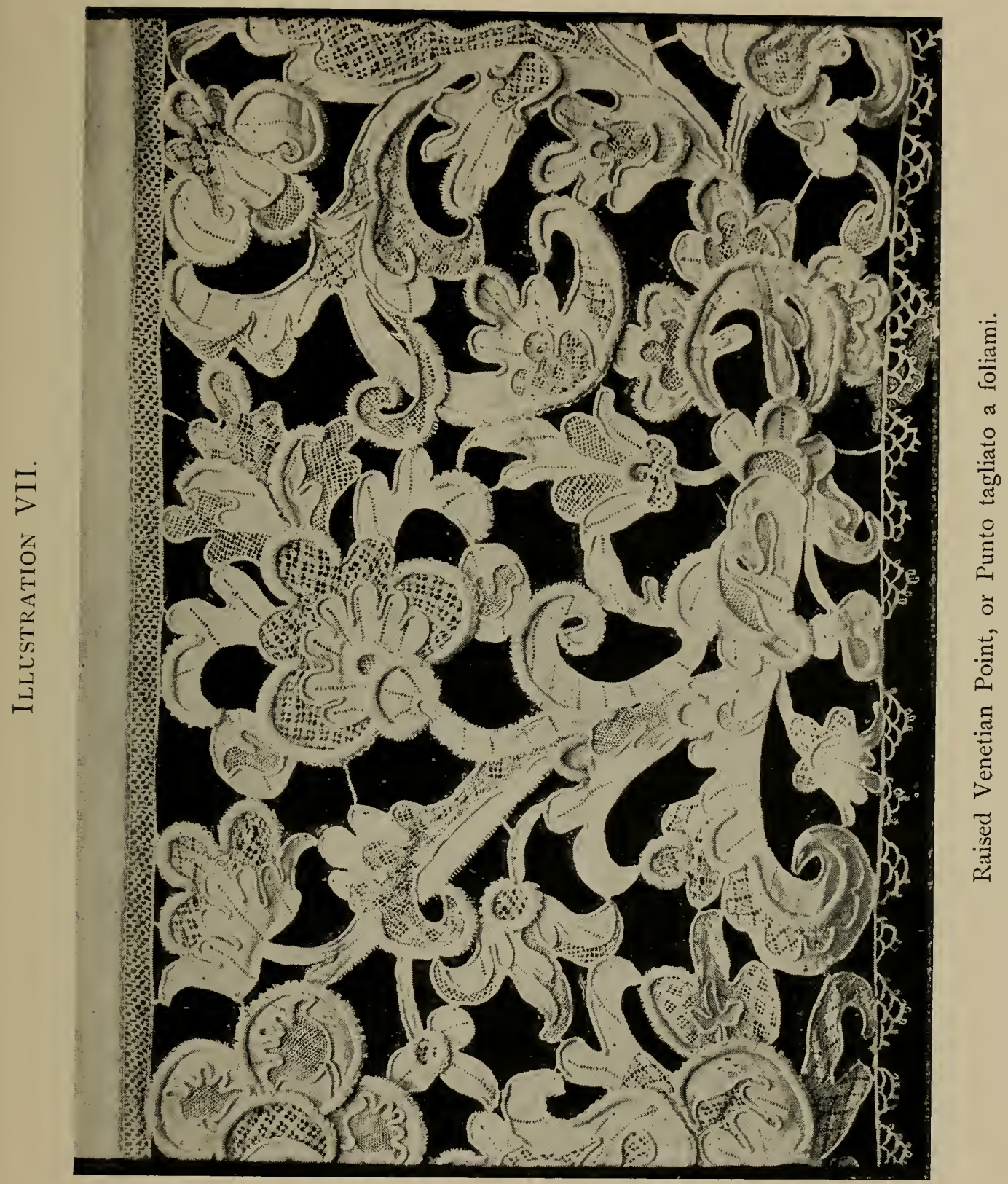



point. Point d'Espagne is clearly a misnomer for work which, though it may have been occasionally produced in Spain under Italian influence, was certainly of Venetian origin. On this more will be said under the head of Spanish Lace. For the rest, as it is certain that different stages of development and decline can be observed in the history of Venetian Lace, and having explained that the names usually employed are not always clearly separable, it has been thought best here to make use only of such names as will serve to mark the distinction between three separate stages in point of date and style of the Lace known as a whole as "Punto tagliato a foliami" or Venetian Point.

We would class them thus :-

I. Venetian Raised Point (Fr. Gros Point de Venise), under which head we include the variety called Rose Point.

2. Venetian Flat Point (Fr. Point Plat de Venise), with its later variety which, from its appearance, we would call Coraline Point.

3. Grounded Venetian Point (Fr. Point de Venise à réseau), and in this class we include "Punto di Burano," so called from the island, near Venice, where it was made; the last and final stage of the Art at the close of the eighteenth century. 
RAISED POINT, OR GROS POINT DE VENISE.

The principal distinctions of Raised Venetian Point are: First, the boldness and continuity of the designs, which sometimes extend throughout a whole piece of Lace; Secondly, the "cordonnet," which is very prominent. It is thickened in parts by the addition of sheaves of thread closely overcast with button-hole stitches, and often edged with rows of "picots." The Lace is held together by "brides," but only so far as is necessary for strength, the "bride"-work forming no essential part of the general design. The splendid specimen reproduced in Illustration VII. is in the South Kensington Museum, and forms part of the unrivalled collection of Lace bequeathed to the nation by the late Mrs. Bolckow. Such Lace has been fitly called the crowning triumph of the work of the needle. The freedom and beauty of the design are as remarkable as the exquisite delicacy and variety of the details and the perfect skill of their execution. An Italian poet is said to have described such work as "scolpito in relievo" (sculptured in relief). The words remind one that Venetian Lace in its prime was produced when manual skill had reached its highest point and went hand in hand with the heaven-born instinct of beauty; when, in fact, the 


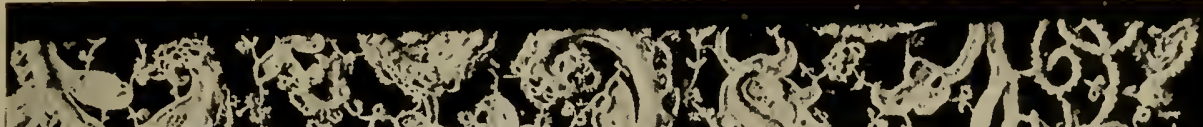

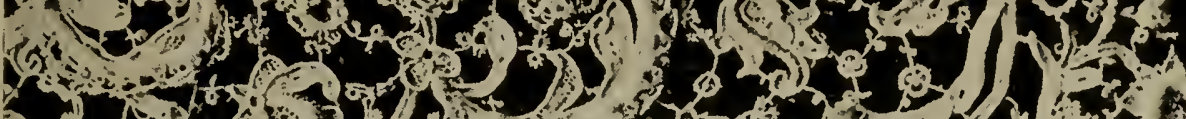

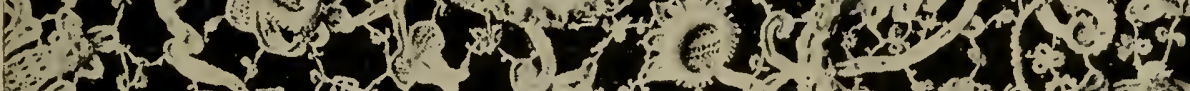

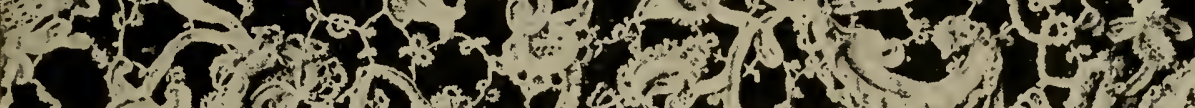

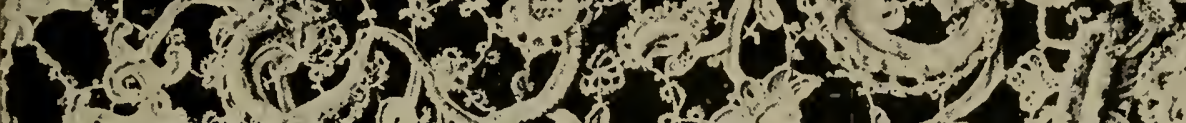

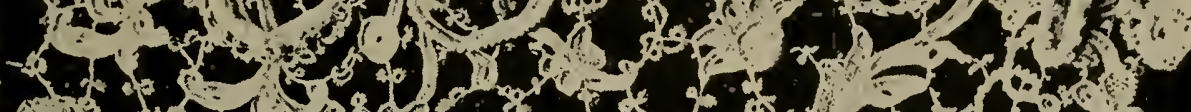

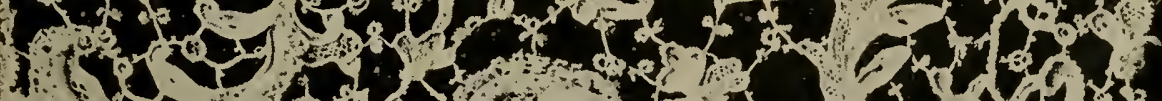

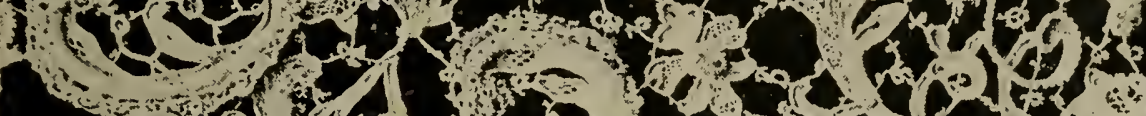
$\rightarrow+140 \mathrm{~T} x=0$

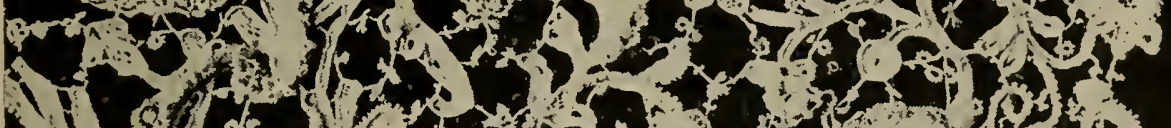

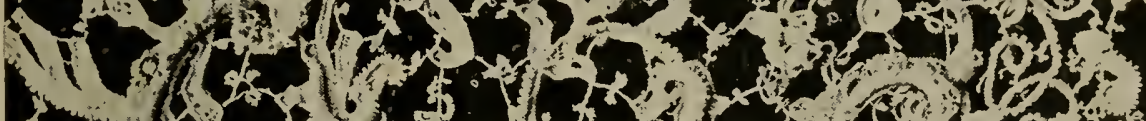

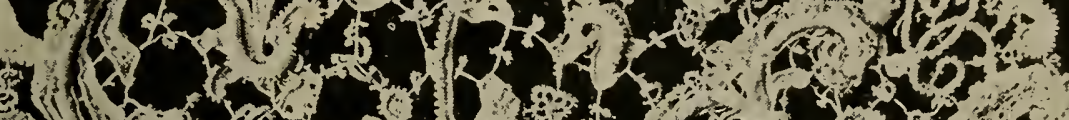
ofer

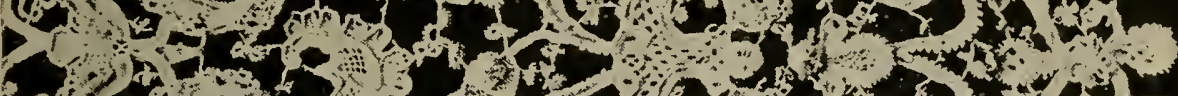

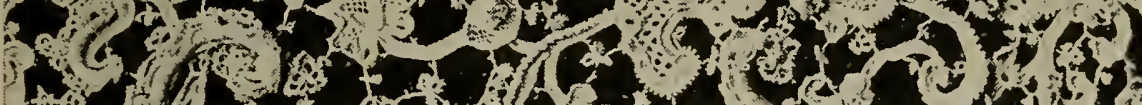

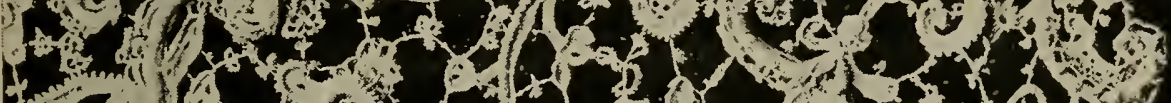
7 for

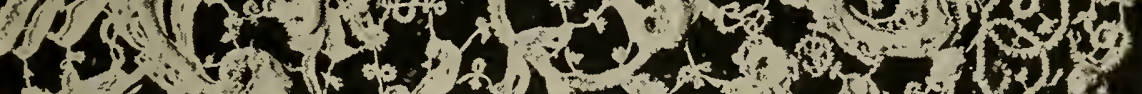

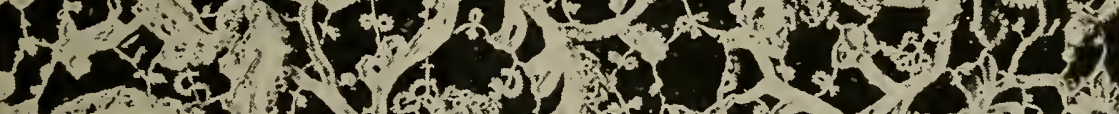
(n)

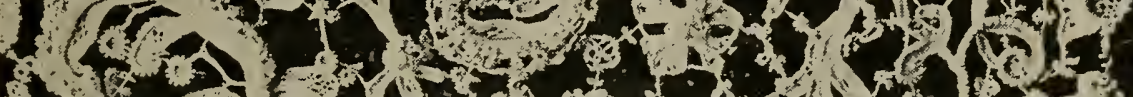
(1)

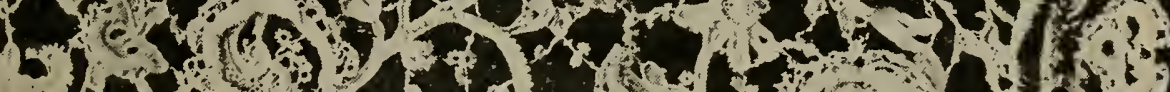

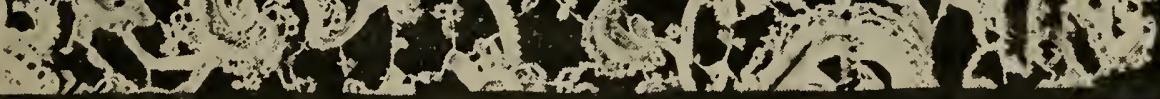



spirit of the Renaissance had infused life and vigour into every form of Art throughout Italy, and when the workers in gold and enamel, in wood and iron, and even in silk and linen thread, were artists as well as the sculptor and the painter. Such periods are short-lived.

ROSE POINT.

The distinctions to be drawn between this and the preceding Lace are not very marked; the style is modified, not changed. The designs are composed on a smaller scale, enriching ornament is more abundant, and the groundwork of "brides" becomes a more important element in the whole effect. These are now further decorated not only with "picots" but also with numerous little whirls and rosettes, and hence perhaps the name of Rose Point. The specimen shown in Illustration VIII. is also, like the preceding, taken from the Bolckow bequest in the South Kensington Museum, and is a singularly rich example. Here the raised "cordonnet" is edged not only with one but with two and three rows of loops and "picots," till the effect produced is almost that of snowflakes, on which account such Lace is sometimes called "Point de neige." Rose Point is later in style than the "Gros Point de Venise." 


\section{FLAT VENETIAN POINT.}

The name of this Lace denotes the difference of its character. The raised work is here altogether absent, the designs, though often very graceful and well composed, as is the case with the specimen shown in Illustration IX., are more attenuated than in Raised Point, while the "brides," as in Rose Point, are an important feature in the general effect.

The manner in which the work was executed was the same in all three. The piece of parchment on which the pattern was drawn out was tacked upon some thick, soft cloth, then a coarse thread or cord was sewn down along the outline through both the parchment and the cloth together. The scroll-work or flowers of the pattern were then filled in with button-hole stitches, as shown in Fig. I, Illustration I., either close or open, and finally the "brides" were added to hold the parts of the pattern together, and when the work was completed a sharp knife was passed between the parchment and cloth to cut the stitches which held down the outline cord and so to free the finished Lace without any risk of injuring it. A later style of Flat Venetian Point is one that we venture to name on account of its strong resemblance 


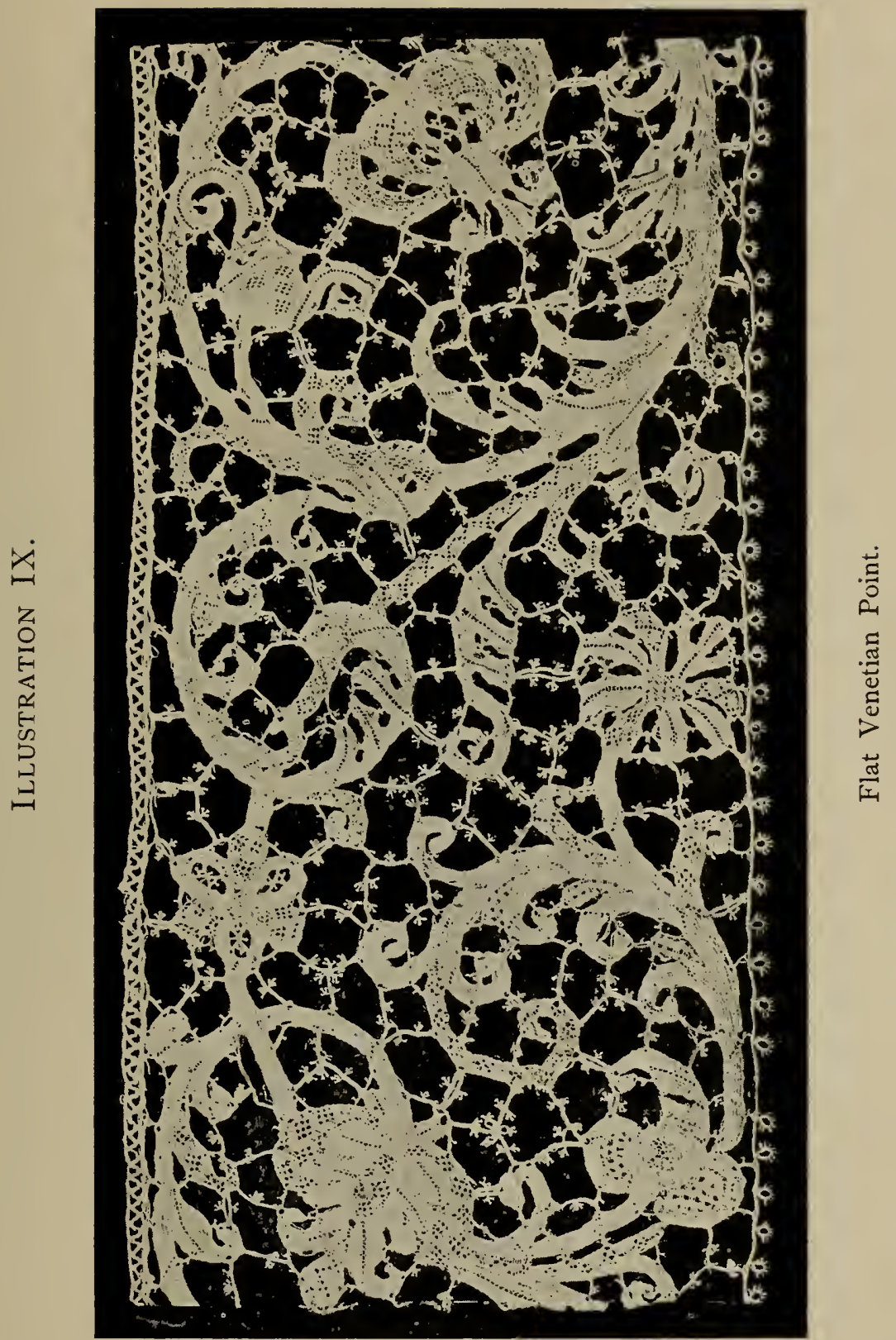



to the delicate fretwork of fine coral growths, and also because of the story that is told of its origin,

\section{CORALINE POIN'T.}

It is said that a young girl, a lace-worker in Venice, received as a parting gift from her sailor lover when he left her to wait for his return, a branch of coraline, and she, looking at it and thinking of him while at her work, considered how she could imitate it with her needle. She tried, and the result was so charming that she speedily found imitators, and the Lace became one of the most favourite in use. This Lace is often specially called "Venetian Point," and rightly so, for whereas the "Point Plat" and the "Gros Point" have been copied both in. Spain and France, this Lace, whose origin is a gift from the sea, has never been produced elsewhere than on the shores of the Adriatic. But beautiful and wonderful as it is, it must he considered as a decline from the earlier styles. Very little connected pattern is to be traced in it at all, and what there is is often shapeless and angular. There is little or no raised work; the ground of "brides picotées," though well distributed, is without method in its arrangement and the shape of the meshes. It has, in fact, the effect of a tangle-a work of nature rather than of Art, $\mathrm{H}$ 
charming for its delicate workmanship, and for the very reason of its confusion. But the finest Art has never been considered to be the mere imitation of the free growth of natural plants or animals, its object is rather to generalise and idealise nature, and to express and suggest, through the representation of things familiar to us, the higher spirit of symmetry and harmony, and that sense of ideal beauty which is the peculiar gift of artistic genius.

The third and last stage of Venetian Lace is the

\section{GROUNDED POINT.}

(Fr. Point de Venise à réseau.)

Till about the middle of the seventeenth century there was an almost insatiable demand for Venetian Lace at the French Court, and the supply seems to have been abundant; but when the manufactures of Alençon and the neighbourhood were started, encouraged by the King, and protected by prohibitive duties against the importation of Italian Lace, the profits of the Venetian lace-makers fell off considerably. It was then that, in the hope of retaining their foreign customers, they learnt a lesson from their supplanters, and in imitation of the manufactures of Alençon they adopted the 


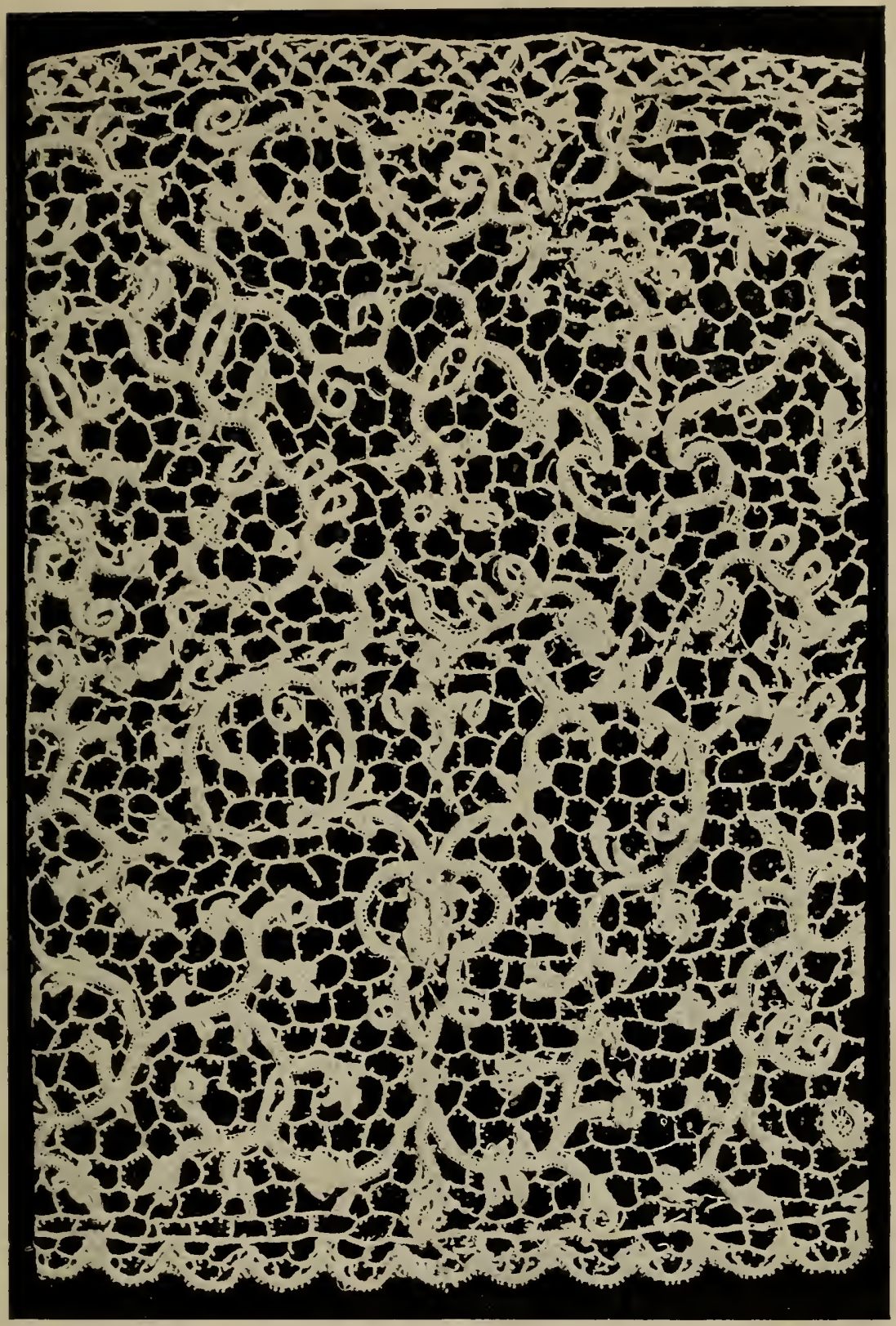

Venetian Point (Coraline), or Punto di Venezia. 



\section{IlLUSTRATION XI}

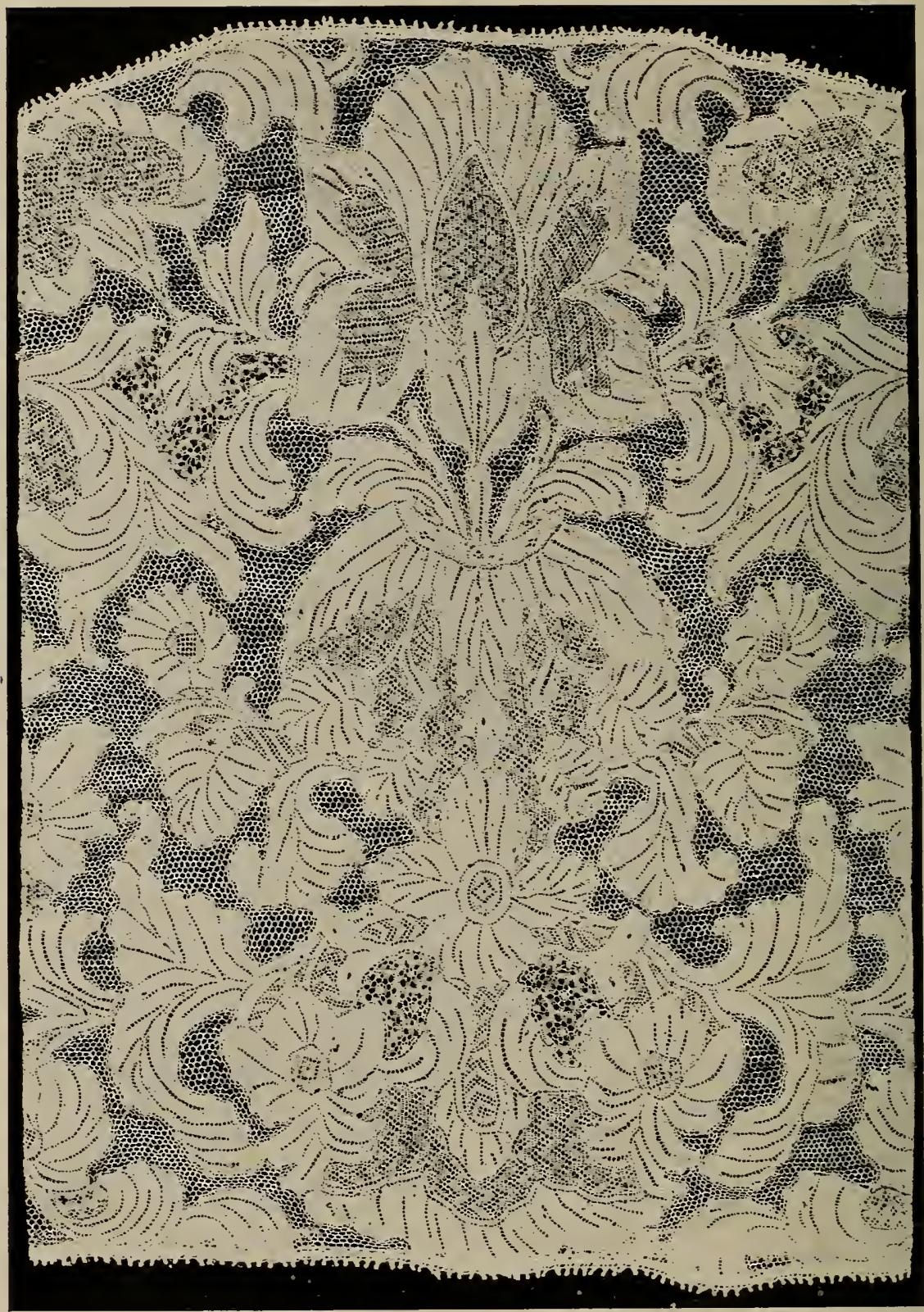

Grounded Tenetian P'oint. 
"réseau" ground. The style of the "réseau" is much the same as the French, though the mesh is rounder and does not fall into lines across the Lace as with Alençon and Burano. It is composed, however, of double twisted threads throughout, as Fig. 3, Illustration I. This Lace differs further from Alençon in that the pattern is not outlined with any "cordonnet." Venetian Grounded Point is a very beautiful piece of work, exquisitely fine, delicate and graceful (see Illustration XI.), yet in point of style it falls under the strictures passed on the Rococo period, inasmuch as it often suffers from a redundancy of ill-arranged decoration.

The variety and abundance of the ornamental "à jours" are especially to be noticed. These are far too numerous to be described, but a zigzag ornament may be specified as very characteristic. The pattern usually includes the representation of lilies and other natural flowers, and the edge of the Lace is generally in the form of a shallow scollop, arranged so as to form part of the design.

This Lace was produced during the latter half of the eighteenth century; then came the end, when the storm of the French Revolution burst upon Europe and overwhelmed the Venetian Republic in its course. Rich patrons had then to think of saving 
their lives and what they could of their property, and no longer bought Lace, and the poorer classes learnt by experience that to kill the goose who lays the golden eggs is not the way to prosperity.

Yet the manufacture survived for a little while longer in the island of Burano, near Venice, and as late as the beginning of the nineteenth century a needle-made Lace, insignificant in pattern and coarse in execution, was still made there by native workers. Mrs. Palliser, in her History of Lace, published in I 864, gives an illustration of a specimen of Burano Lace which she says had been bought of an old woman, the maker, one Ceccia la Scarpariola, the last survivor of the lace-making industry, and she adds, "Venice Point is now no more."

This same Ceccia or Cencia was still older when in 1872 an unusually severe winter reduced the inhabitants of Burano to great straits of poverty. The population was at the time entirely dependent on fishery for the means of existence, and when the canals and lagoons were for weeks corered with ice, wholesale starvation seemed imminent. Their distress came to the knowledge of a M. Paulo Fambri, who made an appeal to the charitable throughout Italy for help. The King and Queen and the Pope gave the example, and a considerable 


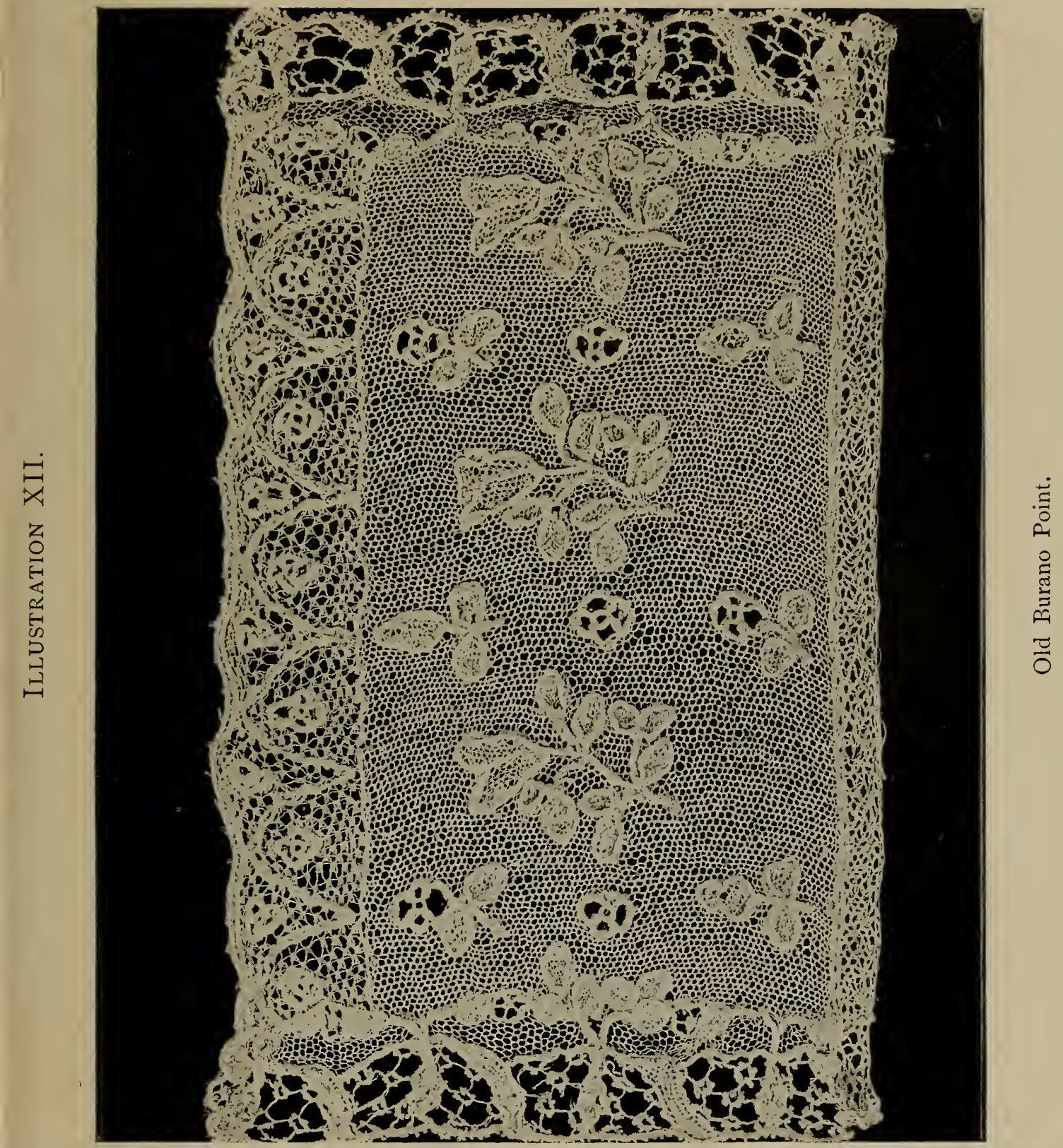



sum was raised, part of which was immediately spent in alleviating the distress, and with what remained, as a more permanent source of help and comfort to these poor people, a school was started in which it was hoped that the lost Art of lacemaking, so profitable in the past, might be revived for their benefit. Cencia Scarpariola was then seventy years of age, and was the only living person who remembered or could show how the work was done, and she, from old age and infirmity, was incapable of teaching. However, nothing daunted, some Venetian ladies, headed by the Countess Adriana Marcello, who eventually assumed the whole management of the affair, succeeded in finding an intelligent worker who could learn only by seeing the old woman at her needle, and she in turn taught others. Keeping at first to the old Burano style, and afterwards copying from patterns and designs which were most kindly lent by Her Majesty the Queen of Italy and others, the school has at length been able to produce Lace of various kinds, but little inferior to the best of the Venetian triumphs of former days.

In Needle-point lace the Burano girls now reproduce Raised Venetian Point, Point d'Argentan, and d'Alençon, and old Brussels, as well as the peculiar 
Burano Lace of their native island. Thus a beautiful Art has been successfully saved from oblivion, and as the lace-makers are able to earn what to those simple folk is very good wages, the means of subsistence of the population is very considerably increased, and comfort and good morals are the satisfactory results.

In an account of Venetian lace-making, written by Urbani Gheltof, published in Venice, and translated into English by Lady Layard, a very detailed description, accompanied by diagrams, is given of the mode of execution of Burano Point.

From this it appears that it is usually worked on a pillow, not however, of course, with bobbins as for pillow-lace. The object of the pillow or bolster is merely to raise the work to a suitable height on the lap of the lace-maker and to diminish the necessity of much handling. On the middle of the upper side of the pillow there rests a small wooden cylinder across which the parchment pattern is stretched, leaving an open space under it for the convenience of the worker; thus the strip of Lace is kept smooth and flat. In working the "réseau" ground a thread is fixed straight across the whole width of the Lace as a foundation for each row of meshes, being passed through and fastened to any 
sprig or part of the pattern which may intervene, and on this thread the looped meshes are worked. The result is the formation of a remarkably squareshaped mesh, and by this, and also by the streaky and cloudy appearance of the "réseau," Burano Point may be recognised; the latter effect is owing to unevenness in the quality of the thread. Burano also differs from Alençon in that its "cordonnet" is not overcast or covered with button-hole stitch, but is only stitched down round the outline. In the matter of design the patterns are generally, as in the illustration, small and floral, the "réseau" ground being sprinkled with leaflets or blossoms; but Alençon patterns of a late period were also often copied, so that the quality of the "réseau," and especially the heavy thread "cordonnet," should be chiefly relied upon rather than the pattern as marking the difference between the two kinds of Lace.

For the benefit of visitors to Venice it may be added that the Burano Lace schools, under the patronage of the Queen of Italy, are in the Palazzo Municipale, opposite the church in the principal Piazza in the island, and that they will well repay a visit. Lace-making can be better understood by being seen than by even the most careful of descriptions. 


\section{OF SPANISH LACES.}

These are included in the present chapter on account of the frequent misuse of the terms "Spanish Point" and "Point d'Espagne" applied to - Italian Laces. As in the case of the Brussels Lace known as "Point d'Angleterre," names may be in common use and yet not always safe guides. With regard to Spanish Lace it seems difficult to be sure of the facts of the case.

It is certain that great quantities of Lace that we should describe as Raised Venetian Point were used in Spain both for the dress of the Court and also especially for the adornment of the church vestments, altars, and images of saints. During the French invasion, when churches and monasteries were freely pillaged, these treasures were scattered over the world, and on this account, if for no other reason, were sold in the market as "Spanish Lace." But it is also probably true that Lace of the kind was made in the convents of Spain, where nuns from Italy would naturally teach and introduce an Art so much in request. To judge, however, by style where the actual nationality of the work seems doubtful, it is clear that there is no sufficient difference to mark "Point d'Espagne" as a really distinct Lace from Venetian Point. 
The Lace known for certain to be of Spanish production is a coarse pillow Guipure both of white thread and also of gold and silver. This is a loose fabric made of three "cordonnets," the centre one being the coarsest, held together with finer threads running in and out across them, and with "brides" to connect and keep the pattern in shape.

Black and white Blonde has during this century been also much made in Catalonia for that graceful national head-dress, the mantilla, but it is not at all equal in quality to similar Lace made in the north of France, of which more will be said further on. In fact Spaniards, though they have always been very good customers for the Lace of other countries, do not appear at any time to have been great Lace producers. 


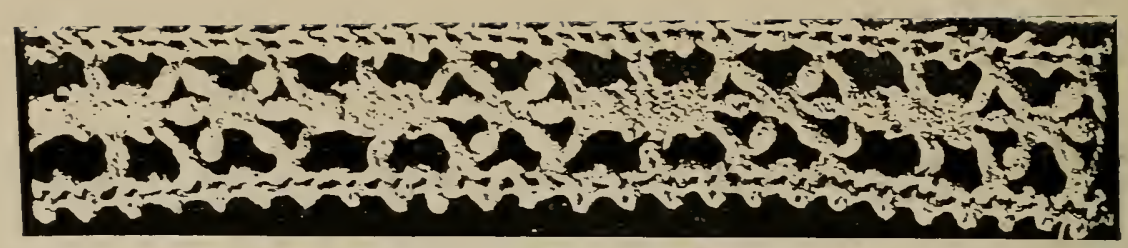

Genoese Plaited Lace.

\section{CHAPTER IV. \\ OF ITALIAN PILLOW LACE.}

BEFORE entering into details concerning Lace that will fall under the above description, some mention must be made of a decorative work of very ancient origin, namely :

PUNTO A GROPPO, OR KNOTTED LACE.

(Now known as MIacramé.)

This must be considered as a very early form of Pillow lace, being made with interlaced threads on a pillow, though by knotting and not by plaiting as in the modern Pillow lace. It no doubt grew out of the knotted fringes that we see represented in Byzantine mosaics, or it may claim a still earlier origin in the same fringes as represented in ancient Assyrian sculpture. During the sixteenth century much of this work was produced in Genoa, but the effect was necessarily stiff and heavy and was not found suitable for other than church and household purposes. 


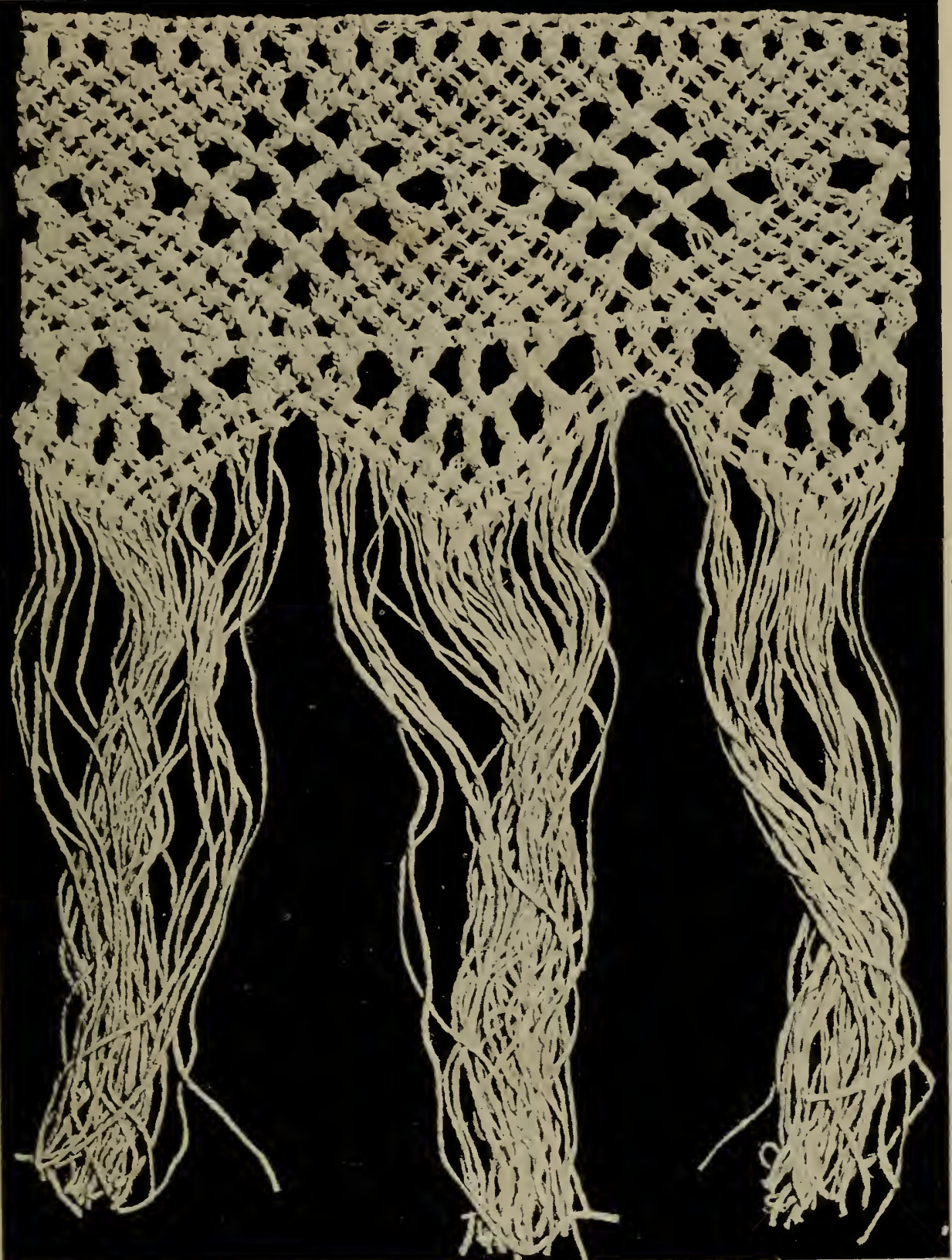

Macramé, or Punto a Gropfo. 

The specimen shown in Illustration XIII. was bought in Italy some fifty years ago, but the work since then has been introduced into this country, and so many books of patterns and directions have been published that any detailed description of it seems unnecessary here. The name "Macramé," by which it has been known to us, is as modern as its revival; it comes from an Arabic word signifying an ornamental trimming.

It is interesting to notice that as we have seen that the looped stitch of netting was the first startingpoint of the needlework button-hole stitch, with which all Point laces are made, so we may consider these knotted fringes as the beginning from which all the future Pillow lace work was developed.

Great rivalry exists between Italy and Belgium as to which of the two may claim the merit of the invention of Pillow lace. While Belgium, as we have seen, can refer to the picture by Quintin Matsys of the girl with the Lace pillow as a proof that the Art existed in the north as early as the end of the fifteenth century, Italy can show on her part the pattern-book for Pillow lace-making preserved in the Museum of the Arsenal at Venice, entitled, Le Pompe, and dated I557, and if this later date should be quoted as antagonistic to her conten- 
tion, it may be fairly allowed that an Art must have been already some time in existence before it could have created a literature.

M. Seguin, favouring the Italian view, is of opinion that the Art spread from Italy through France to Belgium by means of travelling pedlars who, journeying slowly across Europe and stopping everywhere on their road to sell their wares, carried the knowledge of Lace-making into the Flemish provinces, where the population was already familiar with, and skilful in, the manufacture of linen. However that may be, it is certain that Pillow laces of the Italian sort, known to us as

\section{PILLOI GUIPURE,}

seem to have been among the earliest made both in Flanders and in Italy, and that in style of design. they have a distinctly Italian character. It is this Lace about which the authorities at South Kensington decide to be doubtful. One must conclude that they have good authority for believing that what would certainly from its appearance pass for Italian Lace has actually often been made in Flanders. They have therefore labelled the cases containing it as "Flemish or Italian." If a distinctive difference may be suggested between Lace of the same style of pattern made in the two countries, it would appear perhaps 


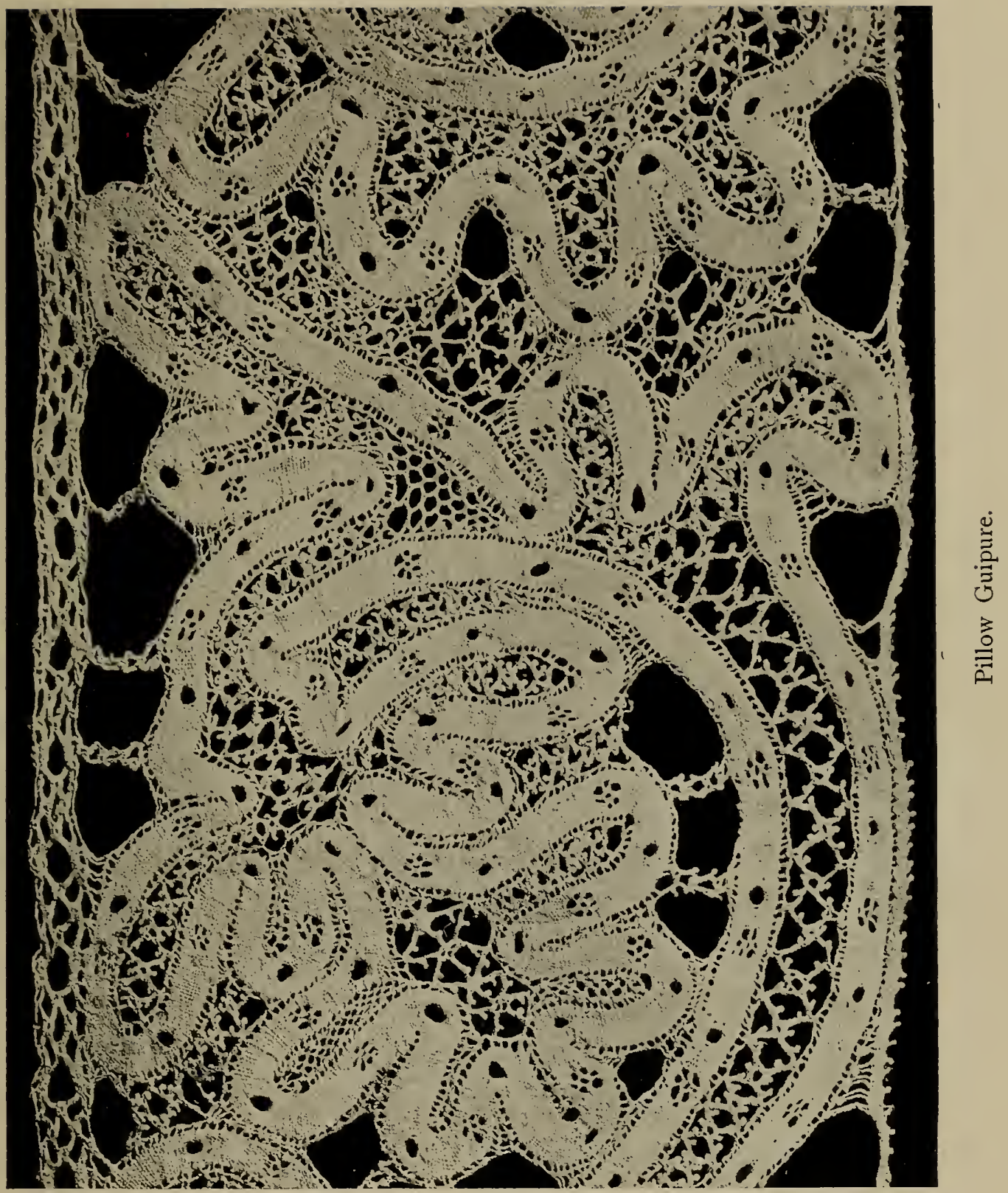



to be in the quality of the thread. As has been said, the inhabitants of the Flemish provinces have always been noted for their superior skill in spinning and weaving linen, and whether from lack of such skill or from a difference in national taste, there is no doubt that Italian Lace generally of all kinds is heavier and stouter in character than that produced in the north of Europe. Illustrations XIV. and XXIX. should be compared.

Pillow Guipure may be described as composed of a tape, made on the pillow so as to follow the curves of the pattern and connected by "brides" also made on the pillow, that is, made of twisted or plaited threads, not as in Needle lace covered with buttonhole stitches. The "brides" are sometimes ornamented with "picots," and the open spaces are filled in with "à jours," also pillow-worked.

This Lace, though flat, is, from its excellent designs of a bold Renaissance character and its good workmanship, often very handsome in appearance.

A variety on this is the mixed Needle and Pillow lace, called

\section{MEZZO PUNTO.}

(Fr. Point de Canaille.)

In this the "à jours" and "brides picotées" are worked in needle stitches and complete in Point the 
pattern traced out with Pillow-made tape. Sometimes this mixed Guipure is grounded with a coarse needle-made "réseau" instead of "brides," but whether so or with "brides," it is too often made not with tape worked to the pattern on the pillow, as is the wholly Pillow Guipure, but with a woven tape made first separately and then tacked on to the pattern as outlined on parchment; the result is that clumsy puckers and folds spoil the turns and curves of the design, a defect, as we all know, which has been faithfully copied in the modern revival of the Lace. Whether owing to this or to the mixture of methods, or to faults of design, the Mezzo Punto never has the simple, free effect of the Pillow Guipure, and is very far from attaining to the richness of Needle Point.

It has been said, though with what amount of truth we do not know, that this Lace originated in Naples, and was meant to supply the poorer folk with a cheap imitation of the rich Point laces worn by the Court. There seems no doubt that both mixed Lace and Pillow Guipure were intended to copy the Venetian Points, and from being easier to work, and less costly to purchase, they gained favour very rapidly. 


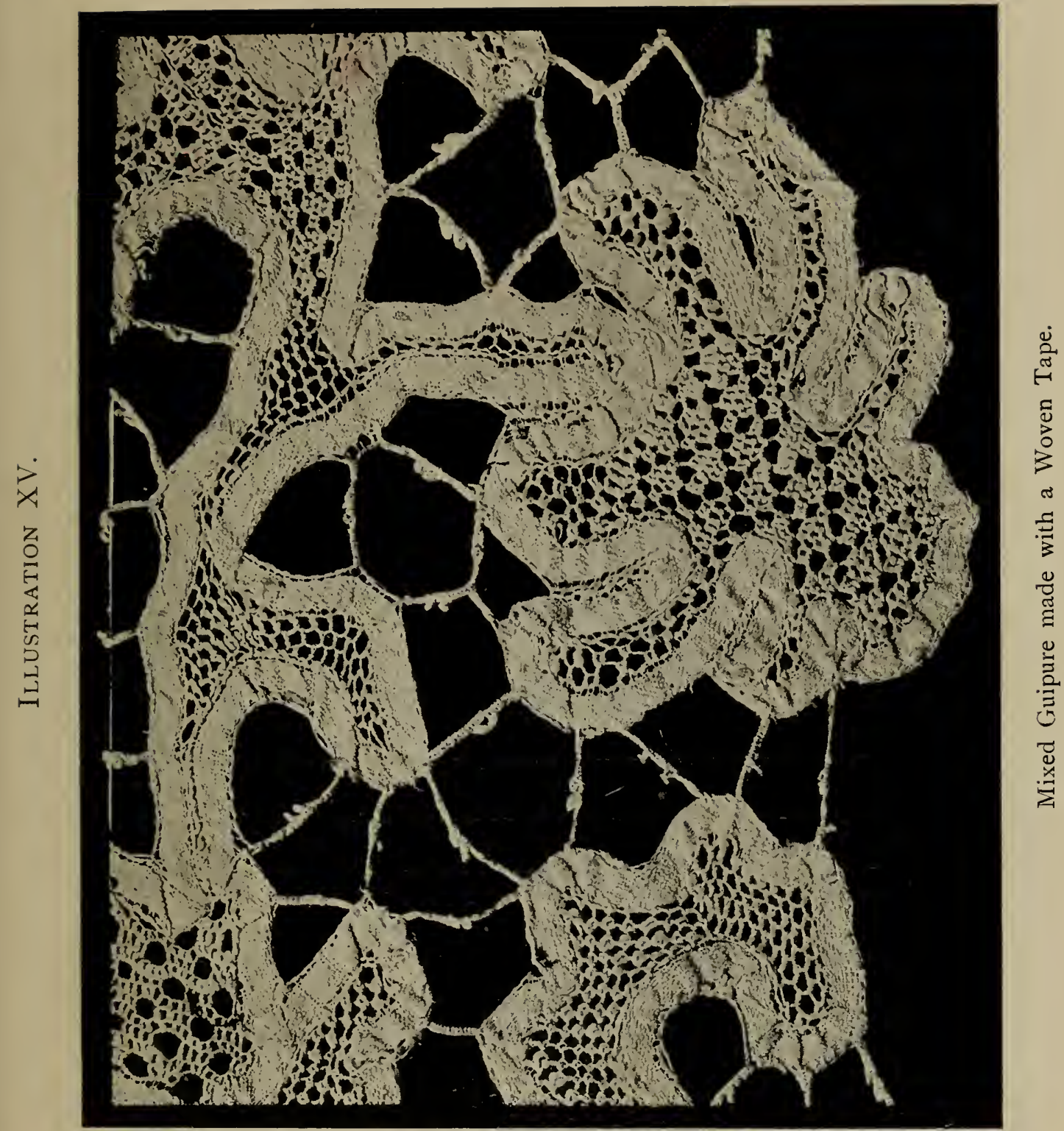



GENOESE LACE.

(It. Punto di Genoa.)

As Venice was the great centre for Needle-point, so was Genoa for Pillow lace-making in Italy, and during the greater part of the seventeenth century a constant supply was produced in that town and its neighbourhood of the handsome vandyked and scolloped border Lace, called from the use to which it was put, Collar lace. In the pictures of Rubens and Vandyke we see it frequently represented as trimming the broad falling linen collars both of men and of elderly ladies. It can be distinguished from Flemish Lace, also employed in the same way, by its greater boldness of design.

The younger ladies also made great use of it as trimming for the shoulders of their décolleté dresses, and also for sleeves, aprons, etc.

COLLAR LACE.

Collar Lace is of two kinds, both of which are represented in Illustration XVI. That of which No. 2 is a specimen resembles in principle the Pillow Guipure already described. A scroll-like pattern, as of tape, is turned and twisted into forms of con- 
siderable elegance which at the same time compose the deep scollop of the required shape. This Lace is round and not pointed in its outline. The whole is strengthened and connected by short "brides."

\section{PLAITED LACE.}

(Fr. Point de Gènes frisé. It. Merletto a piombini.)

No. I is generally pointed or vandyked in shape, and is worked in a somewhat unusual manner; the Lace is made entirely with plaits of four threads each, following the design, and with little oval enlargements resembling ears of wheat, which are sometimes arranged as beads on a thread and sometimes composed into trefoils or quatrefoils, or spokes radiating from a common centre.

\section{GENOESE TAPE GUIPURE.}

Besides the border Lace chiefly used for trimming collars which has been already described, a Lace sometimes known as Tape Guipure is also attributed to Genoa. A specimen is shown in Illustration XVII. which will sufficiently explain the name. A convoluted tape, but made to its shape on the pillow with no unseemly puckers or folds, seems to wind for ever through the design. Great ingenuity is 


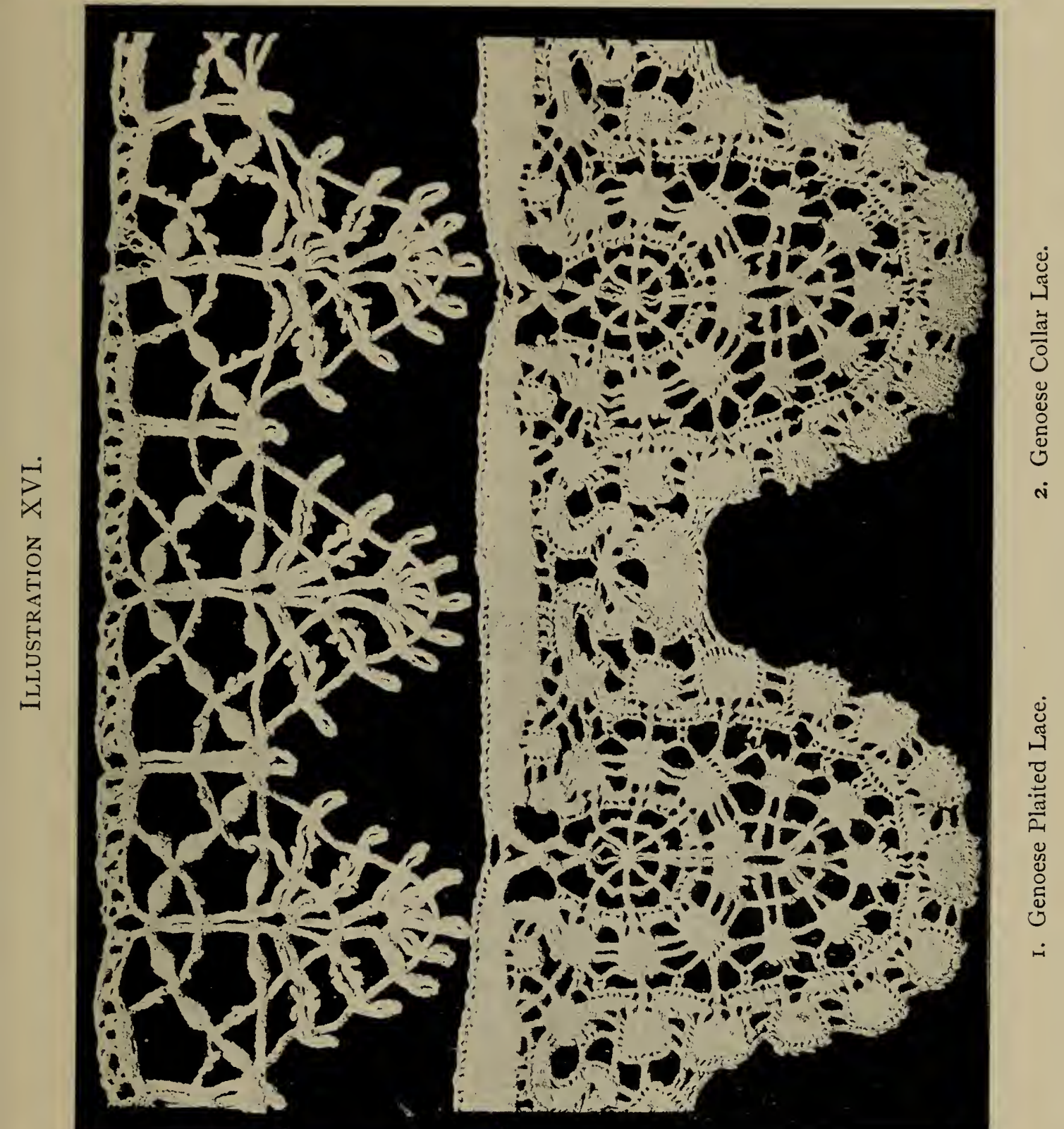



ILLUSTRATION XVII.

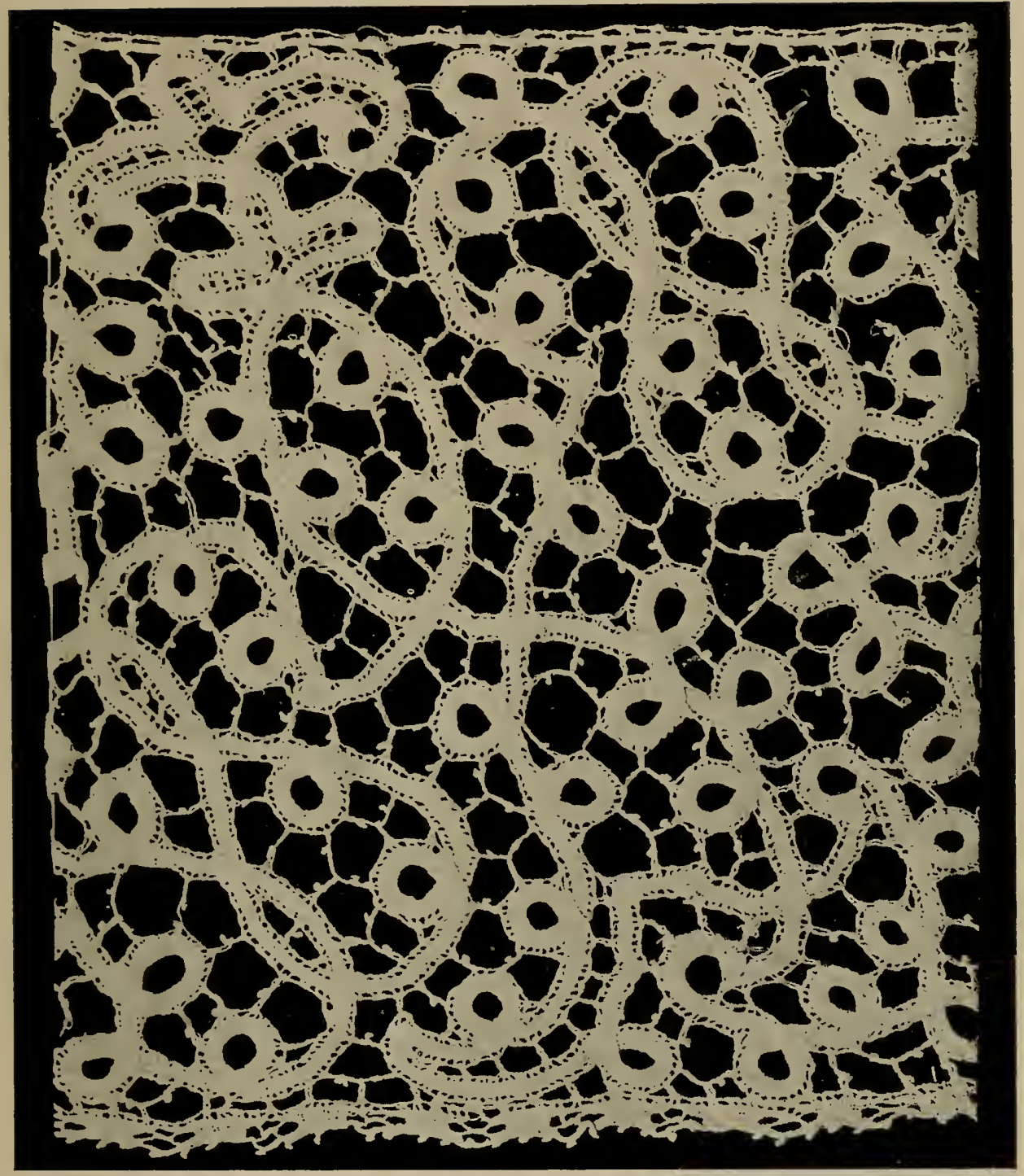

Genoese Tape Guipure. 

shown in the even and well-balanced distribution of the pattern, if pattern it can be called, where so little order or intention can be traced. With the enrichment of numerous "picots," and also sometimes of ornamental "à jours" filling in the looped spaces, this Lace has often a very good though perhaps monotonous effect. It has been much used for church vestments, and was frequently of considerable width.

\section{PUNTO DI MILANO.}

(Eng. Milanese Pillow lace.)

It is needless to say that neither this Lace nor "Punto di Genoa" are rightly called "Punti" or Needle-point lace; they are both made on the pillow. The name "Punto di Milano" is, however, so commonly known in connection with it, that it would be pedantic not to recognise it, though with a protest. It was like the preceding Laces, of Genoese origin, but has survived till recent times in Cantù, near Milan. It is by far the most beautiful, as well as the best known of Italian Pillow laces. It much resembles the Genoese Tape Guipure, but with far less of monotony, and much more of graceful design in the style of its patterns. In some fine specimens, such as that represented in Illustration XVIII., coats 
of arms are often introduced, probably when the piece of Lace was made by order of some prelate or personage of noble family; but as a rule easy-flowing scroll-work fills up the composition. This is the only Italian Pillow lace which is grounded with "réseau," a fact that marks it as relatively late in point of date.

It is somewhat singular that this "réseau" should very much resemble that of Valenciennes, having a diamond-shaped mesh formed with a plait of four threads (See Fig. 7, Illustration II.), though the two kinds of Lace are in other respects of totally different construction. In "Punto di Milano," as will be easily seen by referring to the illustration, the pattern is made first on the pillow by itself, and the "réseau" ground is worked in round it afterwards, sloping in all directions so as to fit into the spaces; while Valenciennes is worked all in one piece on the pillow, pattern and "réseau" together.

The difference here noticed forms a very marked distinction between two kinds of Pillow lace, one of which seems to have originated in the Pillow Guipures that we have been considering, which in the case of "Punto di Milano" were afterwards, so to speak, fitted with a "réseau" ground; the other kind is represented in Italy by the various peasant 


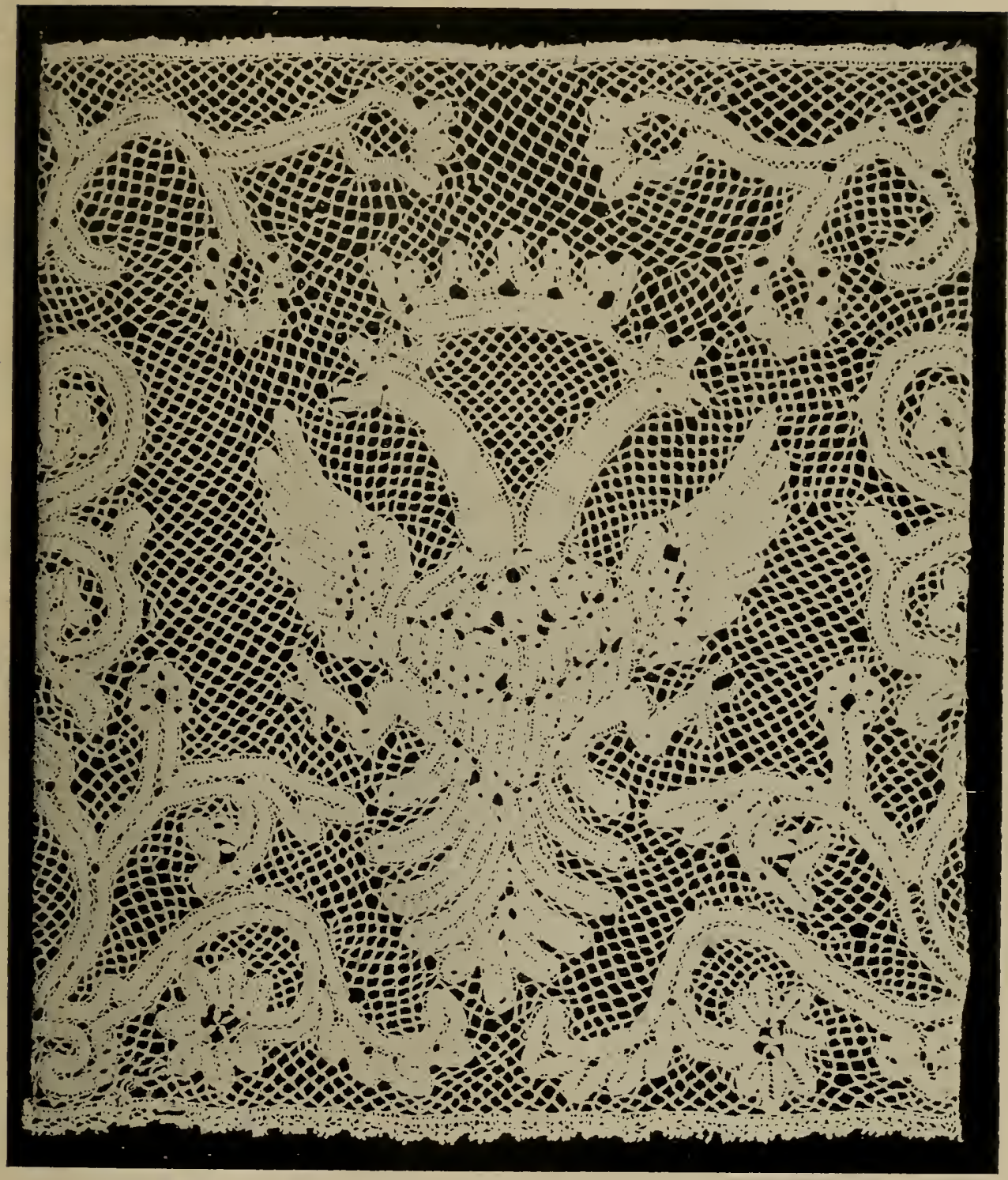

Milanese Pillow Lace. 



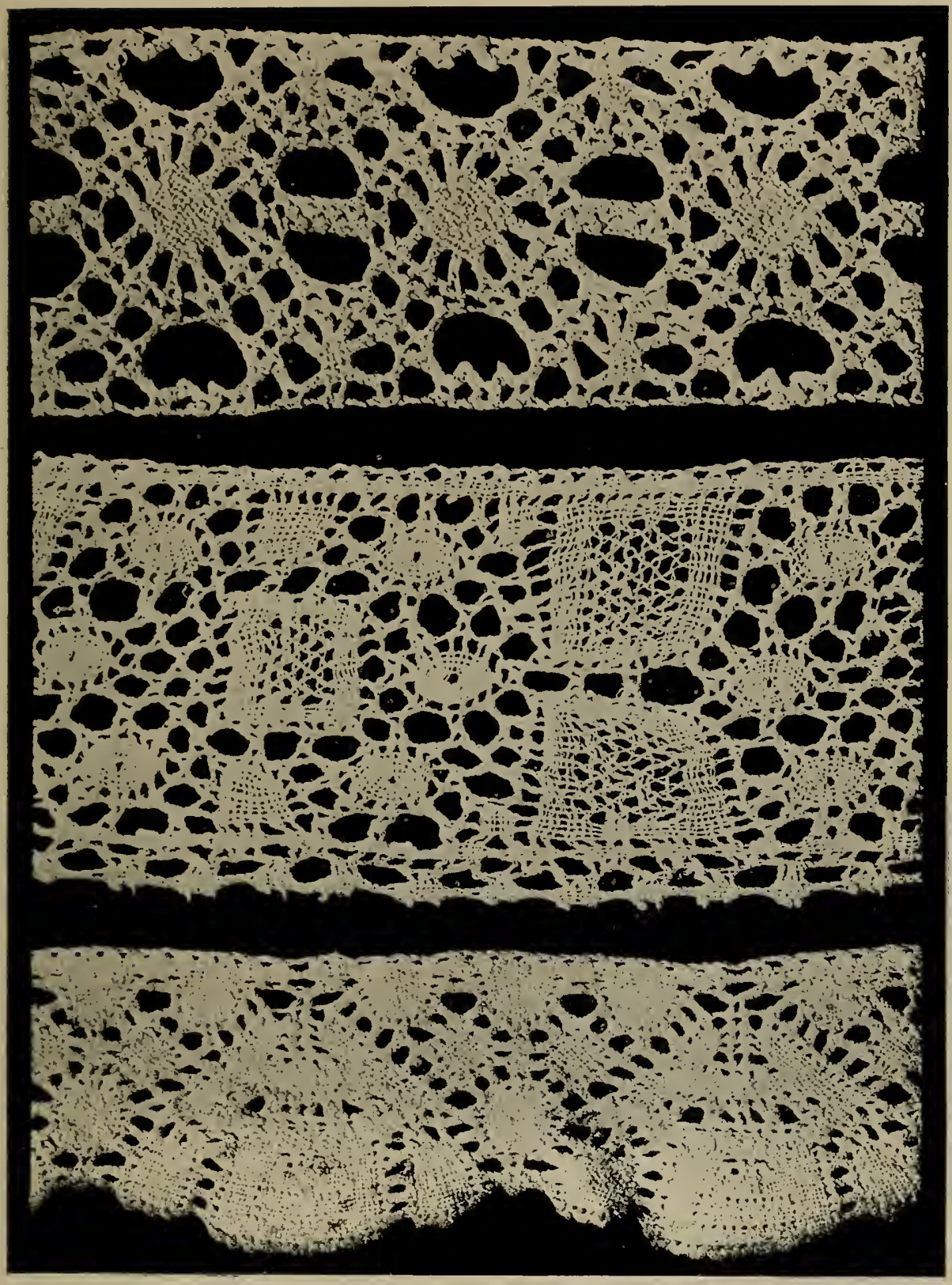

Italian Peasant Lace (three specimens). 
Laces, of which three specimens are given in Illustration XIX. These are worked all in one piece, with one set of threads, forming as it were the woof and warp of the material. This can be almost verified by a close examination of the facsimile print (notice No. 2), though of course more certainly with the actual Lace. No. I is worked in the same manner as the plaited Genoese Collar lace, that is, with plaited threads in sets of four. The designs of these peasant Laces are often very good, though the thread with which they are made is coarse, and their general effect thick. They were chiefly used for household purposes.

Some thirty or forty years ago, before the time when railroads had become universal in Italy, and when the traveller was fain to rumble along during a three or four days' journey in vetturino between Rome and Florence or Naples, the rough country inns at which he stopped for the night no doubt left much to be desired in the way of good food, cleanliness, and comfort; but if he could take it as a consolation, the silk hangings of his bed, his sheets and pillow-case, his towels and tablecloth, were nearly sure to be adorned with this strong and probably home-made country Lace. He soon found, moreover, that after the indispensable bargaining enjoyed 
by both parties alike, he could, for a very reasonable consideration, make the Lace his own. So the dirt and discomfort are forgotten, and the recollection of the amusing incident, together with the Lace, remains. It is now no longer made, nor is any more of it to be bought.

\section{MALTESE LACE.}

A notice of this Lace is added to this chapter be. cause of its very strong resemblance to, and probable development from, the Genoese manufacture. Mrs Bury Palliser, in her History of Lace, gives a sketch of a representation of Lace copied from a Cardinal's monument in the church of St. John in Valetta, from which it would seem that the wavy character of the designs of recent Maltese Lace may possibly be of ancient origin. But there seems no doubt that a great improvement took place both in its designs and execution in consequence of the efforts of Lady Hamilton Chichester, who, in 1833 , brought lace-workers over from Genoa to teach their craft in the island. The Lace is made in white thread and in black and white silk; in the white silk specimen shown in Illustration XX. the little wheatear ornament so characteristic of Genoa is clearly seen. 


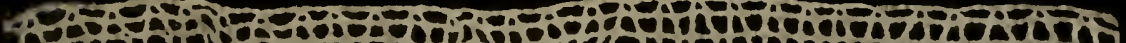

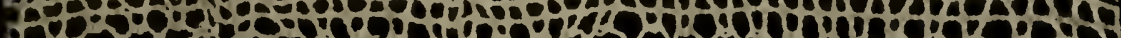

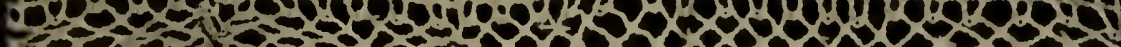

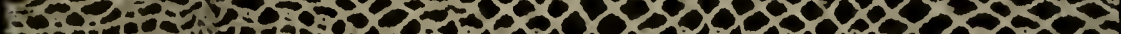

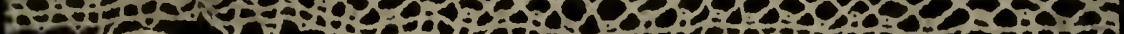

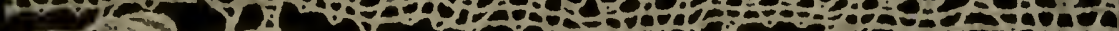

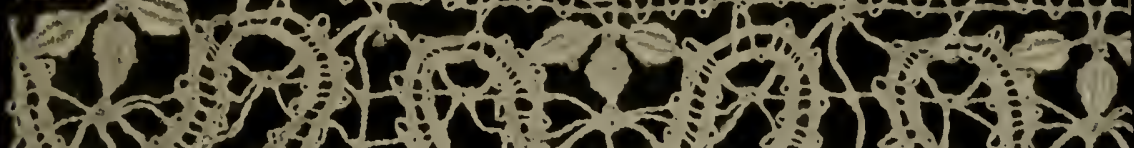
5 (1)

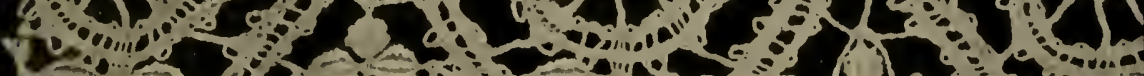
(1)

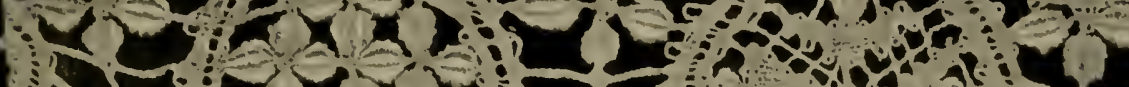

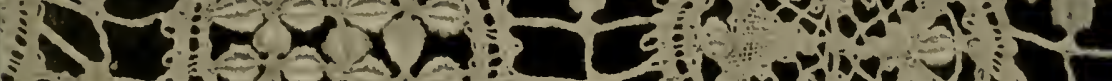
(ji,

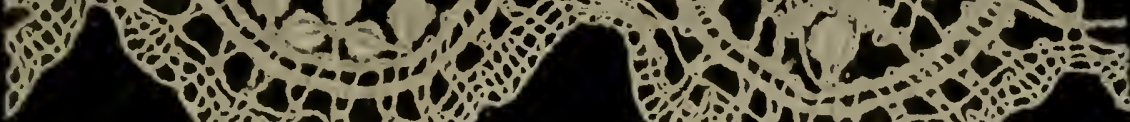
cisionision bitis Q ki's=-

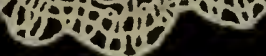

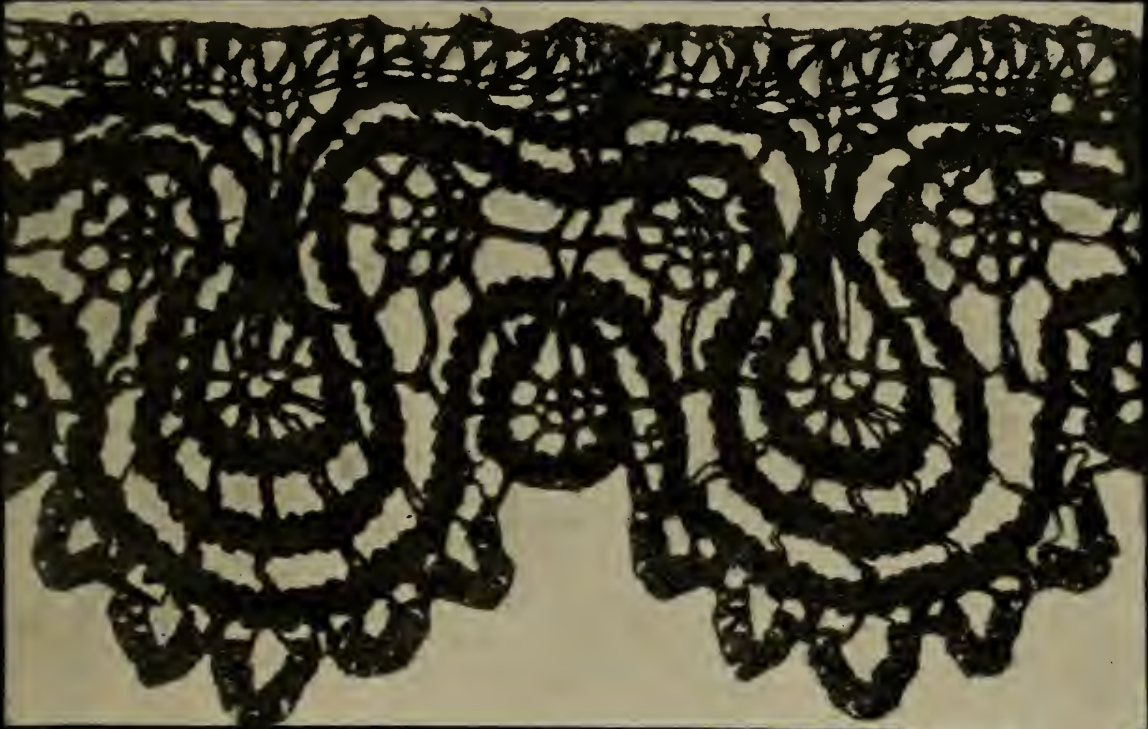

Maltese Lace (Black and White Silk). 



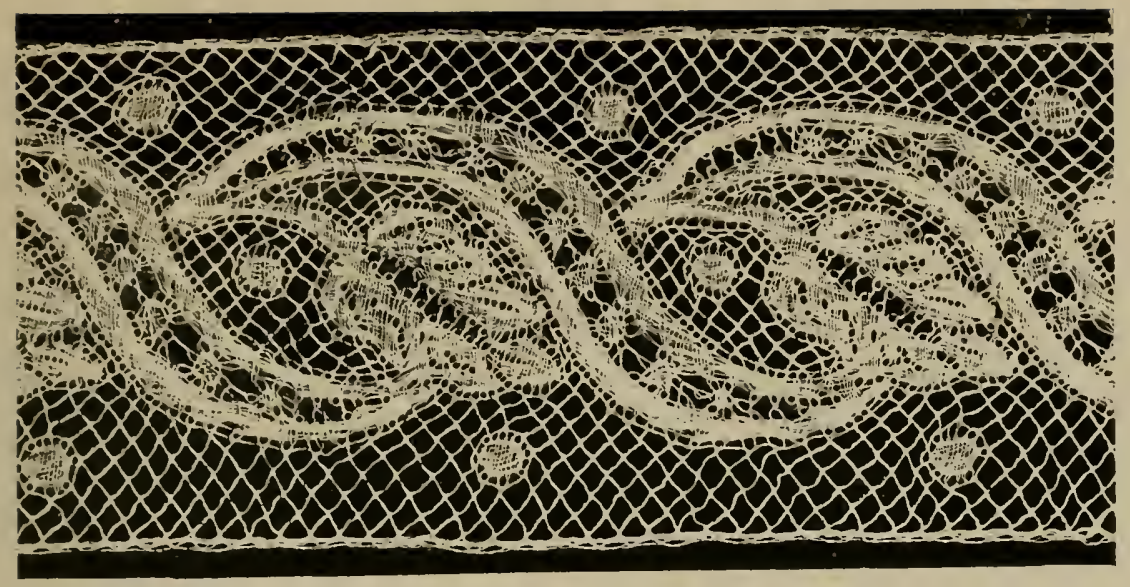

Modern Valenciennes.

\section{CHAPTER V.}

\section{OF FRENCH LACES.}

\section{POINT D'ALENÇON.}

I $\mathrm{T}$ is said that Needle-point lace was made at Alençon as early as 1650 or thereabouts, but though mention has been found of it by name at that time, it did not attain to any great perfection or celebrity till the manufacture was taken up and encouraged by Colbert, the well-known minister under Louis the Fourteenth. True to the principles that have governed French policy in commercial matters to this day, great jealousy and annoyance had long been felt by the various ministers of the crown at the large sums of 
money yearly spent upon the importation of Venetian and other Italian Laces, then thought an indispensable part of the dress of the Court. Repeated sumptuary laws were passed to check the trade, but fashion is stronger than laws, and as, judging by their portraits, the royal family themselves were among the chief culprits, these naturally had but little effect. To one issued in 1660 we owe an amusing satire callel "La Révolte des Passemens," passement (Gimp or Guipure) being the old French word including Lace and embroideries. The various Laces enumerated, "Poincts de Gènes, de Raguse, de Venise, d'Angleterre et de Flandres," down to the humble "Gueuse," the equivalent of the modern Torchon, are supposed to assemble and to make indignant lamentation over their exclusion from Court. The poem is dedicated to Mademoiselle de la Trousse, and it is supposed to have been written by someone belonging to the circle of Madame de Sevigné. The wit is perhaps a little laboured. The gist of it is as follows :-

One of the Laces addressing the rest with some warmth, says :

"Dites moi je vous en prie

Poincts, dentelles ou broderies

Qu'aurons nous donc fait à la court

Pour qu'on nous chasse haut et court," etc. 


\section{ILLUSTRATION XXI.}

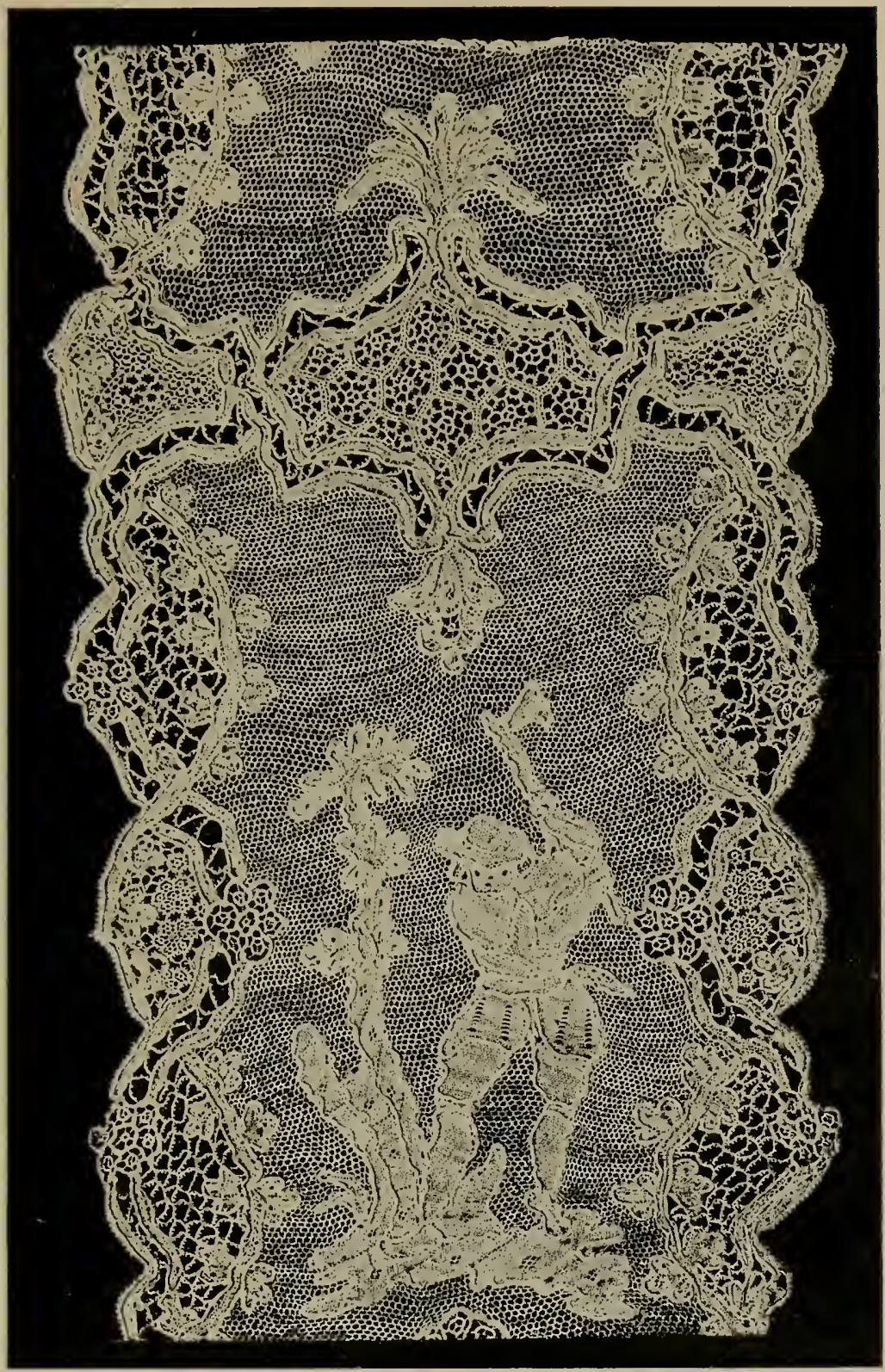

A Lappet, Point d'Alençon. 

To which "une Grande Dentelle d'Angleterre" replies :--

"Cet infortune sans seconde

Me fait bien renoncer au monde.

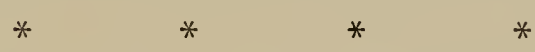

Pour ne plus tourner à tout vent

Comme d'entrer dans un Couvent."

But the Laces of Flanders will not patiently submit to be so extinguished, and many angry verses ensue. At last a "Dentelle noire" in despair hires itself out to a game merchant for nets to catch snipe and the rest :-

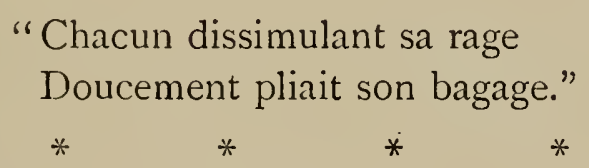

when "une pauvre malheureuse la Gueuse" (it was the Lace of the common people) declares that she at least will not give in, and that if they will follow her lead she will certainly replace them in their former position.

"La dessus le Poinct d'Alençon

Ayant bien appris la leçon

Fit une fort belle harangue,"

and the result was that they all repaired to the Fair of St. Germains prepared to do battle for their rights. However, the King brought down his big guns and 
the brave Laces forthwith took to their heels. They were condemned at a court-martial, some to be made into tinder for the sole use of the King's mousquetaires, and others to be sent to the galleys or burned alive; but Cupid, "le petit dieu plein de finesse," makes intercession and they are forgiven and received again into royal favour.

The poem is also interesting as giving us the names of the Laces most in repute at the time. "Point de Raguse" is not easy to identify. Ragusa is a town on the Dalmatian coast, and being near to the Venetian dominions, though not at the time included in them, the Lace was probably of much the same kind as that produced in Venice itself; if so, its fame is at present extinguished by that of its more powerful neighbour.

The edict against Lace must have made a great impression on society, for Abraham Bosse, whose contemporary engravings are a mine of information concerning the dress and manners of the day, gives us an amusing record of the crisis. He depicts the despair of the lady of fashion now attired Puritan-wise in plain hemmed linen cuffs, collar and cap, as she mournfully packs away all her rich lacetrimmed costumes, and bewails her sad fate in heartbroken verses. 
The failure of past edicts was, however, the immediate cause of a great success. In order to exclucle foreign manufactures Colbert hit upon the better plan of encouraging those of his own country. He induced Venetian lace-workers to settle near his daughter-in-law's castle of Lonray at Alençon, and selected a competent directrice in one Catherine de Marcq, and finally in 1665 a flourishing Lace factory was established, and Lace was produced in exact imitation of Venetian Point, which rivalled if it did not surpass the Italian original.

It was called by Royal Decree "Point de France." The name lasted in connection with Alençon Lace till about I790. It is impossible now to distinguish the earliest Lace so called and produced in Alençon from the finest Venetian Point. The designs are in the same style, and the workmanship is extremely beautiful; but by degrees, as greater freedom was very wisely allowed to the workers, a new and separate style developed itself. The patterns became smaller and more delicate, finer thread was employed than that made use of in Italy, "brides" became closer and more regular in arrangement, and finally the needlework "réseau" ground was invented in imitation of the Pillow laces of the neighbouring Flemish Provinces, and we see attained in per- 
fection the style of Lace now known as Point d'Alençon.

The Needle-point "réseau" was worked at Alençon about the year $\mathrm{I} / \bar{\gamma}$, but combined with it the patterns still retained a strong Renaissance character. Running scroll-like bands filled in with fanciful "à jours" are a special characteristic of this period; they wave from side to side of the piece of Lace, form part of the edge and enclose spaces which are decorated with flower forms conventionally treated. (See Fig. 2, Illustration XXII.)

A variety of this style is to be met with which has sometimes been distinguished as a separate Lace under the name of "Argentella." Its peculiarity is a large and very ornamental honeycomb filling, made use of alternately with the ordinary "réseau" as a groundwork for the design, with a very beautiful effect. Mrs. Bury Palliser mentions that some of it was sent to her from Genoa, but most authorities seem agreed that it is undoubtedly Point d'Alençon.

Towards the beginning of Louis the Sixteenth's reign Alençon patterns were much modified, the flower representations became more and more naturalistic (see the beautiful representation of roses in Fig. I of the illustration), and the groundwork was sprinkled with spots or leaves. Finally under the Empire 


\section{ILLUSTRATION XXII.}

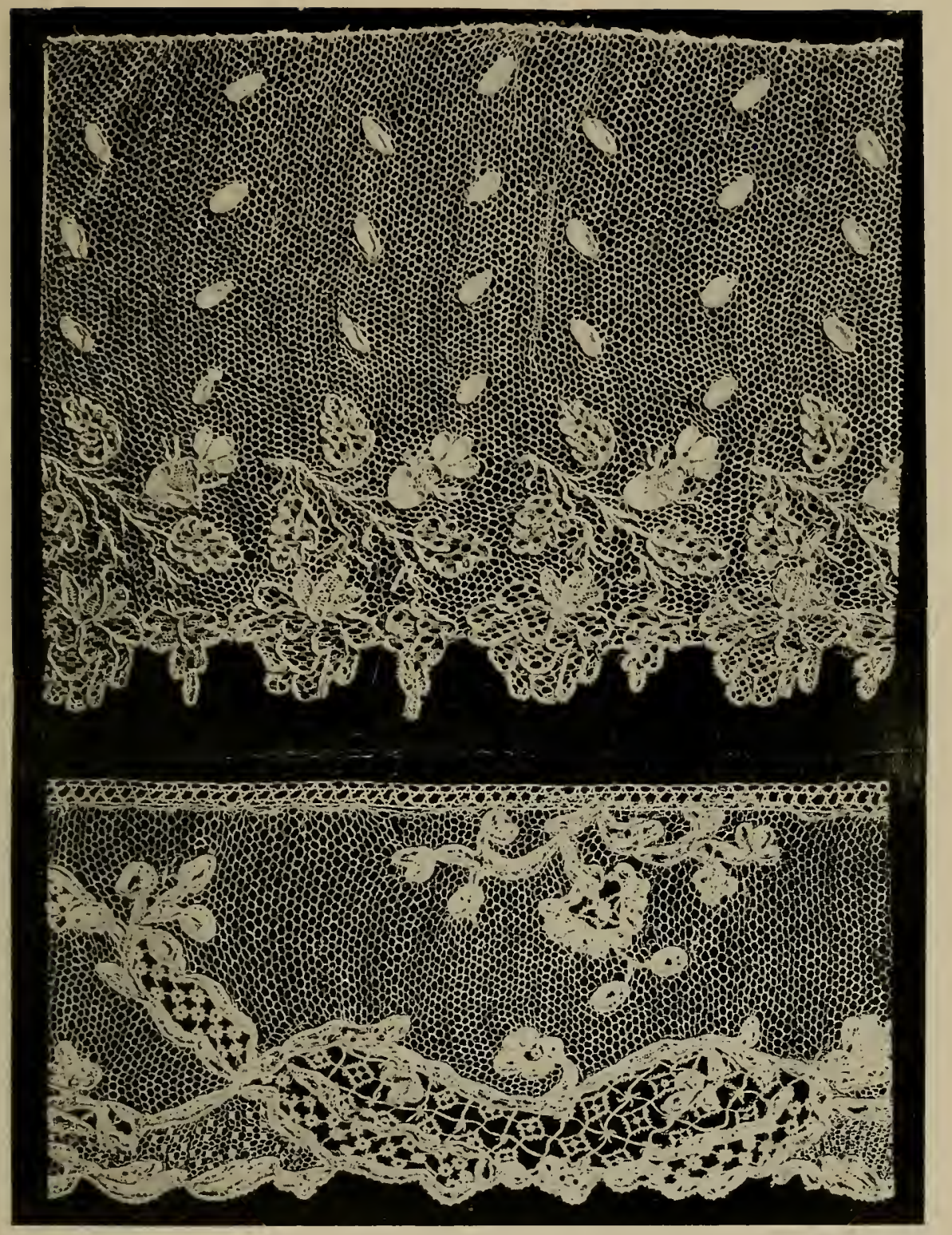

I. Early Point d'Alençon.

2. Later Puint d'Alençon. 

the last stage was reached, the pattern dwindled and became little more than an outline of "cordonnet," and the "réseau" "semé de larmes" betokened the extinction of this beautiful Art.

The peculiarity by which Point d'Alençon can always be recognised is its "cordonnet," which is firmer and clearer than that of any other Lace, owing, it is said, to the fact that it is worked over horsehair ; it is also firmly and closely covered with button-hole stitching throughout. The Alençon "réseau" is shown in Fig. 3, Illustration I. It is made with a double-twisted thread throughout, the looped stitches being twisted on to horizontal threads previously fixed across the width of the Lace, giving an effect of lines or rows to the network.

Point d'Alençon is Lace of a very fine order, both from the beauty of the designs during the time of its prime, and also from the wonderful delicacy of its workmanship, which last can scarcely be appreciated except with the help of a magnifying glass. The specimen shown in Illustration XXI. is part of a lappet, the length of which is divided into sections by a very beautiful framework filled in with delicate "à jours"; each section contains a little group representing one of La Fontaine's fables; a truly marvellous triumph of needlework. 
POINT D'ARGENTAN.

Argentan is a town in the immediate neighbourhood of Alençon, and the Lace was made there under the same direction. Its marked peculiarity is that the "réseau" ground is not made of single threads only, but that the sides of each mesh are worked over with button-hole stitch. (See Fig. 4, Illustration I.) The work is so fine that it can scarcely be detected with the naked eye, but the effect can easily be recognised as the hexagonal mesh is larger, and has a stiffer appearance, than is the case with any other Needle-made lace.

\section{VALENCIENNES PILLOW LACE.}

This most beautiful of French Pillow laces is now no longer made in France itself, its manufacture having been transferred to Ypres, in Belgium.

It belongs to that class of Pillow lace which is made in one piece on the pillow, the same threads forming both "toilé" and "réseau" alike.

The peculiarity of all Valenciennes Lace is the absence of any "cordonnet"; also the closeness and evenness of the texture of the "toile" which resembles the finest cambric; but notwithstanding that 


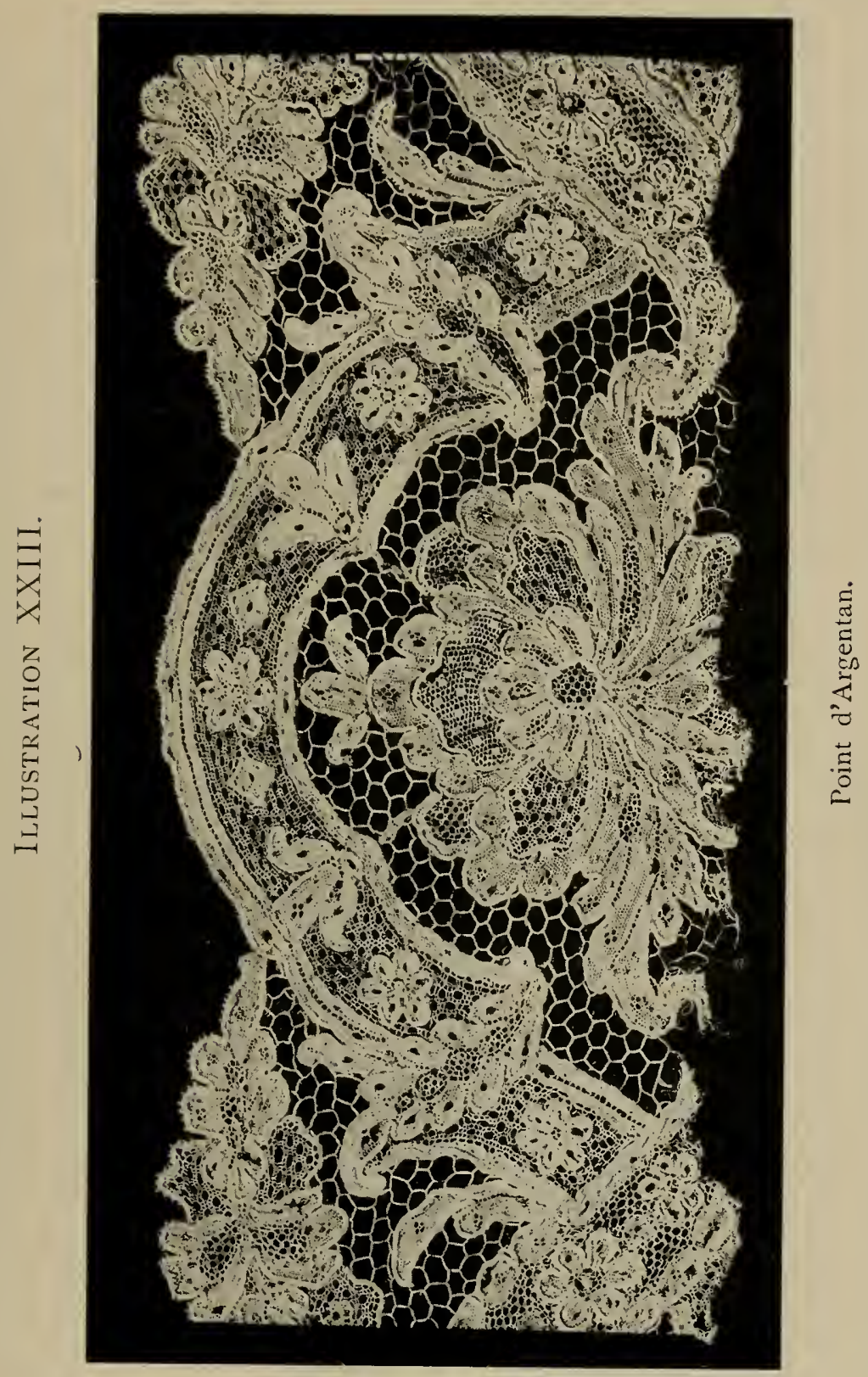



these characteristics may always be recognised, there is a very great difference between the earlier and the later styles of the Lace. In the preceding pages it has been explained that the earliest Pillow lace was not made with the "réseau" ground; on the contrary, this was one of the latest developments of the lace-making Art. Even when "bride" work had been abandoned there occurred a transition state before the simple net-like character of the "réseau" was perfected, and accordingly we find the earliest Valenciennes Lace grounded with, so to speak, a fancy mesh, thicker and closer in effect than the open "réseau" of later date. The difference will be seen between the two specimens shown in Illustration XXIV., and there also will be seen a difference in the style of design strongly corroborative of the above statement; for the specimen given of the thick-grounded Lace is in excellent Renaissance style, whereas the later Lace has degenerated into naturalistic floral representation. It would appear that the early Valenciennes Lace was produced, generally, in the neighbouring district, but that it was in the town itself that the pure "réseau" was invented, and forthwith the town workers, proud of their invention, proceeded to appropriate to their Lace the name of "Vraie Valenciennes," $\mathrm{P}$ 
pretending that this Lace could not be made elsewhere; and they moreover stigmatised the older style still produced in the country villages as "Fausse Valenciennes." The palm of merit would not be now altogether awarded in their sense; notice the beautiful specimen shown in Illustration XXV. Here a Renaissance framework encloses a naturalistically treated carnation flower. The carnation has ever been a favourite with embroiderers and lace-workers, and in this instance is most beautifully represented.

The "réseau" of the "Vraie Valenciennes" is made of four threads plaited throughout (see Fig. 7 , Illustration II.), hence its great durability and the name given to it by its admirers, "Les éternelles Valenciennes."

\section{POINT DE PARIS.}

It is sometimes contended that there is no special Lace properly called by this name, but that it is merely the designation of a particular kind of "réseau," also described as the Fond Chant "réseau." (See Fig. 8, Illustration II.) Still there is no doubt that a manufacture of some sort of simple Lace was carried on extensively during the seventeenth and eighteenth centuries, in the Isle de France and in Paris itself, until annihilated by the 


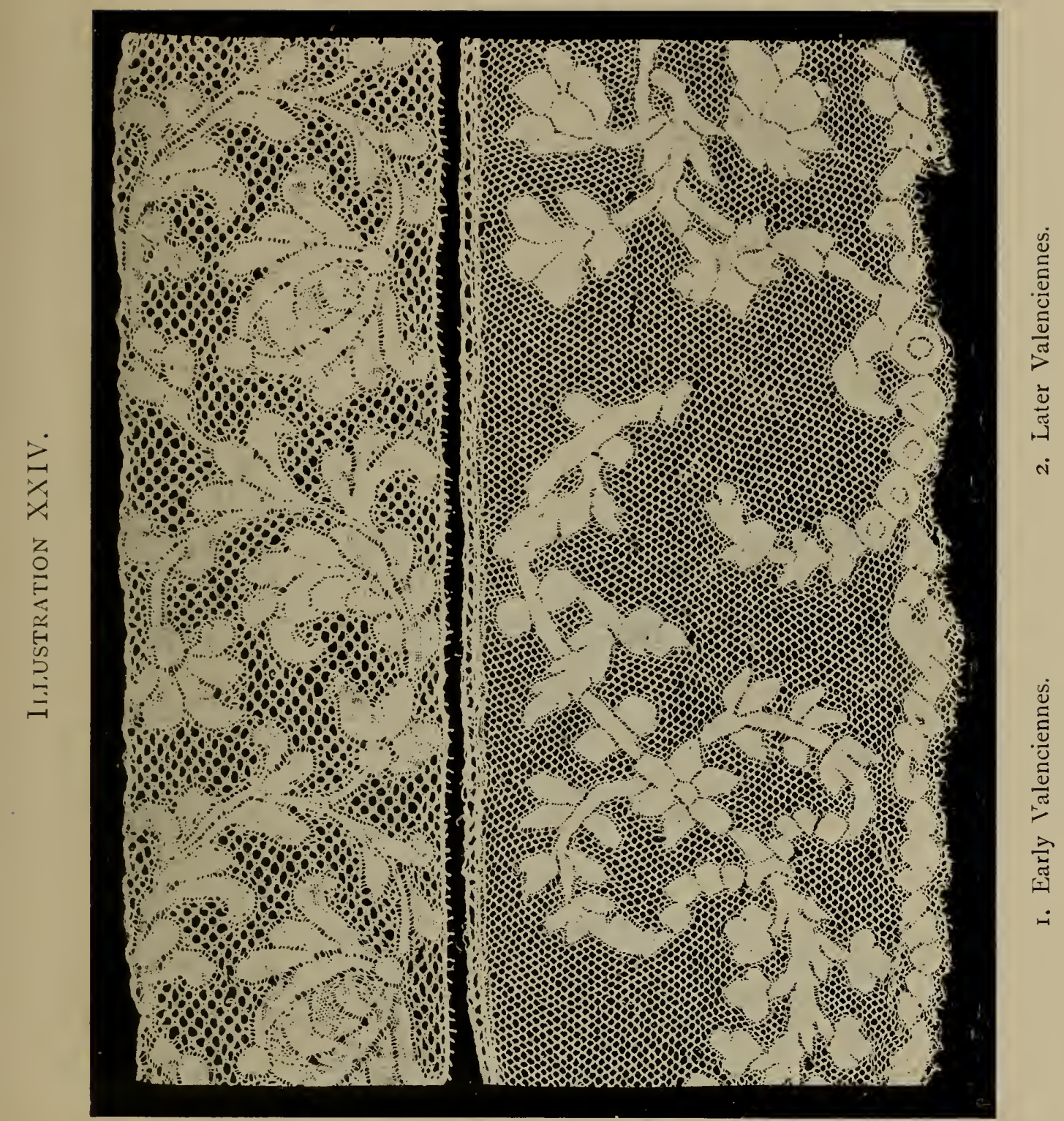





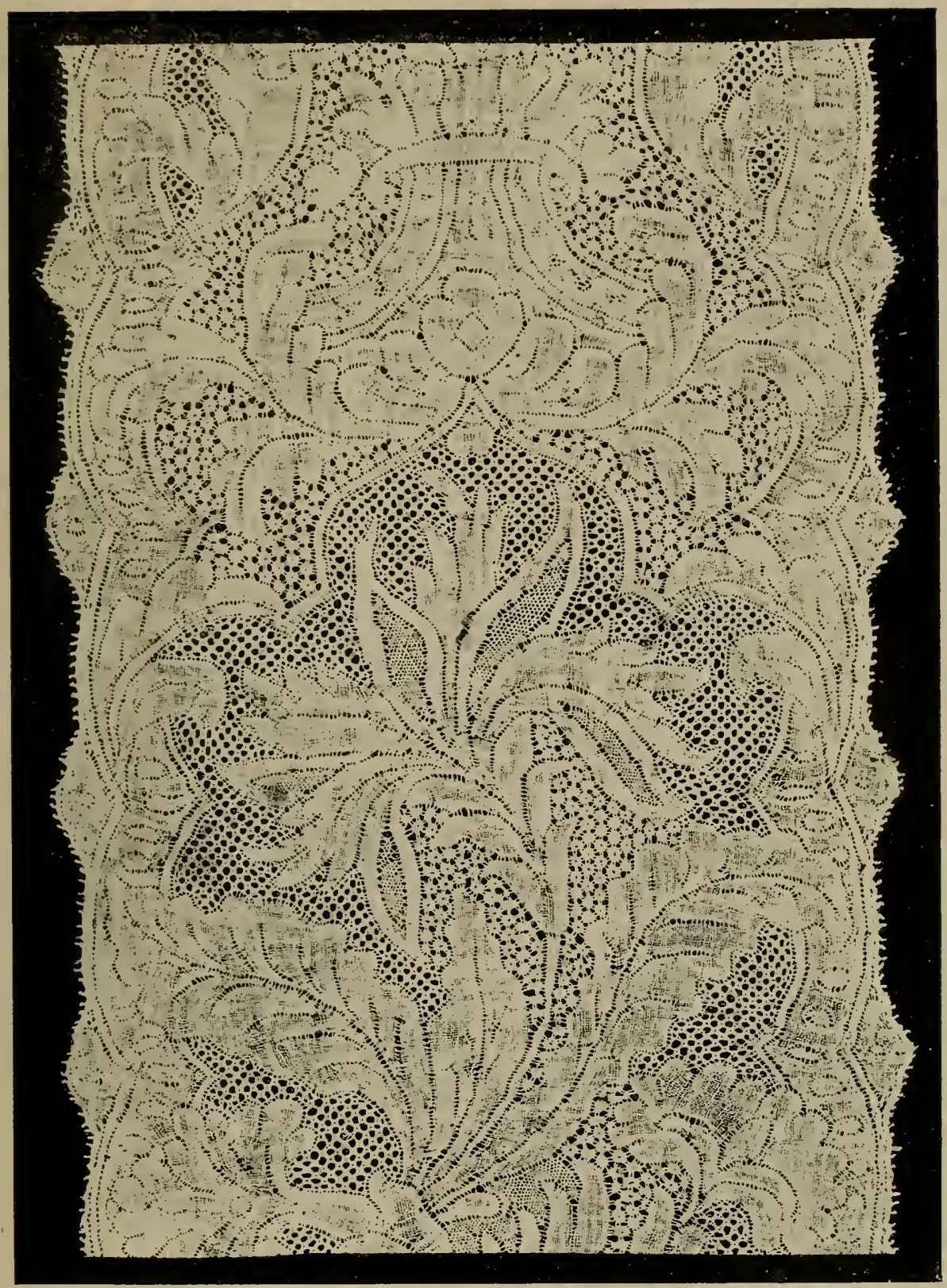

A Lappet, Early Valenciennes. 



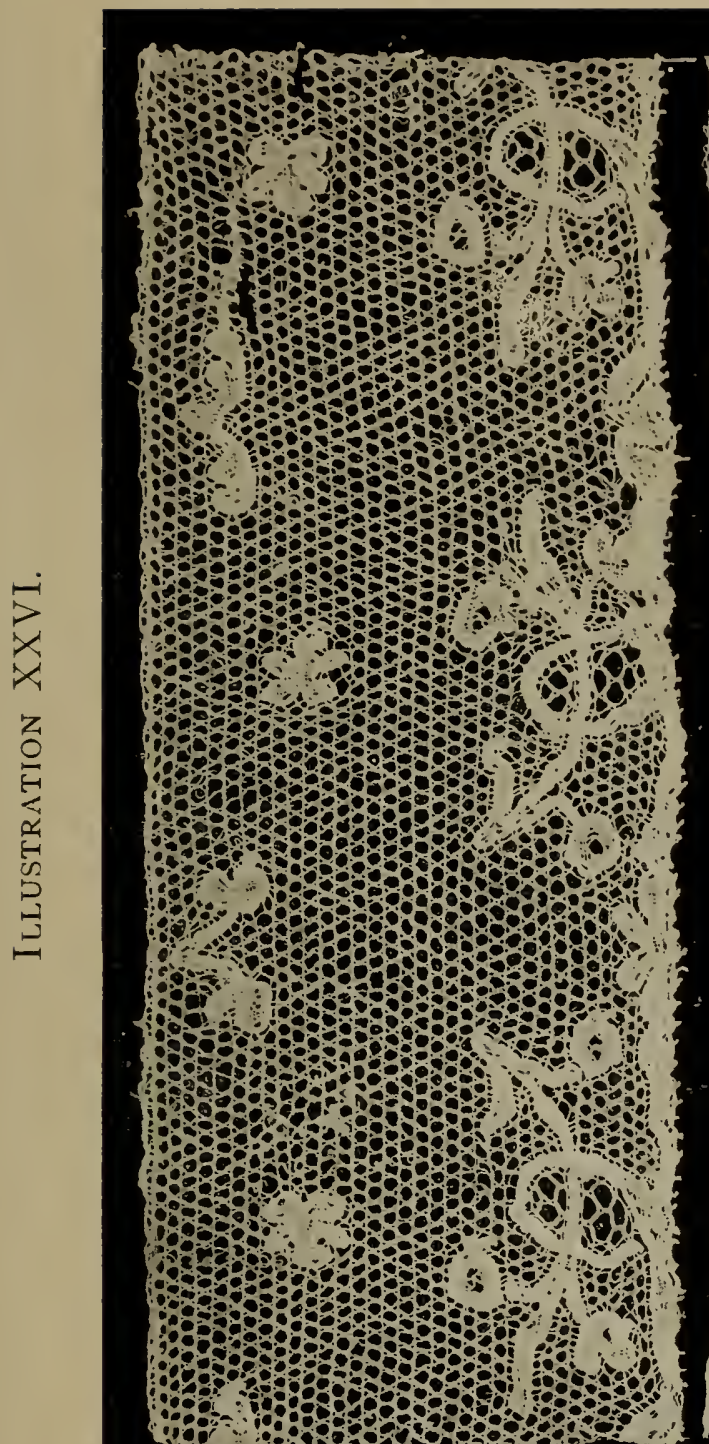

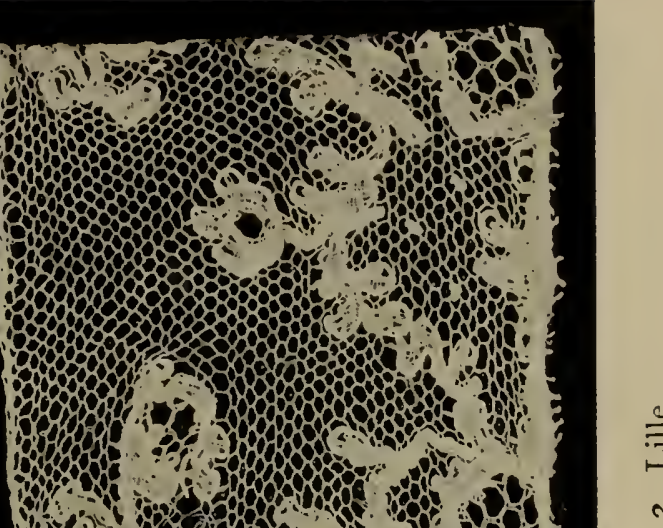
in

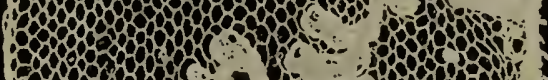

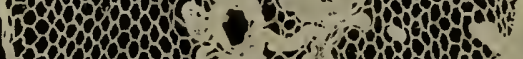

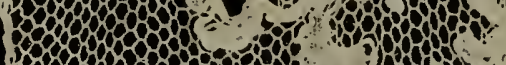

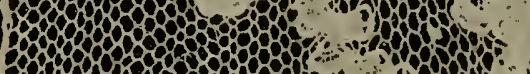

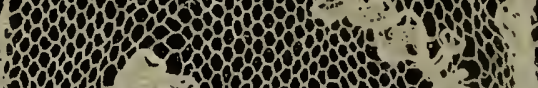

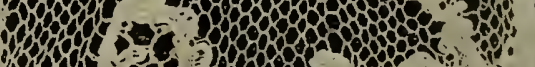

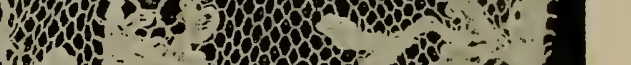

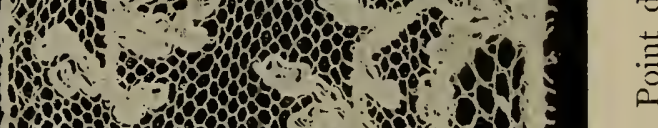
1906000000000 -

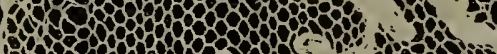
0030303 H of

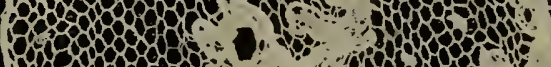

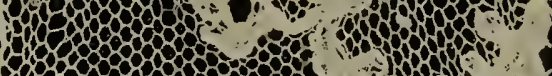

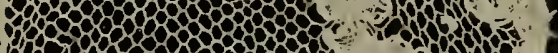

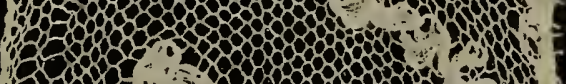

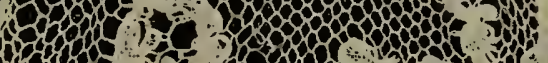

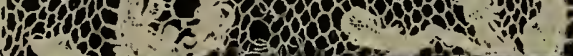

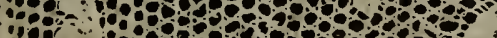

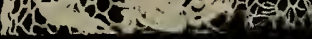



Revolution, and that its characteristic was this same "réseau." As shown in the specimen-Illustration XXVI.-the style of pattern is extremely simple, and consists usually of small leafy sprays, united to form a straight edge with "picots."

The industry is believed to have been first founded by Huguenots, and encouraged by Henry IV. and Sully, but no Lace of great artistic pretension was ever produced.

\section{LILLE.}

Lille has been a French town since the treaty of Aix-la-Chapelle in I668; its productions should therefore be properly included among French Laces, though in character they are more nearly akin to those of Flanders.

In appearance there is indeed a strong resemblance to Mechlin; the special difference between the two is in the character of the "réseau." That of Lille Lace is known as "Fond simple" or "Fond clair." It is made of two threads only, and these simply crossed, not plaited, at their junction (see Fig. 6, Illustration II.) ; by this peculiarity Lille Lace can be always recognised. The pattern is outlined with a "cordonnet" of flat untwisted coarse thread. The edge of the Lace is usually quite straight, not scolloped or 
wavy, and oval openings are left in the pattern near the edge and filled with ornamental "à jours." The "réseau" is often sprinkled with small square dots.

\section{CHANTILLY.}

Though the silk Lace of France is mostly known under this name, yet its manufacture was extensively carried on at Caen, Bayeux, and Le Puy, as well as at Chantilly.

It is made both in black and white silk, and its distinguishing peculiarity is the use of the six-pointed star "réseau," the "Point de Paris" already mentioned, also known by the name of "Fond Chant," an abbreviation of Chantilly. (See Fig. 8, Illustration II.) It is generally used in conjunction with the "Fond simple" of Lille. The pattern of Chantilly Lace is outlined with a "cordonnet" of a flat untwisted silk strand.

\section{BLONDE,}

also made in the same districts, has a "réseau" of the Lille type made of fine twisted silk, while the "toile" is worked entirely with a broad flat strand, producing a very attractive glistening effect. The name "Blonde" originated from the use of écru instead of bleached silk, hence "blonde" or flàxen. 


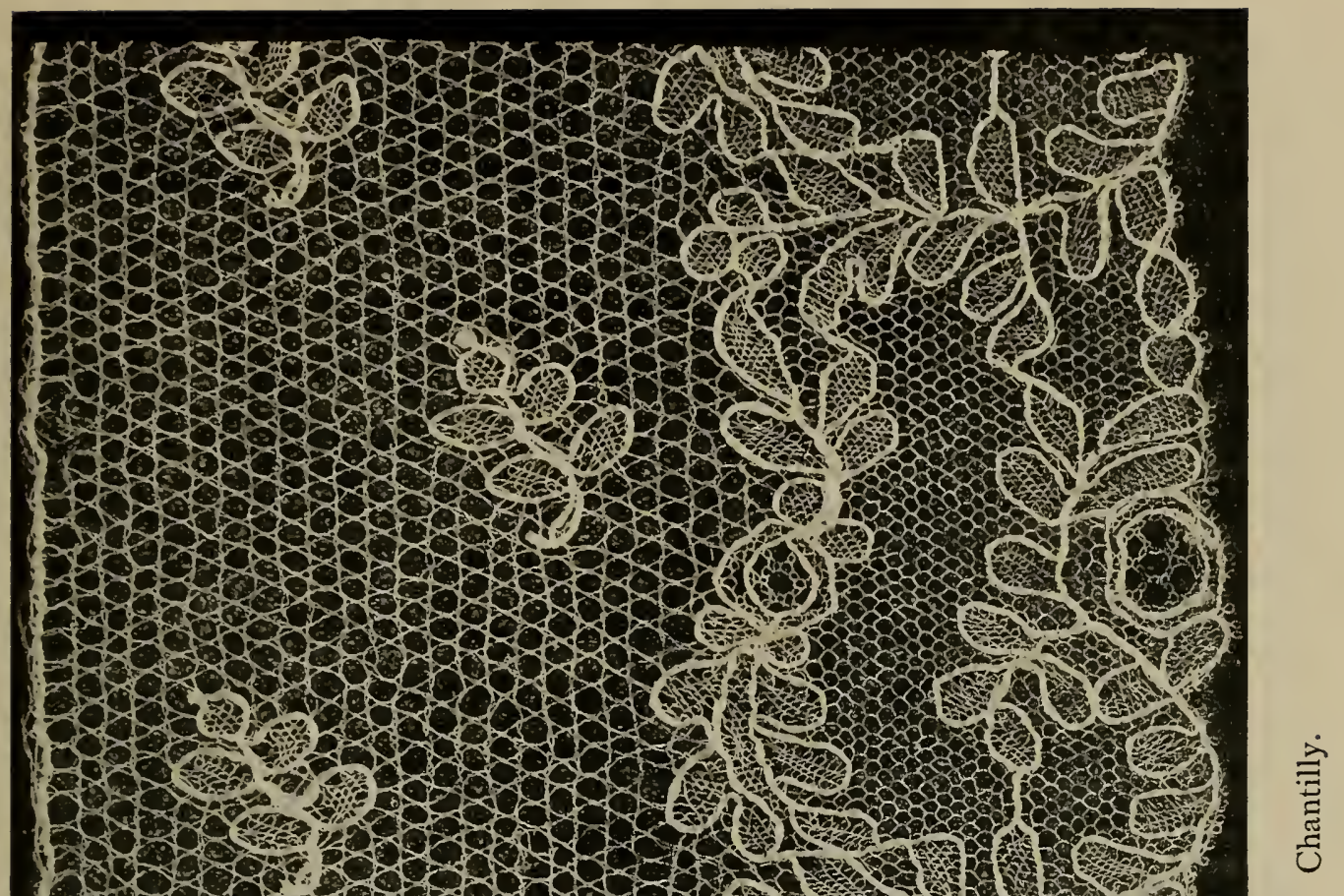

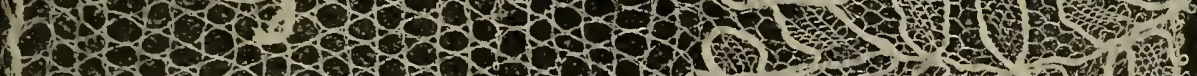

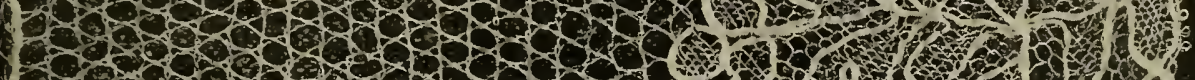

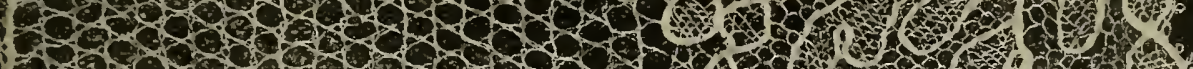

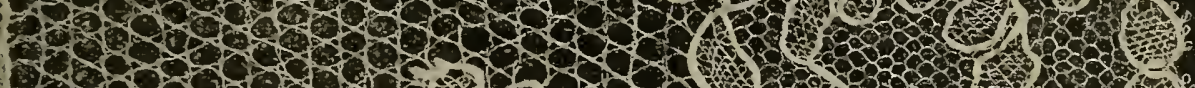

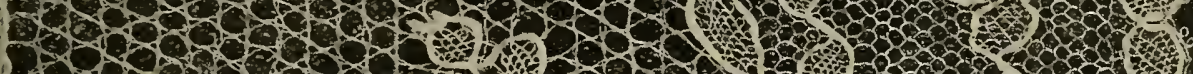

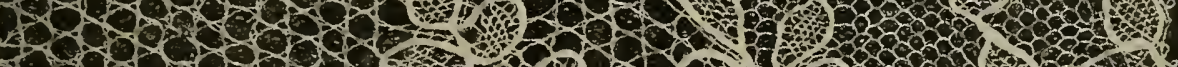

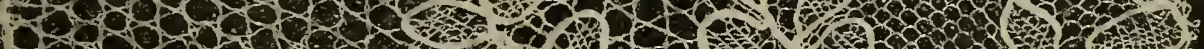

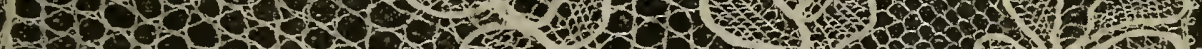

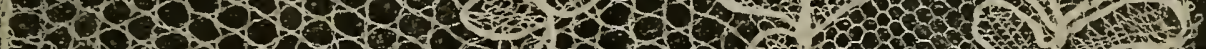

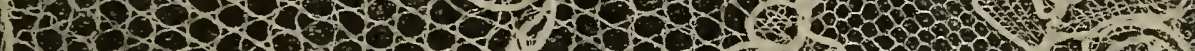

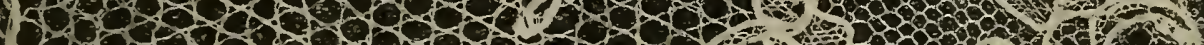

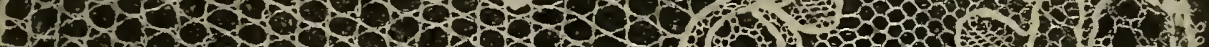

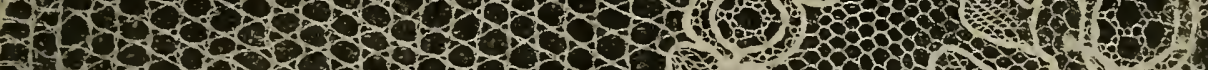

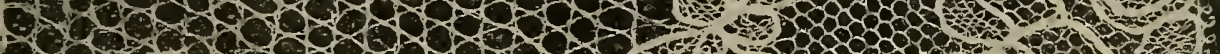

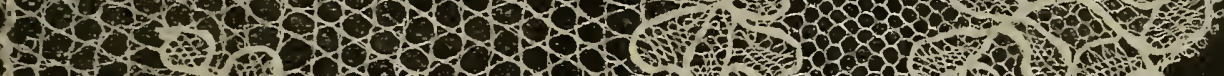

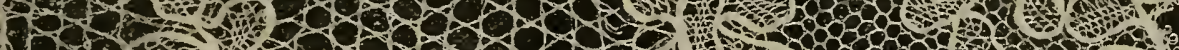

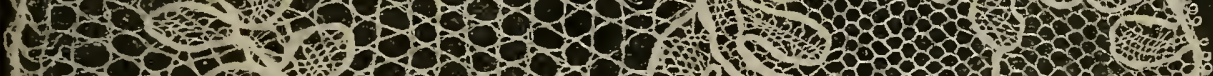

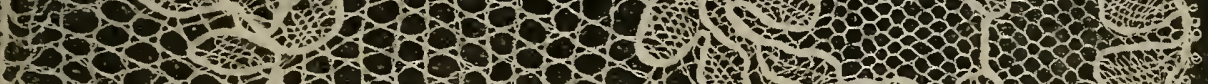

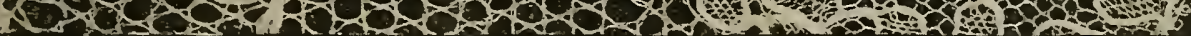


The manufacture of silk Lace at Chantilly and in the neighbourhood was established in the seventeenth century by the Duchesse de Longueville, and owing to her patronage and also probably to the vicinity of Paris it became for a time very popular. At the Revolution the demand for it, of course, at once ceased, and not only so, but being looked upon as royal protégés the unfortunate lace-makers were involved in the ruin of their patrons, and most of them perished by the guillotine. During the Empire, however, Chantilly and also Blonde came again into fashion, and since that time the demand for black silk Blonde for Spanish mantillas alone, has kept up the prosperity of the trade, which, however, is by no means confined to any one town, but flourishes throughout the province of Calvados.

\section{OF OTHER FRENCH PILLOW LACES.}

Normandy, during the seventeenth and eighteenth centuries, was a very important district for Pillow lace-making in France, Valenciennes at the time forming part of Flanders.

The picturesque head-dresses of the peasant women no doubt encouraged the manufacture. In 1692 , in Dieppe alone, four thousand women were employed 
in lace-making, and at Havre, Honfleur, Bolbec, Eu, and Fécamps the trade was also in a.very flourishing condition. The Lace produced was of a simple character, much resembling the modern Valenciennes edgings; it is often mentioned in inventories and letters of the day as being used by the upper classes, especially as trimmings for under-linen. But the Revolution passed over this district as elsewhere like a destroying blight, and the lace-making trade was for a time utterly extinguished. In 1826 some nuns attempted to revive the manufacture, and a Lace school was started at Dieppe with some success. The kind of Lace is, however, unfortunately of all others the easiest to imitate by machinery; indeed, only workers themselves, it has been said, can detect the very slight difference that exists between ordinary Valenciennes edging, as made on the pillow, and the best that is produced by the loom. Under these circumstances, as purchasers will naturally always gravitate to the cheapest market, it is no wonder if hand-work, of necessity more laborious, and consequently more costly, cannot be made remunerative. 


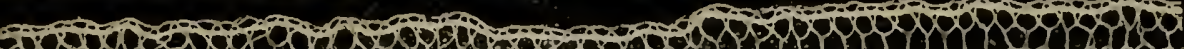

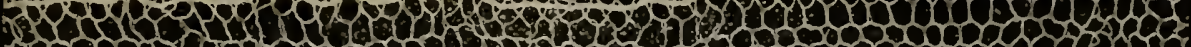

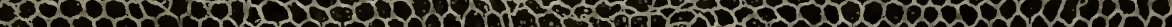

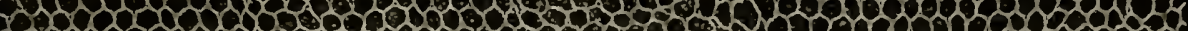

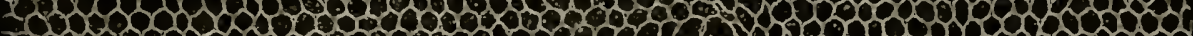

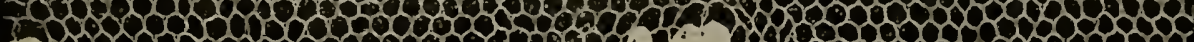

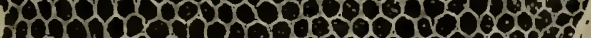

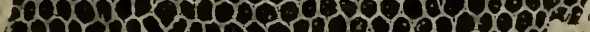

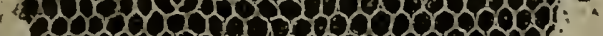
- 000000000000000

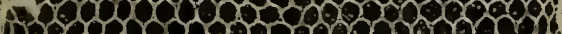

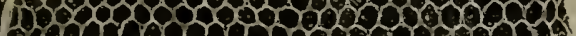
1000 dron

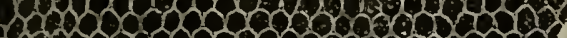

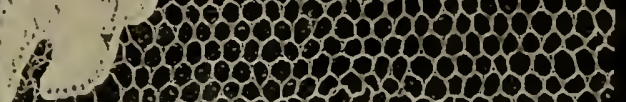
- 00000000000000

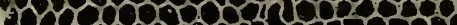

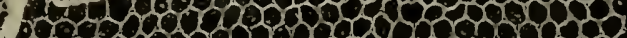
(1)

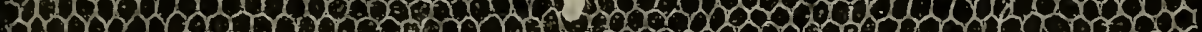

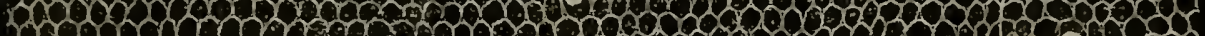

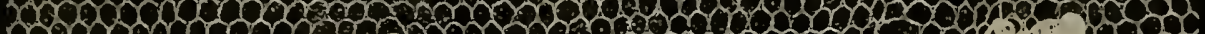

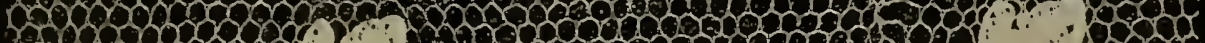

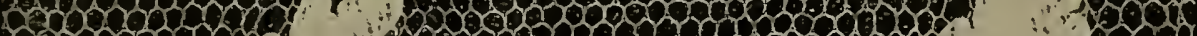

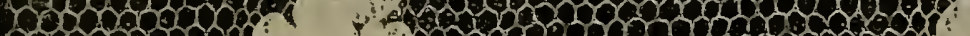

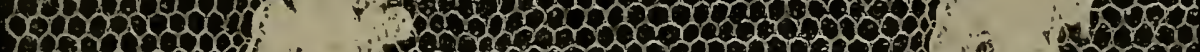
500000 :

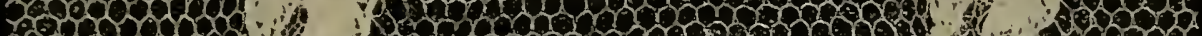

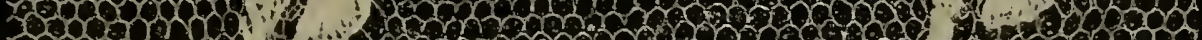

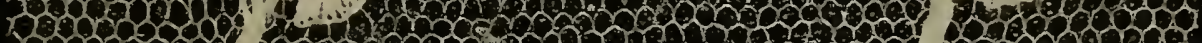

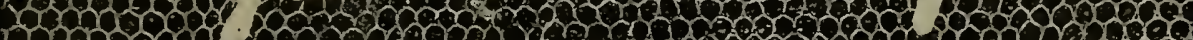

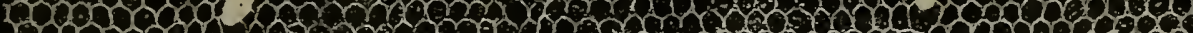

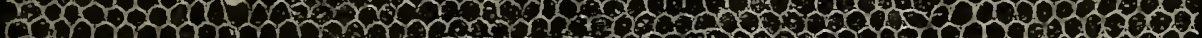

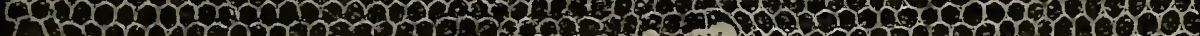

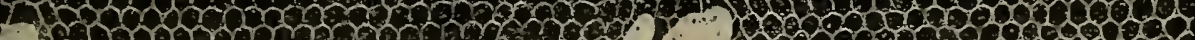

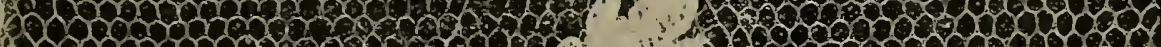

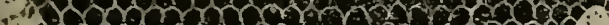

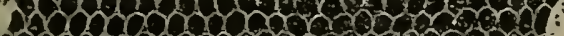

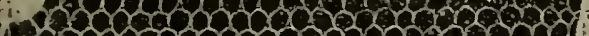

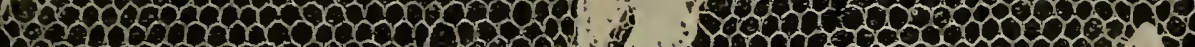

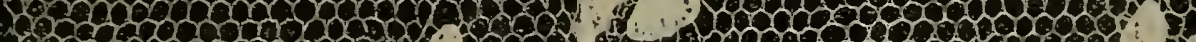

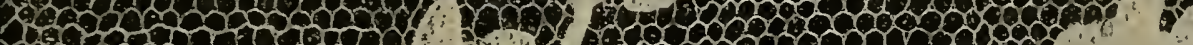

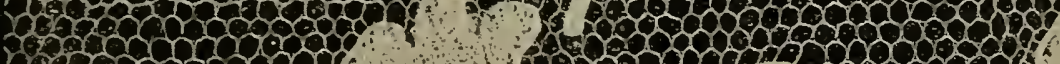

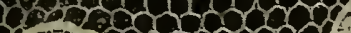
y nomorox.

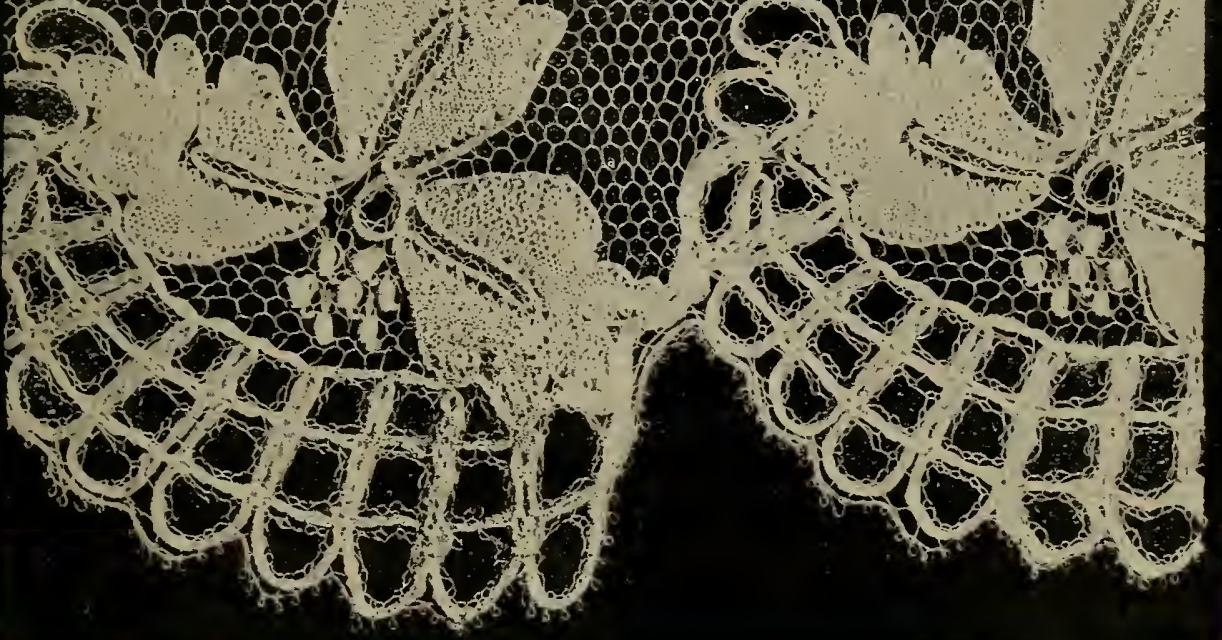

Blonde. 

Mechlin.

\section{CHAPTER VI.}

\section{OF FLEMISH LACES.}

REVERSING what we have seen to be the case with Italian Lace, the earliest Flemish Lace was undoubtedly made on the pillow, though as to whether the Art originated in Flanders or was imported from Venice, there is great difference of opinion. The arguments on both sides have been stated on page 67 . But some further light seems to be thrown on the subject, when the character of the early Flemish Lace is observed. According to the opinion of most writers, borne out by the chronological arrangement of the catalogue of the South Kensington Museum, the earliest Lace made in Flanders was of the kind known as Pillow Guipure. The pattern is made as of tape in a flowing Renaissance $R$ 
style, sometimes connected by "brides," sometimes altogether without "brides," when the points of the pattern touch each other.

There are many specimens of this Lace in the Museum so nearly like Italian Lace of the same kind, that the description there given of them is "Flemish or Italian." Two specimens are here shown in Illustration XXIX. of this Lace, and in these specimens at any rate a distinction can be observed which seems to mark them as Flemish. The thread used is much finer, and at the same time the work is looser and less firm than that seen in acknowledged Italian Pillow lace. However that may be, no one accustomed to Italian design can look at them without feeling sure that the inspiration of such Lace was certainly that of the Italian Renaissance, even though produced in Flanders, and if so, then the natural conclusion will be that such Pillow lace was in its origin Italian.

Thus much has been said, in order that the student may not be perplexed when finding Lace of undoubted Italian character attributed with good evidence to Belgium.

In Flanders, as elsewhere, Pillow lace "à brides" was antecedent to that made with the "réseau" ground. In specimen Fig. I one can almost see 


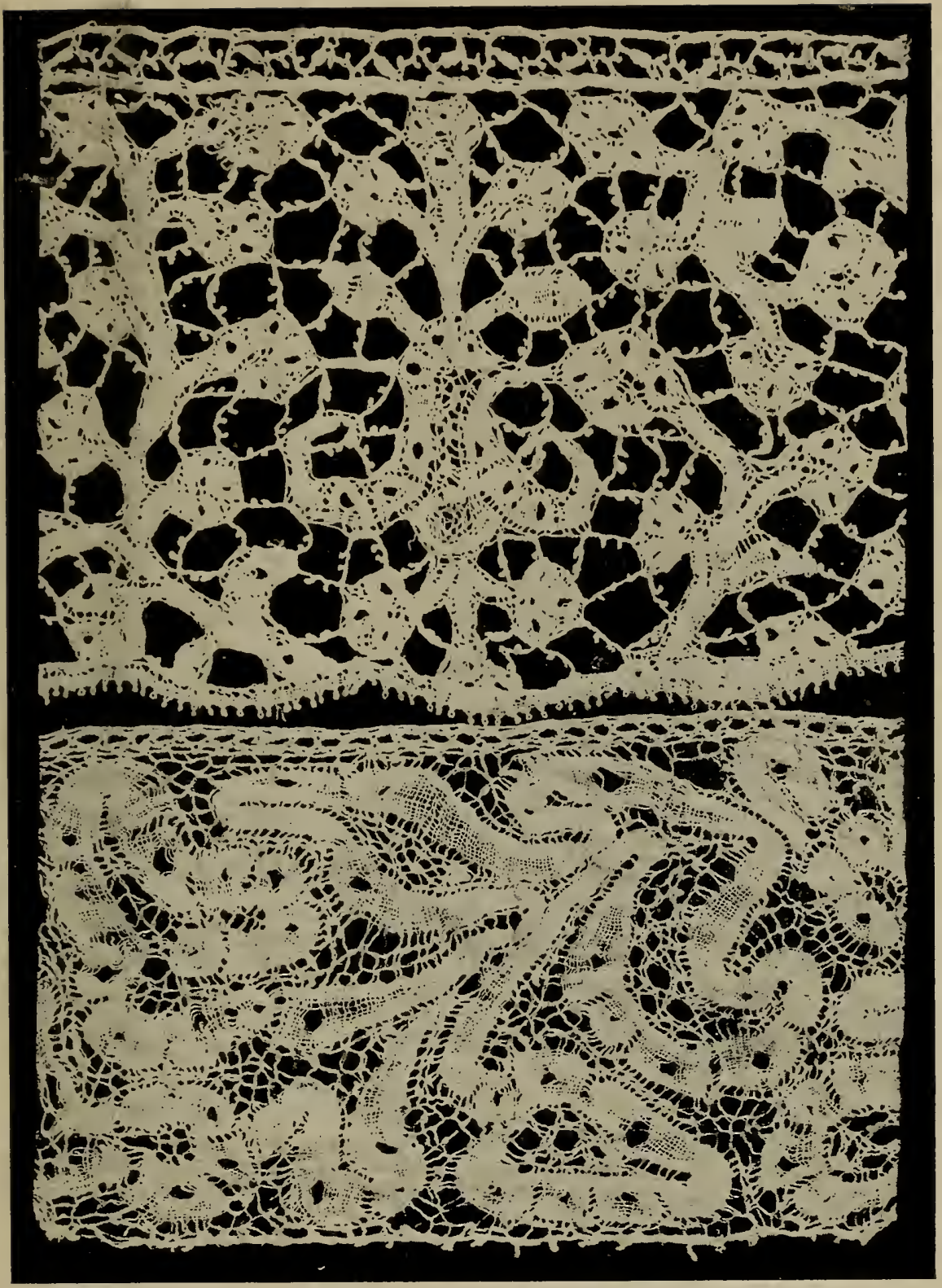

Flemish Pillow Lace (two specimens). 



\section{ORIGIN OF “RÉSEAU” GROUND}

how the one was developed out of the other. The pattern was too loose to admit of large open spaces, and as it was easier held together by many ties than by few, these interlaced, and naturally fell into regular arrangement, foreshadowing the mesh of the future "réseau."

The exact time at which this was fully developed seems uncertain. Portraiture in England, at least in this case, is of little or no assistance, owing to the vicious taste of the day which induced Sir Peter Lely and others to* represent their sitters as clraped in loose floating masses of blue or white satin, arranged in a supposed classical but impossible manner, and fastened on the thigh or the shoulder with an equally impossible jewel. But fortunately Art in Holland was less inaginative; and in a portrait of Fräulein Verbiest, by Gonzales Coqués, we see Lace with a "réseau" ground very clearly depicted. Coqués died in I684; the invention therefore must have been anterior to that date.

Mr. Alan Cole, whose short introduction to the catalogue of Lace in the South Kensington Museum is an admirably clear exposition of the subject, is of opinion that "the origin of 'réseau' grounds may be considered to lie first in the use of the net ground for 'Lacis' or Darned netting, the 'Punto a maglia 
quadra,' for which Vinciolo made many designs" (the pattern books alluded to in a preceding chapter; see p. 35). "He was in the employment of the French Court towards the end of the sixteenth century, and at this time the early form of Pillow lace was being produced, and as it proceeded and became more and more developed, the making of meshes in small series of twos and threes also developed" (see Fig. 2, Illustration XXIX.) "and expanded into larger spaces filled with 'réseau.' It seems likely that this development was stimulated by the contemporary production of the Darned net-work, which the lace-workers would be ambitious of reproducing on the pillow."

The earliest "réseau" grounded Lace made in Flanders had a large irregular mesh, and was called "Fond de brides."

\section{BRUSSELS PILLOW LACE.}

This has, all along, retained a trace of its origin from Pillow Guipure, in that like its Genoese original, and unlike other Flemish Laces, it is not made in one piece on the pillow, but the pattern is first made by itself, and the "réseau" ground is worked in round it afterwards. The peculiarity is easily recognised; 
for in consequence of the way in which it is worked, the long threads that form the "toile" of Brussels Lace of all dates always follow the curves of the pattern, whereas with other Flemish Laces in which pattern and "réseau" are made together in one piece on the pillow, however varied the forms may be, these threads are found to run parallel to the edge of the whole length of the Lace, and to pass across through the pattern into the "réseau" ground. (See diagram.)

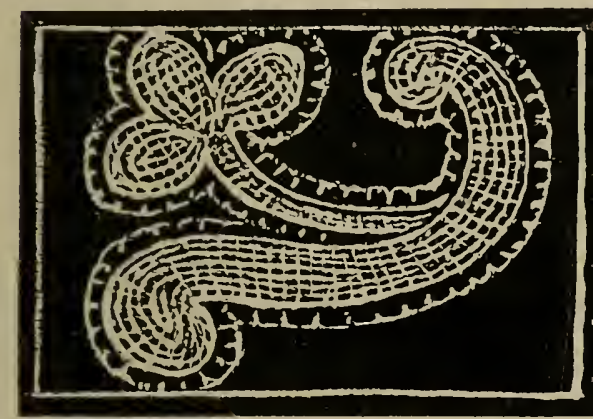

Brussels.

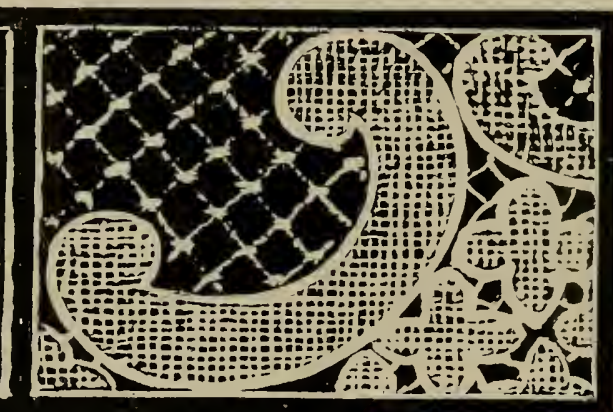

Mechlin.

Here we have the first peculiarity by which Brussels Pillow lace can be recognised. Secondly, it is to be noticed that the "réseau" of Brussels Lace, as seen through a magnifying glass, has a hexagonal mesh, of which two sides are made of four threads plaited four times, and four sides of two threads 
twisted twice. (See Fig. 3, Illustration II.) Thirdly, Brussels Pillow lace has two sorts of "toilé"; one, the usual woren texture as of a piece of cambric; the other a more open arrangement of the threads, having very much the appearance of the Fond Chant "réseau." (See Fig. 2, Illustration II.) This is used with great effect to represent shading in the production of flower forms, especially in modern Lace. Fourthly, the pattern of Brussels Lace is not outlined with a "cordonnet," but a little line of openwork stitches forms the edge instead. (See diagram.) Brussels Pillow lace is also distinguished by the beauty of its designs, more freedom being possible in consequence of the manner in which it was worked.

The extreme fineness of the thread in old Brussels Pillow lace is also to be noticed. It was spun, we are told, in dark, damp cellars, where only one ray of light was arranged to fall on the thread, which was otherwise almost invisible; also because in a drier air it would have been too brittle. But such hand-spun thread is now too costly for use, and machine-made thread is always substituted.

Although the characteristics enumerated above may always be recognised, yet the Brussels Pillow lace of to-day bears but slight resemblance to the manufactures of the seventeenth century. It has gone 


\section{ILLUSTRATION XXX.}

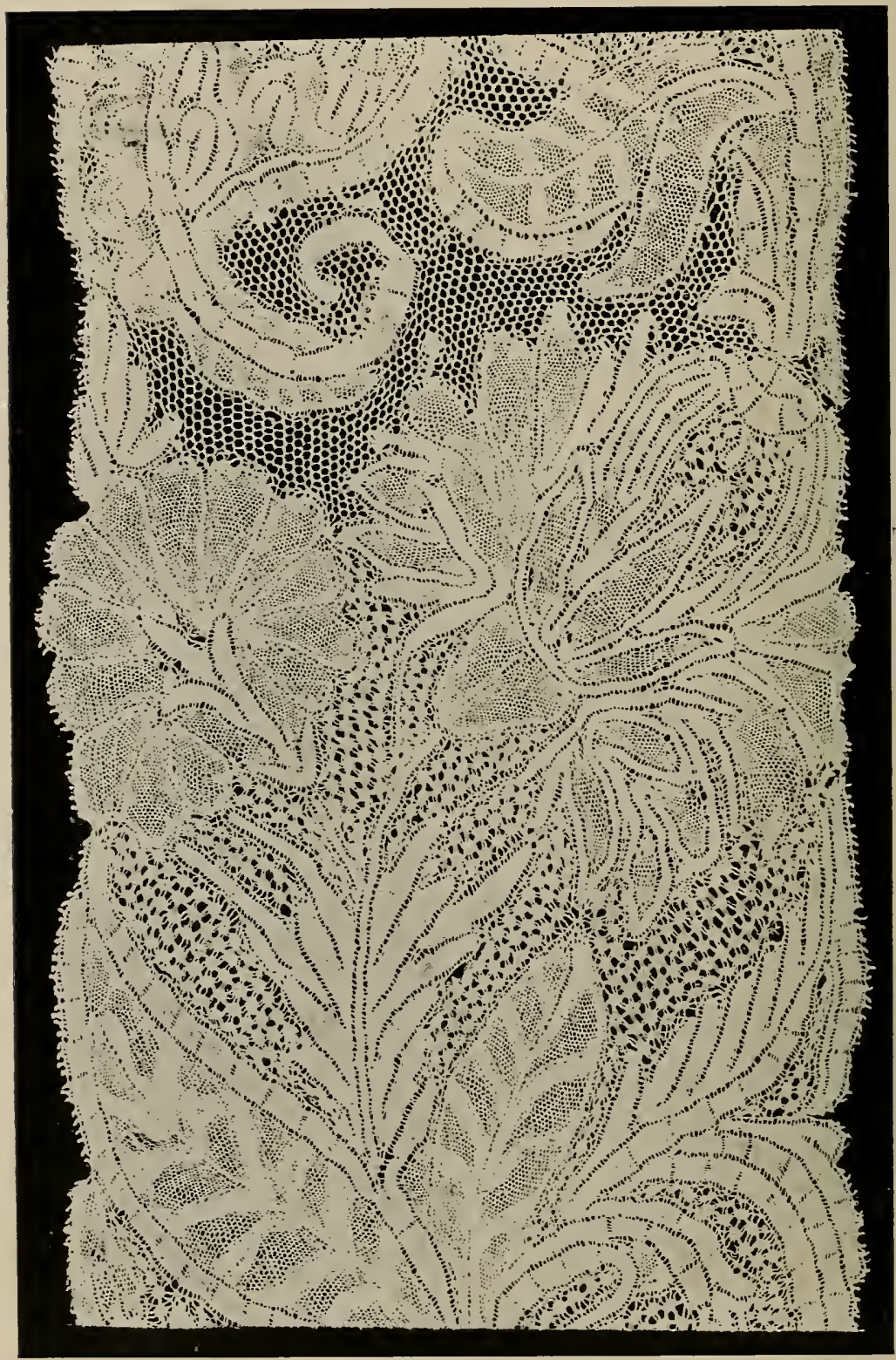

Old Brussels Pillow lace-“Point d'Angleterre." 
through many styles in pattern and make, which may be classed as follows :-

POINT D'ANGLETERRE.

On the first invention of the perfectly formed "réseau" ground, about the middle of the seventeenth century, this was worked on the pillow in the following manner: threads were hooked on to the little open edge of the "toile" of the pattern, and with these the "réseau" was worked in round the pattern to fill up the ground. "Réseau" made in this manner is called the "vrai réseau," and Brussels Lace thus worked is properly styled "Point d'Angleterre." The specimen shown in Illustration XXX. of this early style has a characteristic peculiarity, namely, the raised rib of plaited threads marking the veins of the leaves and outlining the salient parts.

It is interesting to compare this specimen with the early Valenciennes lappet shown in Illustration XXV.; though the method of execution is radically different the design is almost identical, showing the interchange of patterns which took place between various contemporary Lace manufactories. It is a lesson that one cannot altogether trust to the style of the pattern in judging of the local character of Lace.

"Point d'Angleterre" was also often made with 
open spaces left either round the pattern or in diagonal bars, and these were filled in with pillowmade "brides picotées." This Lace is called "Point d'Angleterre à brides." A very beautiful example is given in Illustration XXXI., which is further interesting on account of the fine Needle-point fillings that have been superadded. When such is the case the Lace is called "mixed Lace."

Many explanations have been given for the use of the name "Point d'Angleterre," for a Lace that is neither Point nor made in England. M. Seguin favours the theory that the Lace was of English origin, and that it was only subsequently produced in Brussels; but there seems to be but little ground for that view. The opinion more usually held is that when, about the year I660, its importation into England, as well as into France, was forbidden by prohibitive duties, the Lace merchants nevertheless found means to smuggle it across by sea to English ports and then sold it here, and exported it into France as "Point d'Angleterre." To this day all Brussels Lace is indiscriminately so called in France. The ladies of Louis the Fifteenth's Court, in the days when hoops and powder were in fashion, particularly affected this Lace. In England the protective duties were removed in 1699, and here too, during the 


\section{ILLUSTRATION XXXI.}

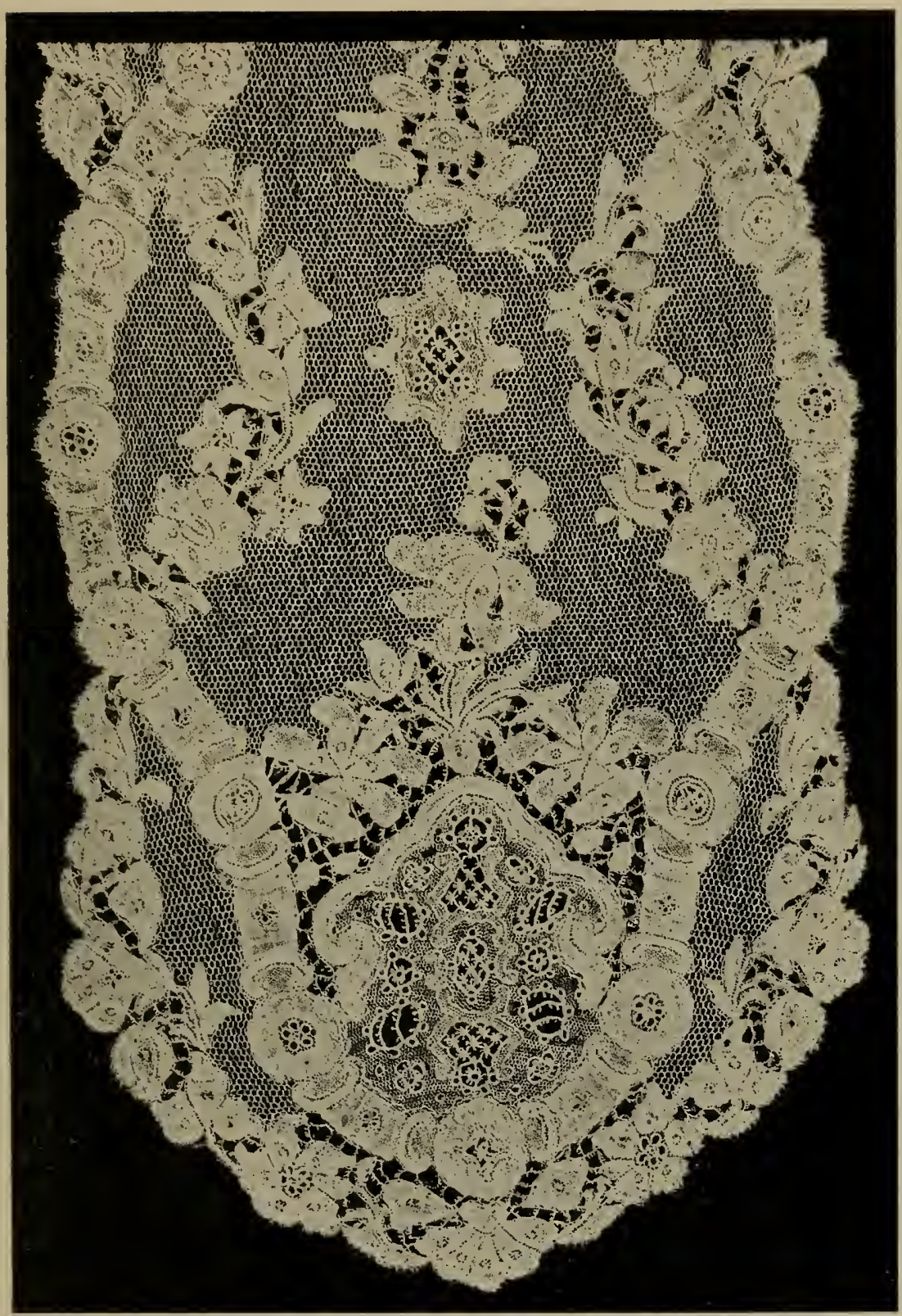

"Point d'Angleterre à brides." 

reigns of George the First and George the Second, in spite of great efforts made to encourage native lace-making, ruffles, lappets, and flounces were most admired when made of Brussels Lace. Such Lace at this time was made in pieces of considerable size, and in this case the "réseau" was worked in narrow strips from an inch and a half to two inches wide, and afterwards joined together to the required width with the needle, but so skilfully as almost to elude detection.

Brussels Lace, "à vrai réseau," continued to be produced until the catastrophe of the French Revolution, which had its effect upon this as upon all other centres of the Lace industry; but here, it was not the only cause of the decline of the Art. The invention of machine-made net had been perfected in Nottingham about the year I8Io, and from that time forward. the Brussels lace-workers adopted the plan of appliquéing their Pillow-made patterns on this comparatively inexpensive material, and the "vrai réseau" worked on the pillow is now never made except by special order for Royalty or for exhibition purposes.

Lace so appliquéd can be distinguished from that made with the "vrai réseau" by the fact that the net ground, though sometimes cut away, is often 
seen to pass behind the lace pattern, and also by the character of the network; machine-made net is composed of diamond-shaped meshes, and is made with two threads only, very tightly twisted and crossed, not plaited, at their junction, and is quite unlike the Brussels pillow "réseau" shown in Fig. 3, Illustration II.

Brussels Pillow Lace appliquéed on machine-made net is known as "Point plat appliqué." The term "Plat" is used to distinguish it from Needle-point Brussels, also sometimes appliqué. The innovation described above was very fatal to the character of Brussels Lace. The designs grew more and more attenuated and detached as the temptation was felt to spread the pattern more sparsely over the net ground. Owing to the naturalistic taste of the day also, the finely composed conventional ornament of an earlier date was abandoned in favour of representations of natural flowers. A still later but better style of Brussels Lace is the

\section{POINT DUCHESSE.}

In this the pattern is grounded entirely with Pillowmade "brides," and the "réseau" is altogether absent. The designs are necessarily more continuous than in the preceding Lace, and they are often very good. 


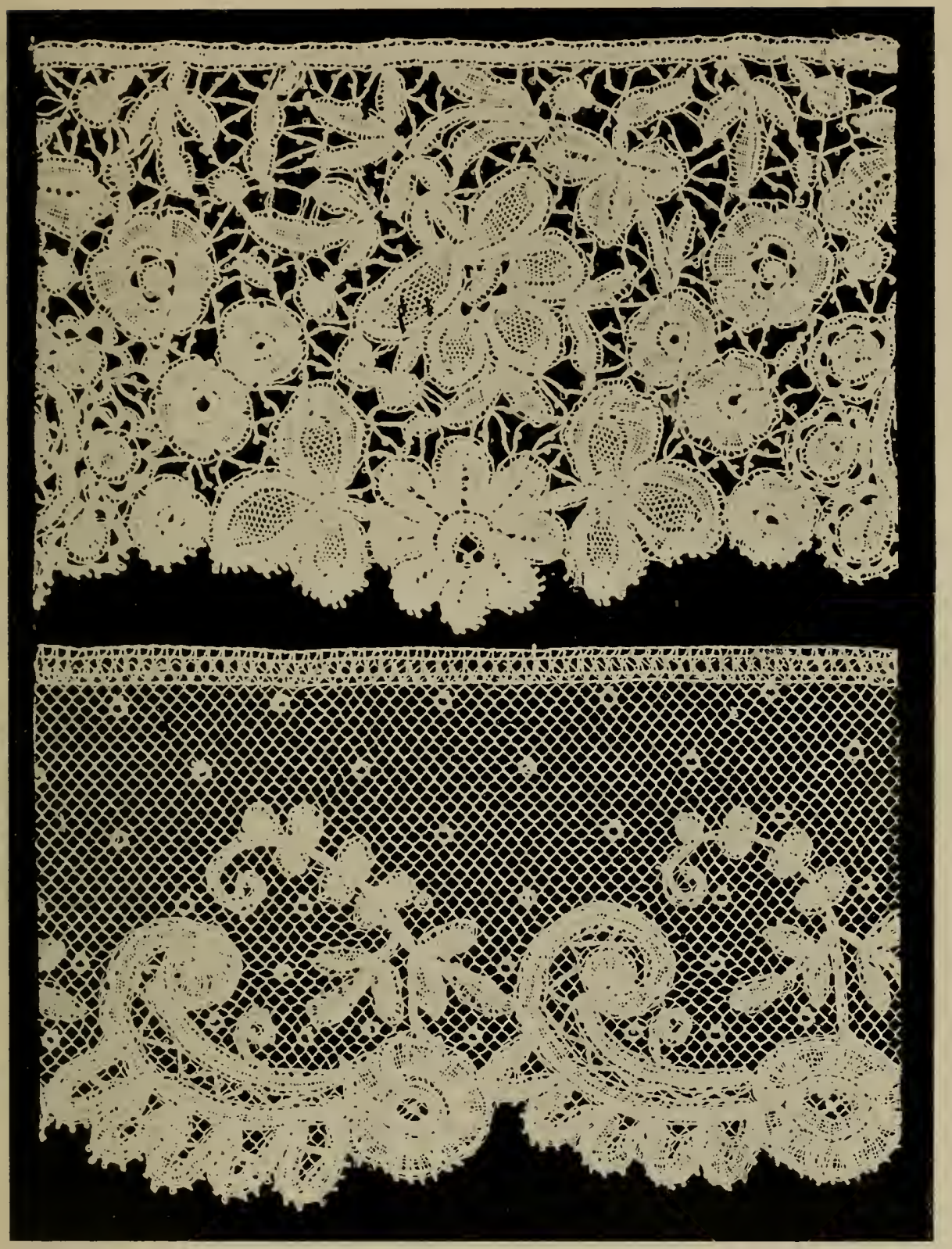

Modern Brussels.

I. Point Duchesse.
2. Point Plat Appliqué. 

The name of this Lace is of comparatively recent date, but the style itself existed earlier, under the designation of "Guipure façon Angleterre."

\section{BRUSSELS NEEDLE-POINT LACE.}

Brussels is the only Flemish centre for the manufacture of Needle-point lace.

In Flanders lace-making started from the invention or adoption of Pillow lace, and it seems evident that it was only in consequence of a spirit of emulation, and of the example set by the French lace-workers of Alençon, that needle lace-making was started at Brussels, about the year I720. A proof of its late adoption is, that Brussels Needle-point was never made with "brides" only, as we have seen was the case with the early Needle-points of Venice, and also with the work first produced in France.

It is interesting here to note how the influence of neighbouring countries and districts acted and reacted on each other. The Needle-point "réseau" of Alençon was practically a copy, with the needle, of the pillow ground of Flanders, and now in turn Flemish workers borrowed, or more probably stole, from France the secrets of Needle lace, 
including the invention originally copied from themselves.

The earliest Brussels Point very nearly resembles that of Alençon. The work is generally, however, not quite so close and firm, and the "toile'" is looser and flatter. The "cordonnet," instead of being entirely covered with button-hole stitches, as is the case with Alençon Lace, is left in an unfinished state as a strand of threads. There is also a difference in the "réseau"; in Brussels Lace it is made with a simple looped stitch, whereas in the Alençon "réseau" the loops are whipped over at their base with an additional thread. (See Figs. 2, 3, Illustration I.) This peculiarity has been continued to the present day, the "réseau " of modern "Point de Gaze" being so worked.

The style of the designs of Brussels Point is rarely of so fine a Renaissance type as in the best French Lace. The patterns are usually such as were also worked at the time on the pillow; but where patterns as well as inventions were so frequently interchanged, it is impossible to draw any certain distinction from such differences. The uncovered "cordonnet" and the simply looped "réseau" are the safest indications.

The earliest Brussels Needle-point was grounded 


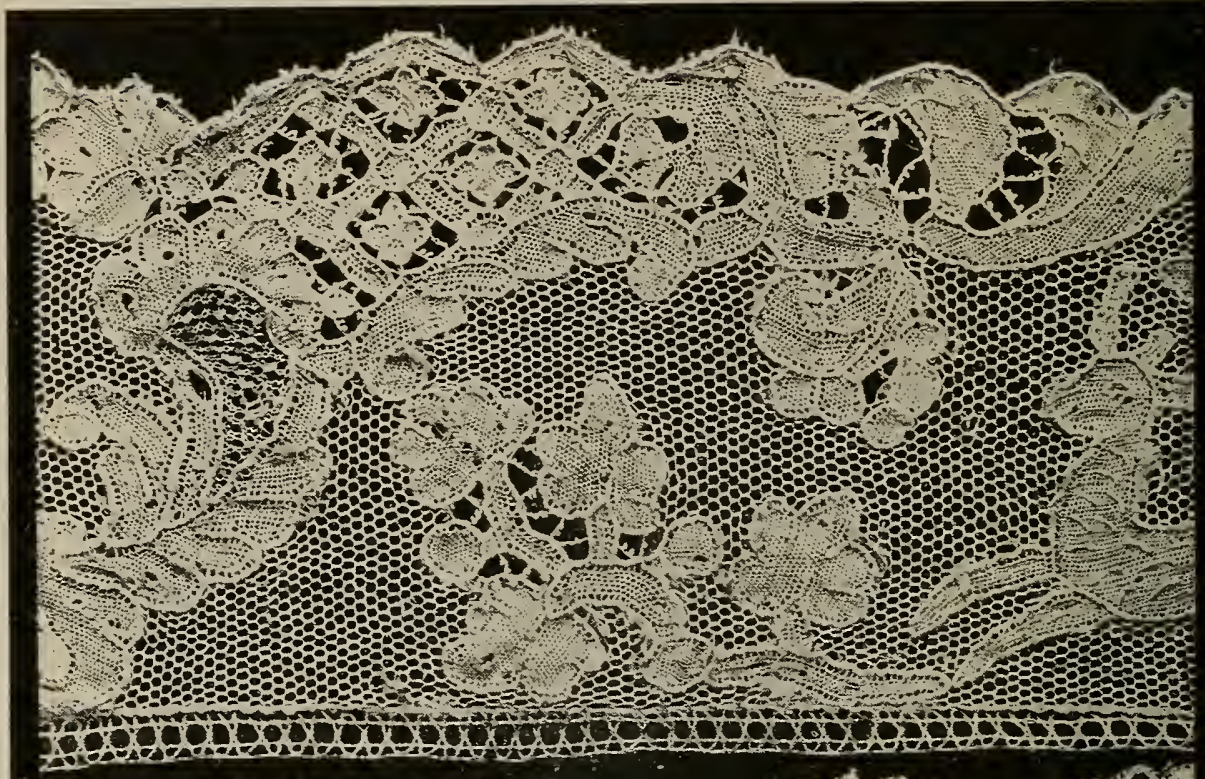

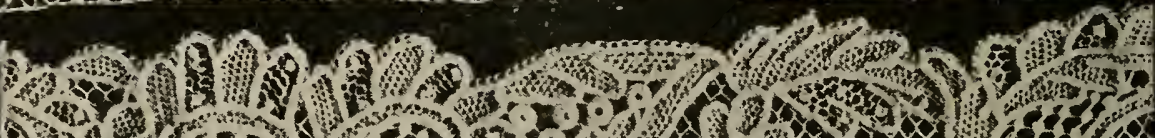

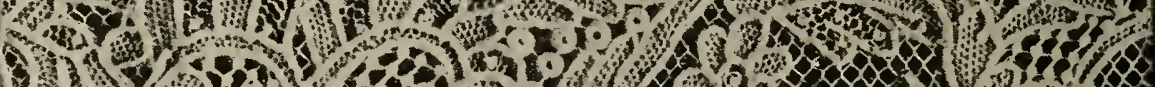
(1) 3 (w)

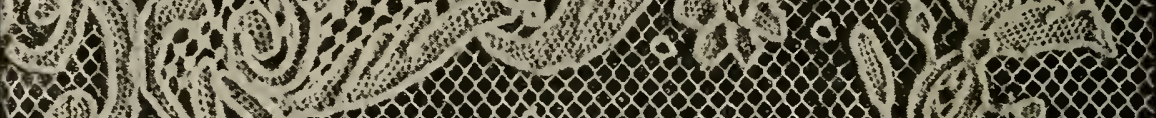

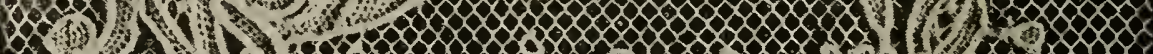

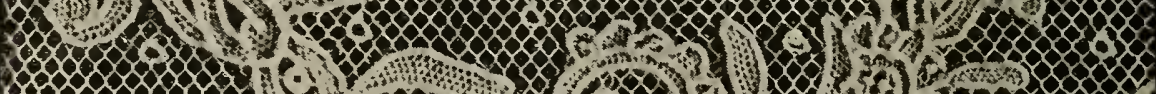

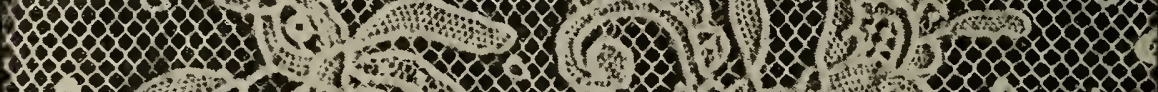

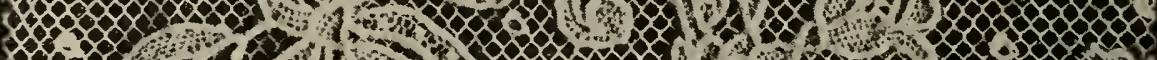

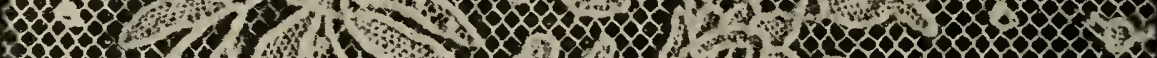

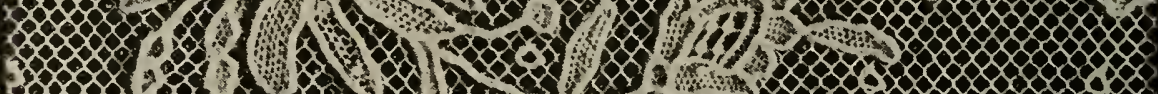

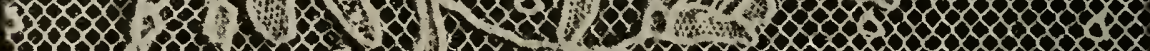

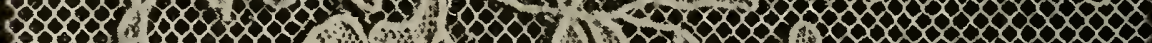

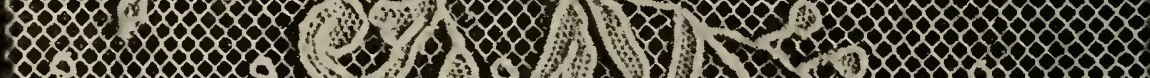

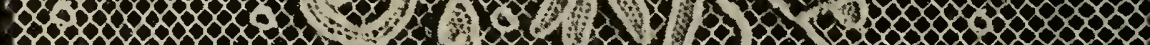

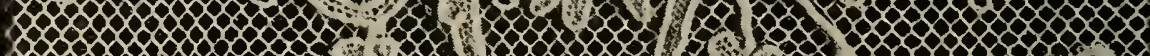

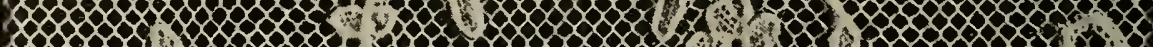

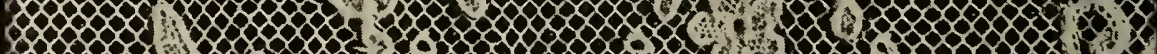

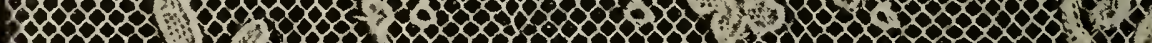

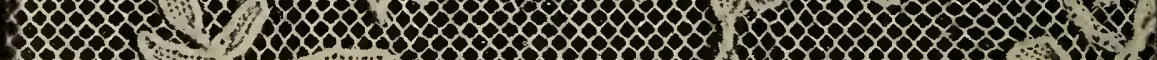
$8 \times 18 \times 1$ and

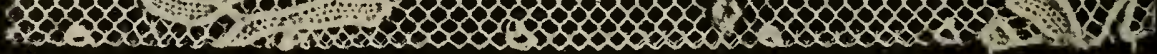

I. Old Brussels Needle-point.
2. Modern Brussels Needle-point Appliqué. 142 
with a needle "réseau," but examples of such Lace are not very common. The Brussels lace-makers were justly celebrated for their beautiful Pillow-made "réseau," and being more familiar with its practice they seem to have preferred to use it. Thus we find much of their best Needle lace grounded with the "vrai réseau" worked on the pillow, in the same way as with the "Point d'Angleterre"; this is the case with the specimen shown in Fig. I, Illustration XXXIII.

At the beginning of this century Brussels Needle lace underwent the same process of decline, and from the same causes that we have seen to have affected the Pillow lace; it degenerated into--

\section{POINT APPLIQUÉ,}

that is, the Needle lace pattern instead of being grouncled with the "vrai réseau," was appliquéd on to machine-made net; and as the demand for a less expensive style of work grew greater at the same time that labour became dearer, the patterns became more and more slender and were more thinly scattered over the ground. In Illustration XXXIII. two specimens are shown. Fig. I represents a piece of early Brussels Point grounded with the Pillow- 
made "vrai réseau," and Fig. 2 a late piece of "Point Appliqué." If for no other reason, this later style is to be deprecated on account of the quality of the net, which is always partly, often entirely, made of cotton; it shrinks the first time it is washed, causing the curves of the needle-worked pattern to become crumpled and shapeless, and if, in order to avoid this misfortune, the Lace is sent to Brussels to be cleaned, it is, we understand, only possible to do so by dipping it in white lead, with the certain result that the whole will in time turn the colour of rust.

\section{POINT DE GAZE.}

It is a pleasure to record that of late years an honest return has been made by the Brussels laceworkers to early Needle-point traditions. The beautiful modern Lace known as "Point de Gaze" is made entirely with the needle, and is grounded with its own "réseau." Partly to suit modern taste in design, and partly perhaps from economy of work when labour is so dear, the execution is much more open and slight than in the early Lace, but this very slightness is skilfully made use of to produce an extremely elegant effect; part of the "toile" is made in close and part in open stitch, giving an appearance of 


\section{IlLUSTR.jTION XXXIV.}

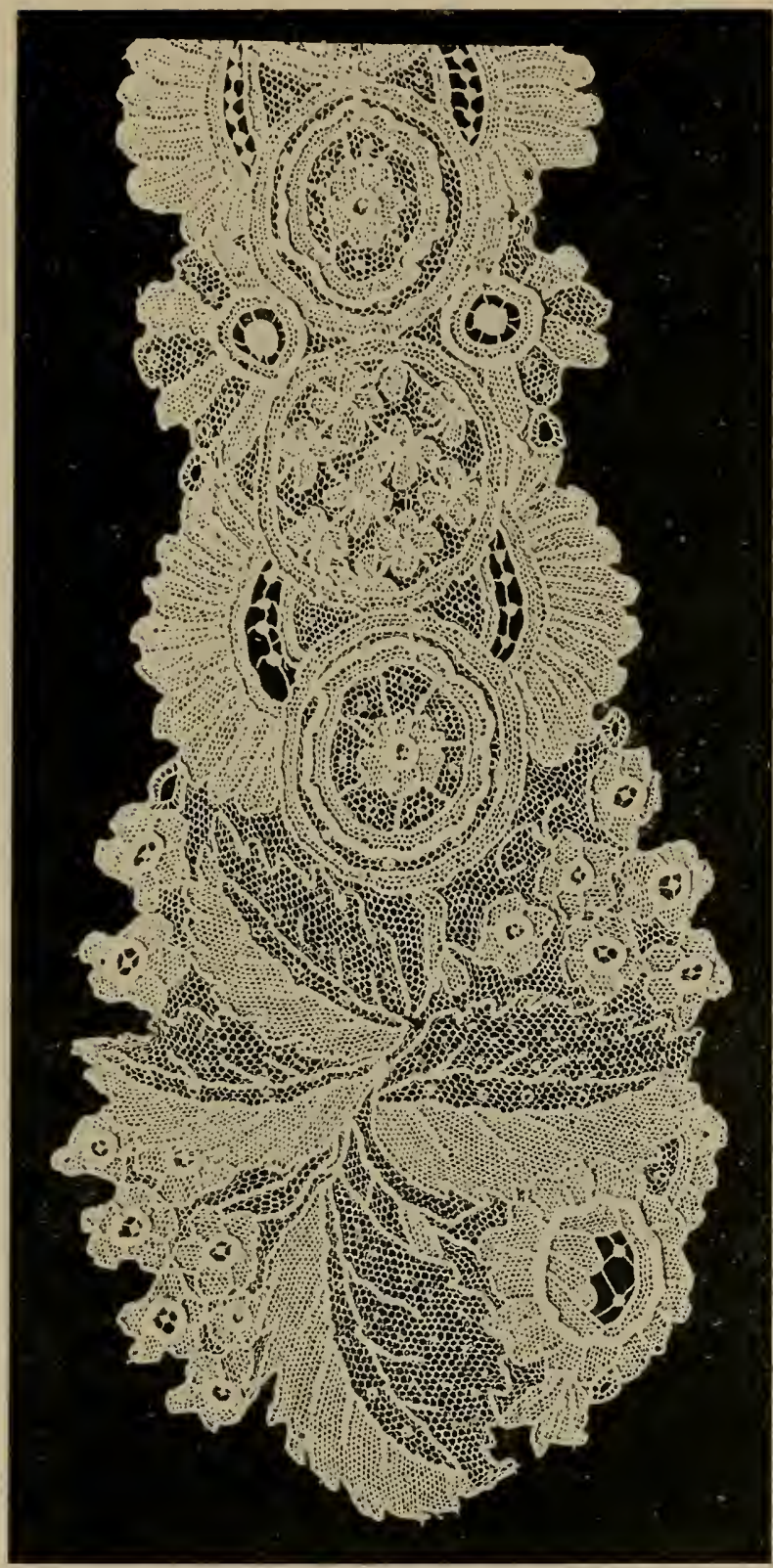

Modern Brussels Needle-point-"Point de Gaze." 

shading; and the open parts are very prettily enriched with dotting. If to those who delight in the soft richness of the work of former times the execution of the "Point de Gaze" seems somewhat thin and loose, and the style of the patterns rather too naturalistic, it must be allowed that to many, the result produced is a certain lightness and delicacy to which the old Brussels Point did not attain; and one must be glad that when an almost unlimited demand for cheaper goods is in every direction flooding the market and pressing down the price at which Lace can be sold, the Brussels craftsmen should have taken up again their old Art and have been able to produce so beautiful a fabric.

\section{OF FLEMISH LACE.}

The best known Flemish Laces, other than Brussels, are: Mechlin, Binche, Ypres, and Antwerp.

All these belong to that class of Pillow lace which is made in one piece on the pillow, the same threads passing across the whole width of the Lace and forming both the ground and the pattern. (See diagram, p. 127. ) 


\section{MECHLIN (Fr. MALINES).}

All Flemish Lace was at one time classed under this name, but the earliest that can be distinctively so called was made with a "réseau" ground about the year I720. The special characteristics of Mechlin Lace are : first, the "cordonnet" of a flat silky thread which always outlines the pattern; and, secondly, the hexagonal mesh of the "réseau." It is made of two threads twisted twice on four sides, and four threads plaited three times on the two other sides; thus the plait is shorter, and the mesh consequently smaller than that of Brussels Lace. (See Illustration II., Figs. 3, 4.) This Lace is sometimes grounded with an ornamental "réseau," instead of one in the usual hexagonal shape, called "Fond de neige" or " Eil de perdrix," and also occasionally with the six-pointed "Fond Chant," but these varieties are not common.

In the earliest Mechlin Lace the style of designs very much resembles that of Brussels, though rather heavier and less graceful; it is needless to repeat, however, that though the patterns may be alike, the totally different method of construction always marks the difference between the two. (See.p. I 27:)

The quatrefoil flower pattern seen in Illustration 


\section{IILUSTRATION XXIY.}

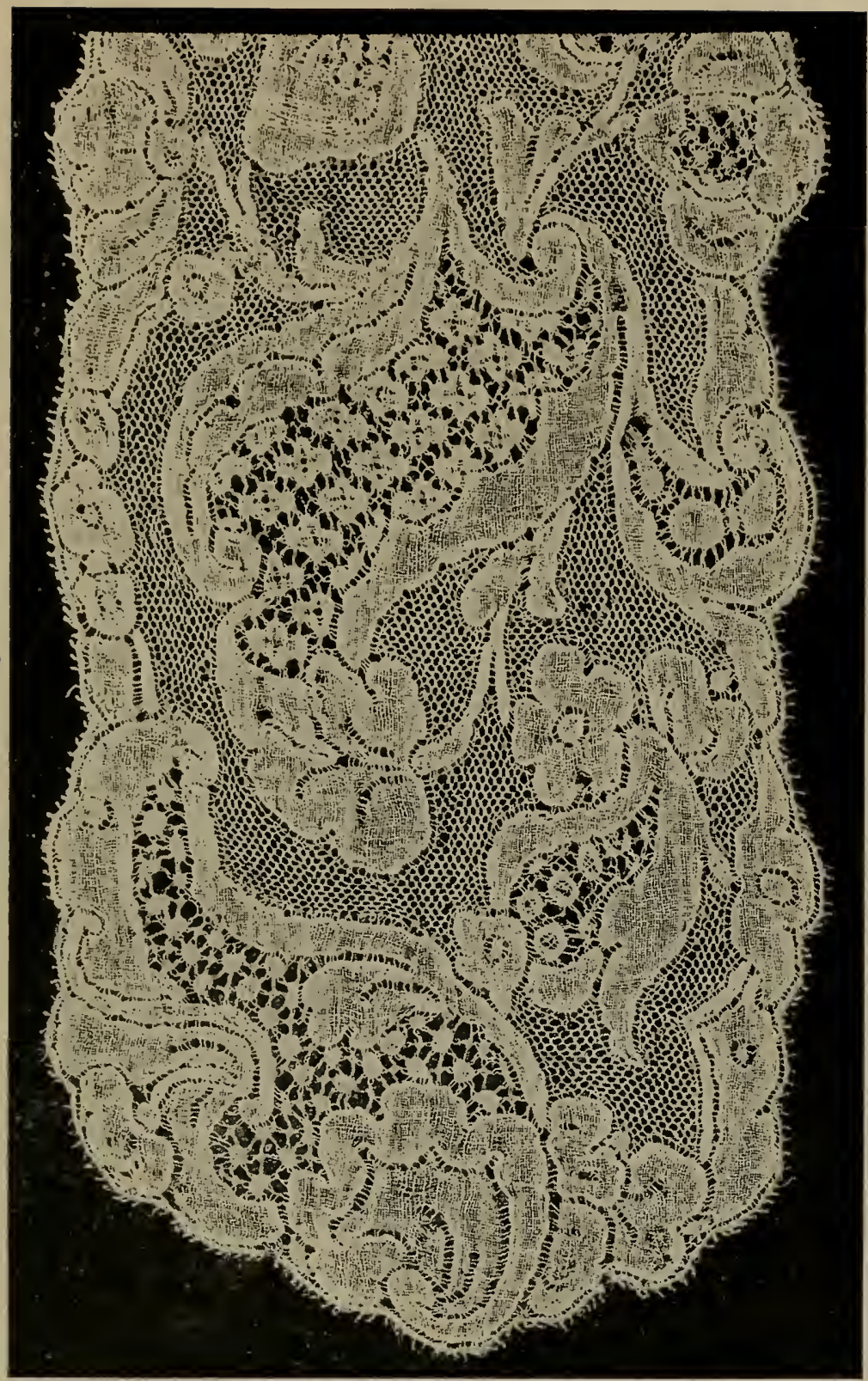

Early Mechlin. 
$\mathrm{XXXV}$, as a filling to the spaces of the conventional scroll-work, is very characteristic of this period.

Illustration XXXVI. shows another imitation of Brussels designs. In this specimen of "Malines à bricles" the peculiarities of "Point d'Angleterre" are very closely followed, even to the open spaces filled in with "bride"-like "à jours."

But Mechlin, when at the height of its popularity, had evolved a style of its own. The pattern, more or less floral, always formed the edge of the Lace, and the "réseau" ground was sprinkled with small flowers or spots. The rose and the carnation, two very favourite flowers with lace-makers, were represented with singular fidelity. The Lace of this period is perhaps one of the prettiest in existence. It is so light and soft, the pattern and the "réseau" are so well balanced, and the designs so graceful, that it well deserves its title of the Queen of Laces. The fine Indian muslins which became the fashion at the court of Marie Antoinette could support no heavier ornament, and accordingly we see it abundantly introduced in the portraits of the day.

In England it has been always a favourite, and few are the collections of old family Lace in which some beautiful specimens are not to be found.

But this Lace, like all others, had its day of decline 
in taste as well as in popularity. The. French Revolution was a blow severely felt, and when the lace trade revived under the Empire, perhaps the old patterns had been lost or forgotten, or were found too expensive for sale, and so a thinner and more meagre style of design was adopted. But the revival was not long-lived, and now the manufacture is altogether discontinued.

\section{BINCHE.}

Lace of a very fine and delicate description is attributed to this town.

Its characteristics are, that there is either no "cordonnet" at all outlining the pattern, or that the "cordonnet" is scarcely a thicker thread than that which makes the "toilé." The ground can scarcely be called a "réseau," for there are no meshes, but instead, a spider's-web-like material, closely sprinkled with small round spots or discs. It is called a "Fond de neige," and in truth really resembles snowflakes. The whole is more-like a delicate cobweb than any other work of woman's fingers.

This is one of the earliest of Flemish Laces, as is shown by the absence of any regular "réseau." The kind of work has now been quite given up, and Mrs. Palliser says that the lace-makers of Binche 

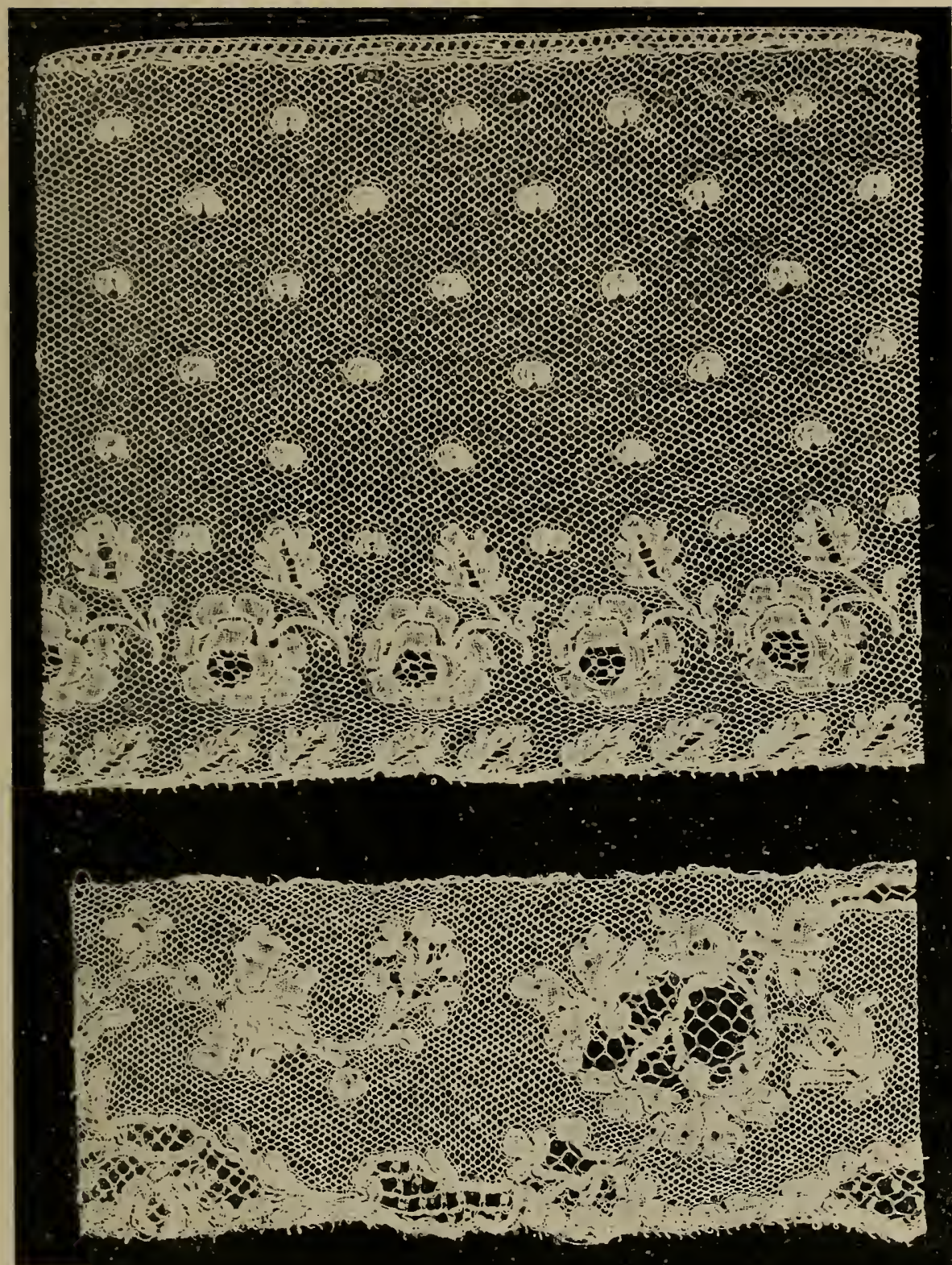

I. Early Mechlin "à brides."

2. Later Mechlin "à brides." $\mathrm{X}$ 


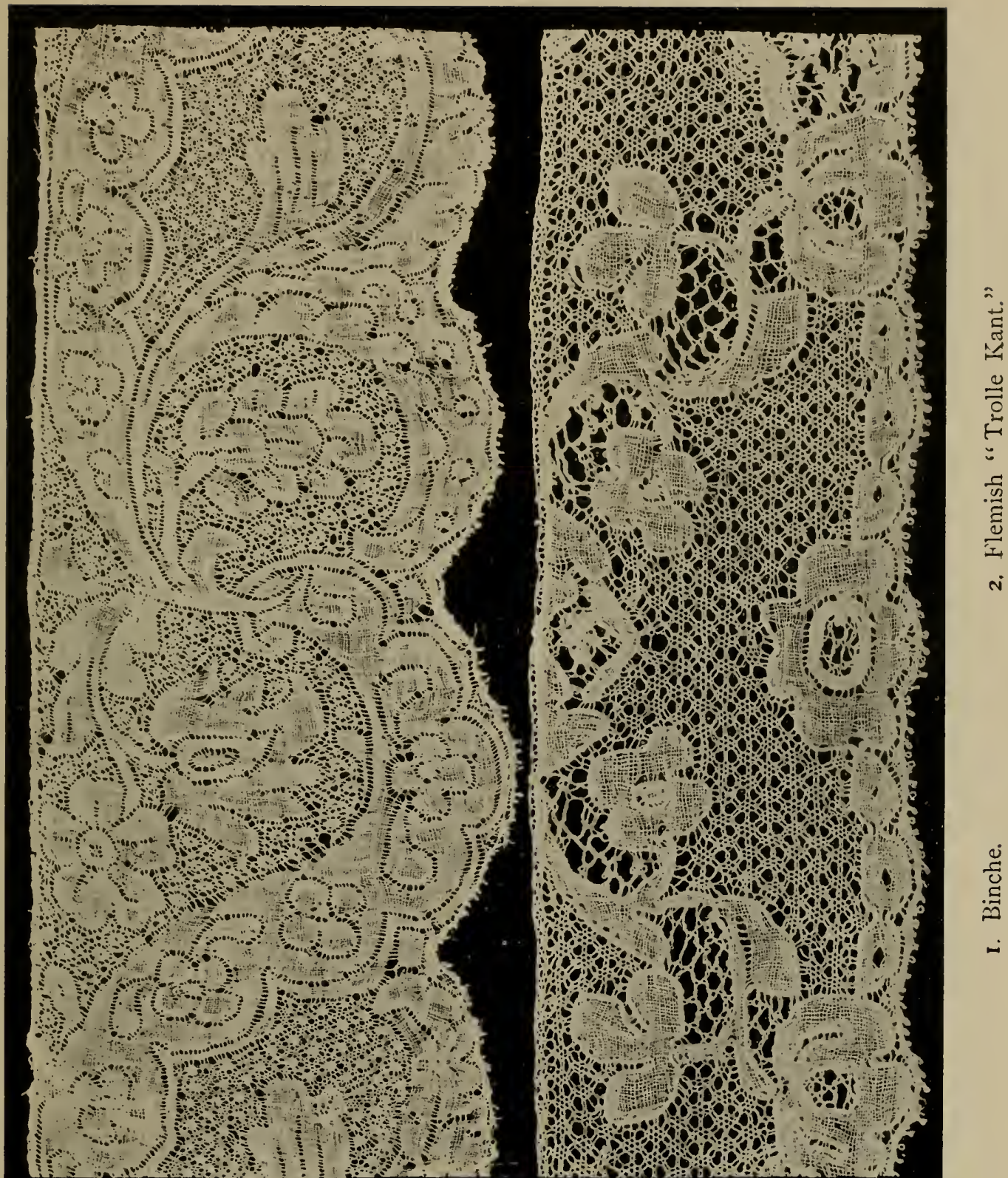

$\rightarrow 0 \% 0$ 30 ond (1)

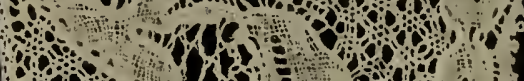

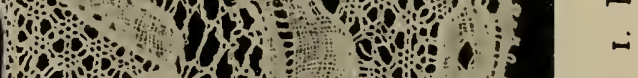

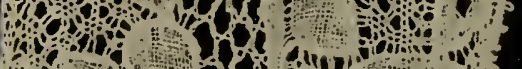

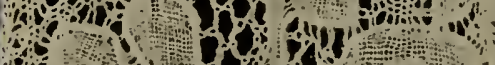

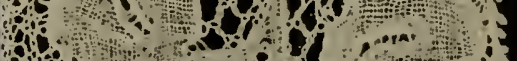
anow on

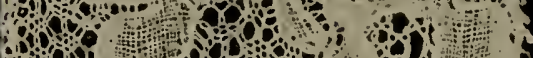

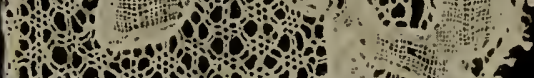
Wo 0 on on 
in her time employed themselves in making the sprigs for Brussels Point plat appliqué.

On the same illustration is shown a specimen of so-called Trolle Kant; Kant being the Flemish word for Lace, and Trolle, to judge from the use of the corresponding word "Trolly" in Buckinghamshire, signifying the coarse outlining "cordonnet." The specimen is interesting as being a rough representation of the general style of early Flemish designs.

\section{YPRES.}

As has been said on page 102, the manufacture of Valenciennes Lace, which has entirely disappeared from the place of its birth, has been continued at Ypres and in the neighbourhood. The Lace is made in exactly the same manner as was formerly the "Vraie Valenciennes," but it is inferior in workmanship, and in variety and beauty of design. Its character is too well known to require description; it need only be said here that like the old Valenciennes, the pattern is not outlined with any "cordonnet," and that the "réseau" is made with a plait of four threads, and forms a diamond-shaped mesh. 
ANTWERP.

The best known Lace made at Antwerp is the so-called "Potten Kant," or Pot lace, from the representation of a pot or vase of flowers with which it is always decorated. Some have considered this pattern to be a survival from an earlier design, including the figure of the Virgin and the Annunciation, though it does not seem certain that any such larger composition has ever been seen. The pot varies very much in size and details. The accompanying illustration shows a very handsome one, with some exceedingly well-represented carnation flowers ; but, large or small, no Antwerp woman's cap was in former days considered properly trimmed without this ornament. The Lace is usually grounded with a coarse "Fond Chant."

In various places in Flanders, besides those above mentioned, many kinds of Lace, more or less coarse, have been made, but without any such special distinction as to require separate notice; they can be usually recognised as Flemish by a resemblance to the characteristics already described, as those of the more important manufactures. 


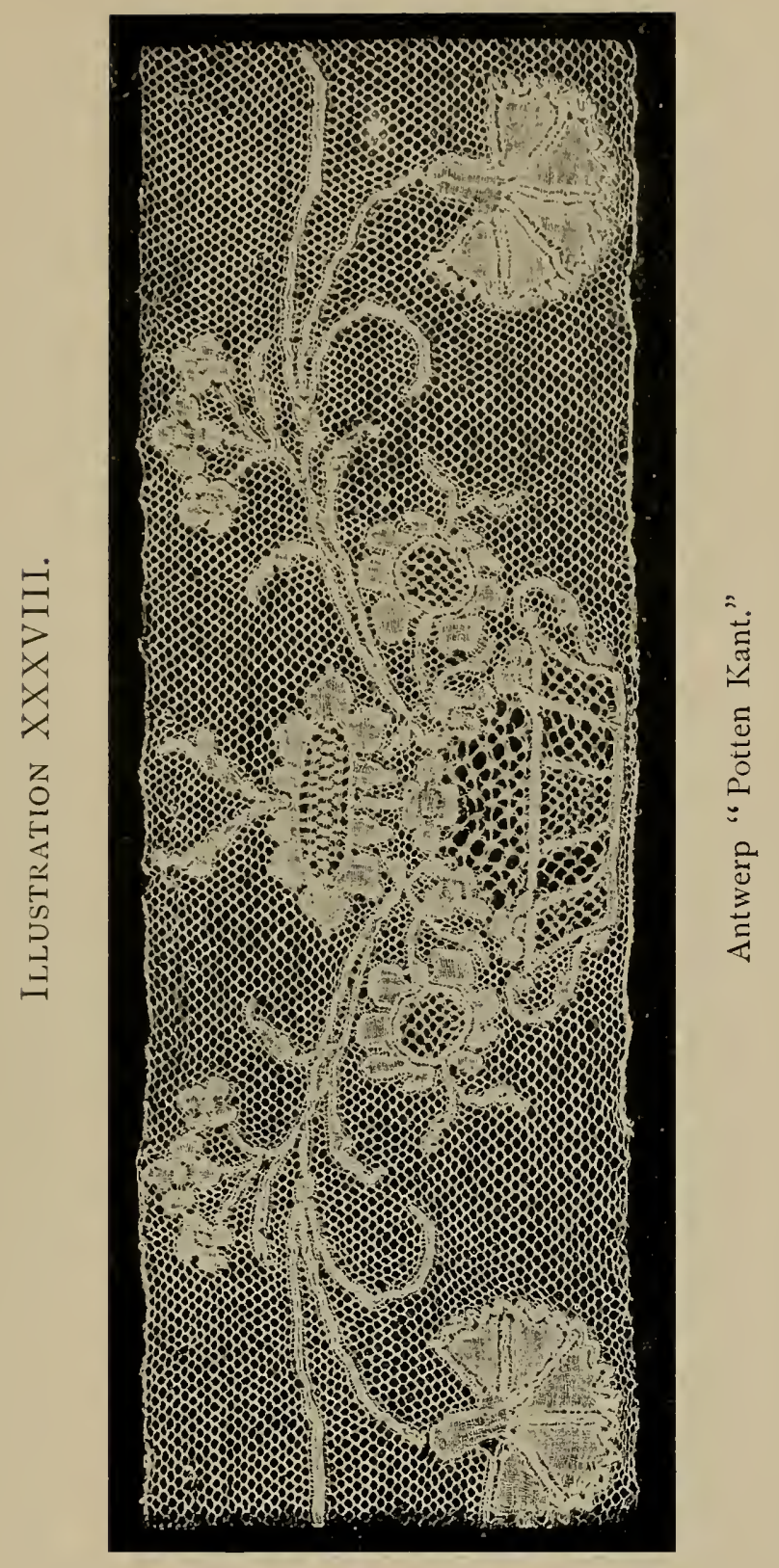





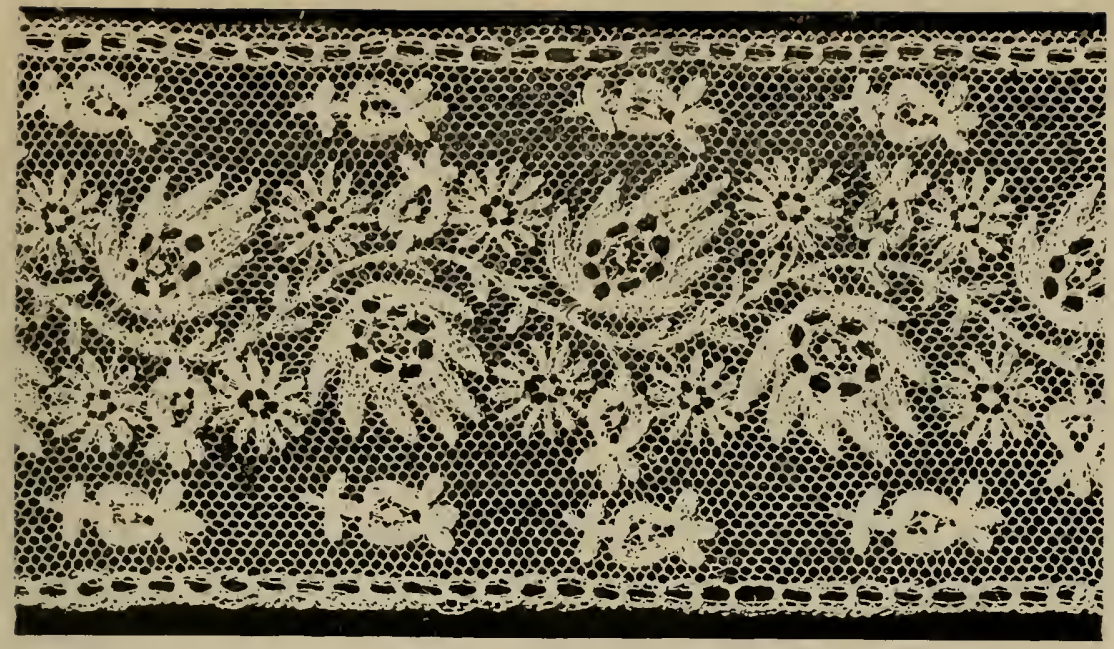

Limerick Lace.

CHAPTER VII.

\section{OF ENGLISH AND IRISH LACE.}

Linen Cut-work was made in England very extensively during the sixteenth century. It was a favourite accomplishment of the ladies of Queen Elizabeth's time, and it supplied, moreover, a profitable occupation for a large class of professional workwomen. There was an enormous demand for Lace of the finer sort for ruffs, and the thicker linen Lace was largely used to trim sheets and table linen, etc. We see it represented on the cradle monument to the infant daughter of James the First 
in Westminster Abbey, and also on the dress of her elder sister, whose recumbent figure in effigy lies hard by. An actual relic of the kind, possessing a peculiar interest, is to be found to this day in a cottage in the village of Shottery, in Warwickshire, which is still occupied by descendants of the family of Anne Hathaway, Shakespeare's wife. On an old oak bedstead in an upstairs room there is displayed the best linen sheet which, as tradition says, was kept for special family occasions, such as births, christenings, weddings, funerals, etc. It has a narrow strip, about an inch and a half wide, of Cut-work made in the linen, and joining two breadths together where there would otherwise be a seam. The pattern is of a very simple zigzag character. The bolster cover, now kept in a frame, has a rather wider band of a more ambitious design, but of the same style of work. There seems every reason to believe that this relic is authentic, and as it might very well date from Elizabethan times, it is possible that our great poet himself may have seen or even used this bed furniture in the house of his wife's parents.

Besides articles for use, domestic or otherwise, a considerable number of samplers have come down to us. They were worked at schools or kept as 


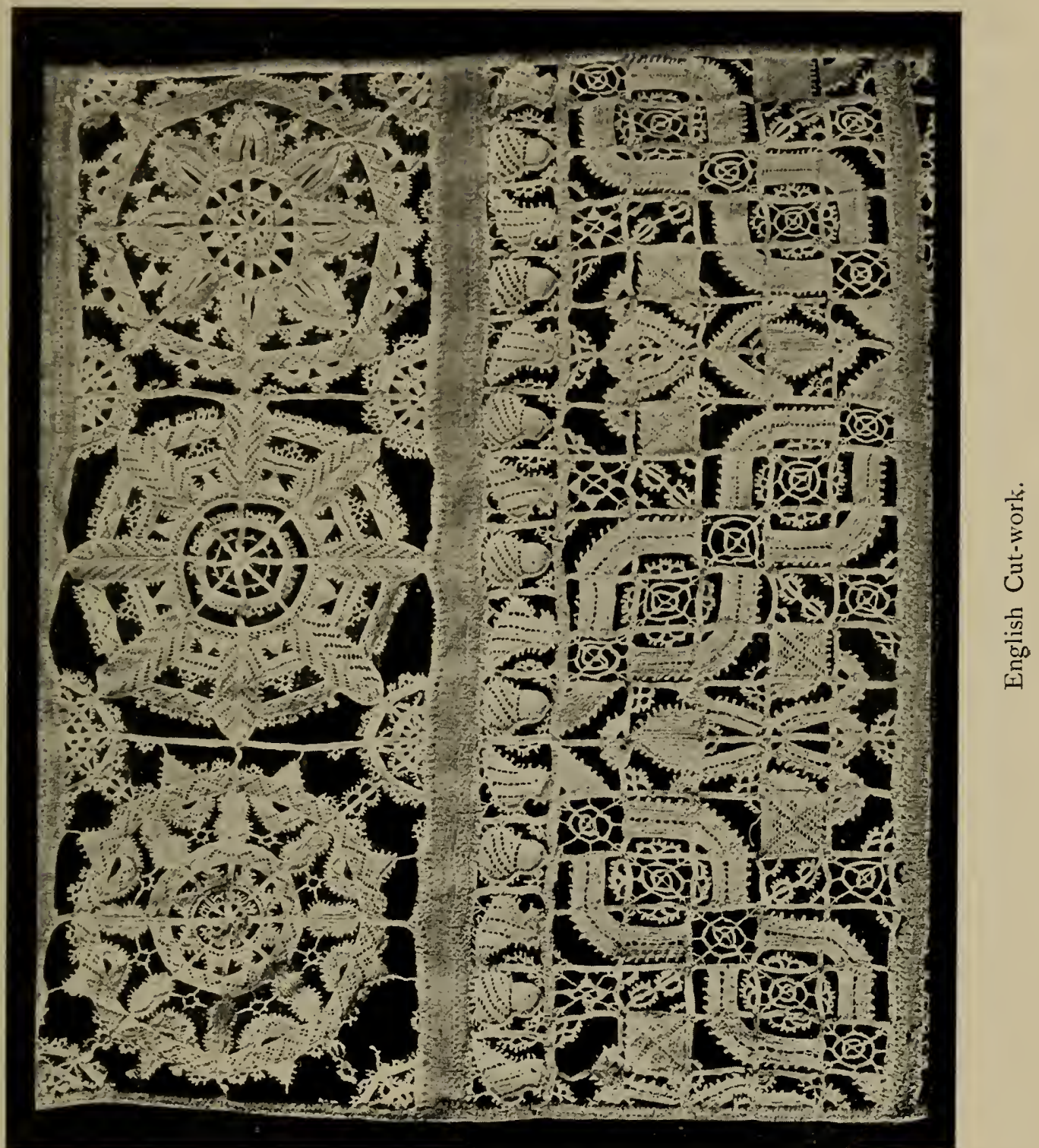



collections of patterns of embroidery by industrious housewives. Illustration XXXIX. represents part of one in the collection of the South Kensington Museum, with two patterns of Cut-work, rather clumsy and heavy in style, but, as will be seen, worked in the usual Italian manner. (See Illus. I., Fig. 5.) Bands of embroidery patterns of various kinds other than Cut-work fill up a strip of linen of about a yard and a half long. It is signed and dated "Elizabeth Mackett I696." But beyond Cutwork, no great amount of Needle lace seems ever to have been made in England. Bone lace (that is, Pillow lace) is constantly alluded to in Queen Elizabeth's wardrobe accounts, and though a good deal no doubt came from Flanders and Genoa, there is evidence to show that by the beginning of the seventeenth century the native lace-making trade was in a flourishing condition in many parts of England.

Its chief centres have always been in Devonshire (especially Honiton), Bedfordshire, and Buckinghamshire.

\section{HONITON LACE.}

It has been mentioned in connection with the name "Point d'Angleterre" that the theory is some- 
times entertained that this Lace originated in England, and was only afterwards transferred to Brussels. The probability, however, seems to be that, on the contrary, the Art came to England from Flanders, as some have supposed in consequence of an immigration of Protestants during a time of persecution. However that may be, Mrs. Treadwin mentions in her valuable book on Antique Point and Honiton, that Pillow lace of some sort was made in this district some time before the year I6I7. It was probably not at all like that now produced in Devonshire, but rather a sort of open woven braid with a simple diamond-shaped lozenge pattern of a kind still sometimes to be met with. Our present use of the word Lace in "bootlaces," etc., may be a clue to what was called Lace in early English times-namely, a plaited braid, more or less ornamental.

During the troubles of the Civil War and the Commonwealth ornament in dress was naturally in abeyance, but on the return of the Court in 1660 Lace also resumed its place in society. It was, however, speedily confronted with difficulties of a fiscal nature, when, in order to increase the revenue and also perhaps to protect native trade, prohibitive duties were put upon its importation from abroad. 
We have seen in a previous chapter how these were evaded; it was doubtless, however, at this time, and in consequence of these duties, that Flemish laceworkers must have been induced to come over to England to teach their art in Devonshire. The absolute identity in the method of working Honiton and Brussels Lace can scarcely otherwise be accounted for.

Early Devonshire Lace appears, however, sometimes to have had one peculiarity distinguishing it both from Brussels and from the later Honiton. It is the use of an outlining "cordonnet" or trolly or gimp, from which it was locally known as Trolly lace.

The development of this Lace has followed much the same course as did those of Flanders. As with Brussels "Point d'Angleterre," the pattern part of Honiton having been made first on the pillow by itself, the "réseau" in early times was worked in round it, also on the pillow; but later, after the invention of machine-made net, the principle of "appliqué" work was also adopted in England, and this cheaper and inferior material was substituted for the hand-made ground.

The difference between Honiton and Brussels Pillow lace is one of quality rather than of kind. 
English designs have been as a rule less artistic than those in use in Brussels.

Even in the best specimens produced during the early part of this century garlands and bouquets of natural flowers have been put together without much idea or knowledge of composition. The execution, also, was in general less finished and delicate than in good Brussels Lace. But these remarks apply rather to the past; of late years schools of Design and the emulation excited by International Exhibitions have much improved the character of English Lace on both points. The difference between the two specimens shown in Illustration XL. will be at once noticed. No. I represents Lace made in the early half of this century. The flower sprigs are rather thick and heavy in shape and are "appliquéd" on to machine-made net. No. 2 shows a recent production. The pattern is bold and continuous as well as graceful, and the ground is a very good needleworked "réseau"--it is a mixed Lace, in fact. Much of the best Honiton now made is in this style. A "Duchesse" lace, very similar to that made in Brussels (see Illustration XXXII.), is also now worked in Devonshire. 


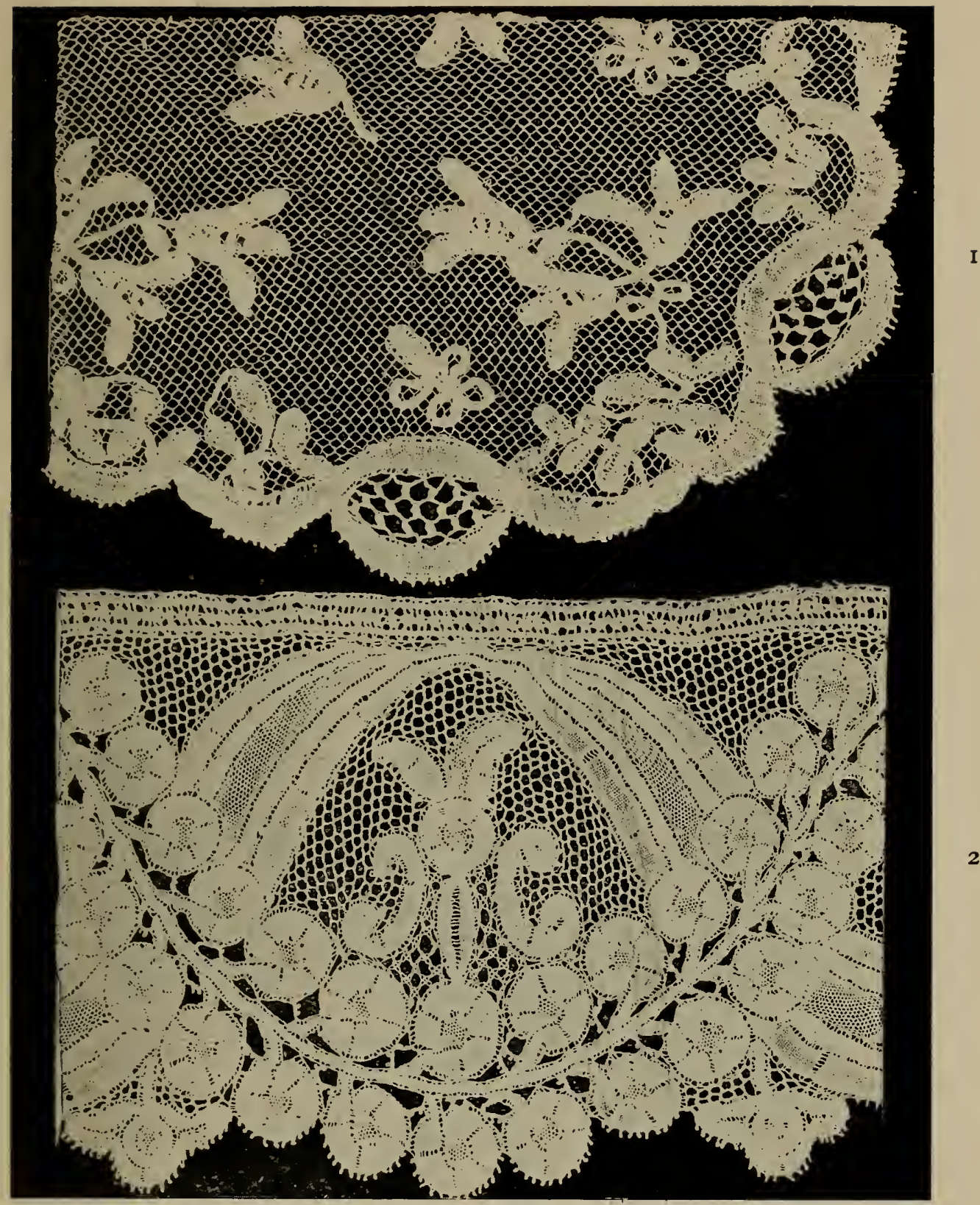

I. Honiton Appliqué. Z
2. Honiton Appliqué with needle "réseau "gruund. I69 

BUCKINGHAMSHIRE AND BEDFORDSHIRE LACE.

There is a tradition that while Catherine of Aragon, the forsaken Queen of Henry the Eighth, was living at Ampthill Park, in Bedfordshire, about 1532 , waiting with what patience she might for the decision of the Pope respecting her divorce, she beguiled her sadness by exercising her own skill in needlework and required the ladies of her household to do the same. Not only so, but she interested herself in teaching lace-making to the village women of the district, and this was the origin of the Bedfordshire lace industry. To confirm the truth of the story, it is said that till well within the present century the name-day of the kind but most unhappy lady, St. Catherine's Day, the 25th November, was annually kept as a treat-day for young lace-makers, and children expected a feast of cakes and sweets, and called the day "Kattern's Day." St. Catherine is also the patron saint of girls and unmarried women. But the Lace then taught by the Spanish princess to the Bedfordshire women was certainly not anything like the present Pillow lace; more probably it was Cutwork or Reticella made out of linen, an Art which we know to have been practised in Italy and Spain 
at the time, and which there is the early evidence of old English samplers to prove was also, though with less taste, made in England.

Some thirty years after Queen Catherine's death another impetus was given to the lace industry by the arrival in the neighbourhood of certain Flemish lace-workers, who had fled from the persecutions of the Duke of Alva, and settled in the south midland counties. These introduced a kind of Pillow lace known by the name of "Bone lace."

The earliest mention of Lace under this name is in I 554, when it is said to have trimmed the dress worn by Sir Thomas Wyatt at his execution; in the accounts of Queen Elizabeth's wardrobe the name is of constant recurrence.

After the revocation of the Edict of Nantes, in I 685, another immigration of foreign lace-makers took place, this time from the French provinces bordering on Flanders, and it is doubtless to these last that the distinctly Flemish character of the old Bedfordshire and Buckinghamshire Lace is to be attributed.

Again, in I794 it is recorded in the Annual Register that "a number of engenuous french emigrants have found employment in the manufacture of Lace" in these counties. Thus it would seem as though one foreign settlement attracted another. 


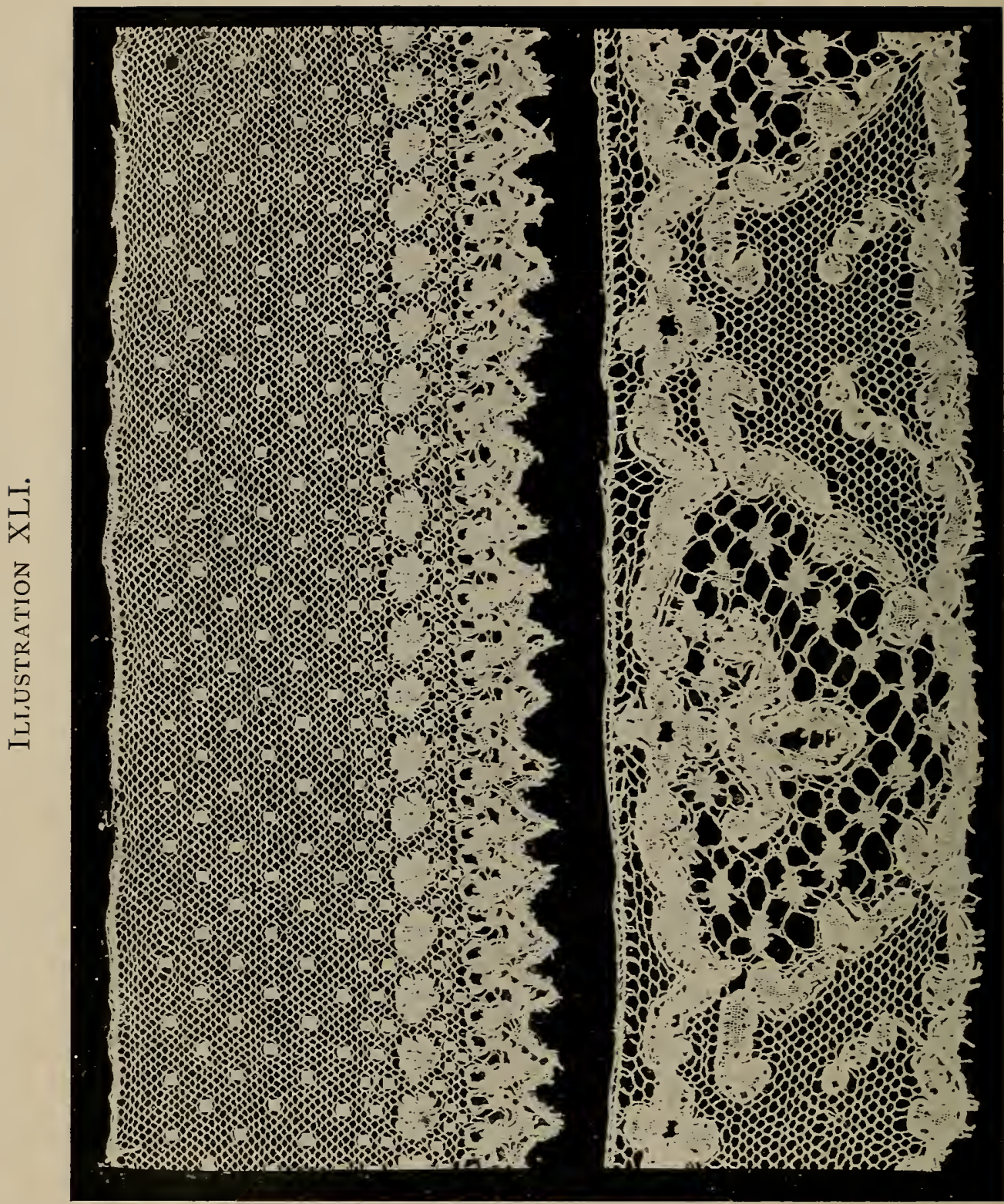

हैं

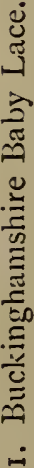


The Lace of the two counties may be classed together as being practically the same. They belong to that class of Lace which is worked in one piece on the pillow (see p. I 26), and in their general character and style of design they strongly resemble the Lace manufactured at Lille. The "réseau" ground is exactly the same as that of Lille Lace, that is, it is composed of two threads twisted and simply crossed, not plaited, at their junction. The mesh varies a little in shape, from a four-sided diamond shape to a hexagon, according as the threads at crossing are drawn tighter or left loose and long. Like Lille, the pattern of Buckinghamshire Lace is outlined with a coarse silky thread, called locally the "Trolly," from the Flemish word "Trolle."

The style of designs, also, of the English Lace has been clearly influenced by Lille models. There are often the same oval-shaped openings filled with various fancy "à jours." In No. 2, Illustration XLI., a specimen is shown which goes by the name of "Spider lace," on account of the open-work filling. No. I represents what is called "Baby lace," a variety with a finer "réseau" and smaller pattern, made on purpose for trimming baby-linen; and here again, by the small square dots on the ground, one is reminded of a frequent peculiarity in Lille Lace. 
From the time of the first Flemish settlement till almost the middle of the present century, the lace industry gave constant occupation to many hundreds of women and children in the district. Its chief centres were at Great Marlow, Olney, Stony Stratford, Newport Pagnel, and High Wycombe; but these towns were probably only where the Lace was collected from the workers, to be sold by middle-men, the work itself being carried on in most of the country villages. It was still then called Bone lace; the origin of the term is not easy to ascertain. Several explanations have been given-that the little bones of sheeps' trotters were at first used as bobbins; that till the brass pins used in lace-making for fixing the work in its place became cheap enough to be general, fishbones were substituted; also that the patterns were pricked out on thin plates of bone instead of on the parchment in later use. The fact that the Lace has also been called "Parchment lace" gives a colour to this last theory.

Old bobbins are often found made of bone instead of wood. They are sometimes very curiously decorated, indeed they seem to have been often used as love-tokens between the young people of the day. They are to be seen stained with red or other colours, 
and ingeniously turned in ribs or stripes; rings of metal are fastened to them at intervals, or brass wire is wound round them, and "gingles" or bunches of coloured beads are hung from the end strung on a loop of wire, these last being also of use in increasing the tension of the thread by adding to the weight of the bobbin; and, lastly, mottoes of various kinds are, so to speak, tattooed on them, the letters being outlined by pricked holes filled with colour. Sometimes it is the name of the giver, as "DEAR JOSEPH," which is so inscribed ; sometimes the girl's name, as "SARAH" ; and sometimes a three-lined motto, as-

"LOVE ME OR

LEAVE ME A

LONE FOR EVER."

Not only the bobbins, but the pillow also was the subject of much pride and pleasure, and even the pins were objects of ornamentation. Children gathered the little prickly seeds of the hedgerow Bed-straw (Galium) and threaded them on the pins, which, when dry, formed little brown heads as hard, and much the same colour as if made of walnut wood.

An illustration of some ornamented bobbins and also of a Lace token will be found at the end of this chapter. The latter were used by employers of 
labour as payment to their work-people at the end of the last century, when the country seems to have suffered from a scarcity of mint-coined money. They were issued as country bank-notes are now, and were redeemable at a fixed rate when presented to the central office.

IlLUSTRATION XLII.

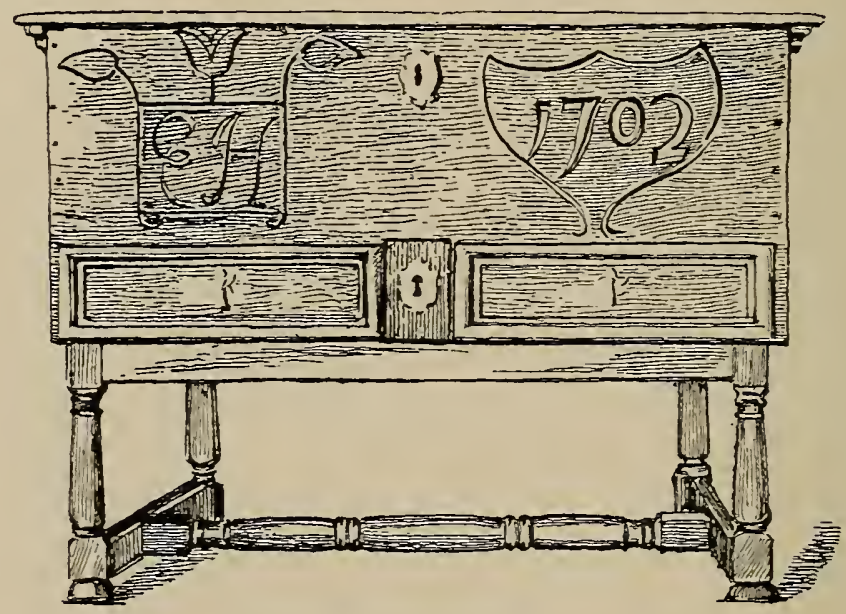

An Old Lace Chest.

The old oak chest shown above is another relic of the prosperous days of lace-making in Buckinghamshire. The upper part was intended to hold the lace pillow, while the drawers below were to take the bobbins and patterns.

It was shortly after the beginning of this century, however, that Machine lace was invented and became generally known, and thenceforward the hand-made 
Lace trade had but a precarious existence. In order to keep the favour of the purchasing public, continual changes have been made in the style of the Lace produced. Silk Lace called "Blonde"-because being made with raw silk it was "fair," not white in colourwas one of the earliest new introductions; to that succeeded Maltese and the so-called "Cluny," named after no place of its manufacture, but from the Museum of Antiquities in the Hôtel Cluny in Paris, and because the Lace was supposed to have a mediæval appearance. It is a plaited Lace, somewhat resembling the Genoese and Maltese Laces, and is made both in black silk and in white cotton. And here, alas! is the secret of the inferiority, and much of the want of success of this modern English Lace; it is almost always made of cotton, and not linen thread, the probable reason being that the material is more within the means of the cottage workers. After Cluny came coloured worsted Lace and Torchon lace, and this is now the kind mostly produced. Besides, however, the competition of steam machinery, and the consequent lowering of prices, another enemy has lately come into the field against the Buckinghamshire lace-workers, in the shape of the Board of Education. Children in former times began to learn to use their bobbins at five years old, and 
at twelve were able to support themselves entirely by their work, and it is said, with some show of reason, that unless the Art is so acquired by the workers when very young, there is but small likelihood that sufficient skill will ever be attained to make it remunerative at the low prices for which alone Lace can be sold. But the inspector insists that the children shall be sent to school, and such short time as is allowed for school instruction in work is not spent in teaching lace-making. So it comes to pass that the young girls of this generation have not learnt the work properly, and do not care to practise it; and the Lace that is made now, and for which a market is anxiously sought, is made by the old women of a former generation between sixty and seventy years old and more. And when in a few years time they must have passed away, it is to be feared that the Art of lace-making, in this district at any rate, will have disappeared also with them.

Great efforts have been and are still being made, however, to save this national Art from extinction. Exhibitions are organised, and prizes offered for the best work by such gentry of the district as are kindly disposed towards their poorer neighbours, and whatever may be the results of these 
efforts, much sympathy must be felt for their object. For, apart from the fact that one must regret to see the disappearance of any of our old English handicrafts, this one, as we have seen, has in former times been a source of great interest and pride, as well as of income, to the poor cottage women, who otherwise have so few interests and pleasures outside the weary round of their household and family duties.

No one who has known anything of the monotonous life of the English peasantry could do otherwise than regret that such an additional object of interest should be lost to them.

\section{IRISH LACES.}

Attempts have been made at various times, both during this century and the last, to assist the peasantry of Ireland by instruction in lace-making, and considerable success has often been the result. As early as 1743 the Royal Dublin Society granted prizes to be awarded by Lady Arabella Denny to those who excelled in the work; but at her death, thirty years afterwards, the undertaking came to an end. The experiment was again repeated with more permanent results in 1820 , and again in 1847 , at the time of the famine. It was then that crochet-work 
was introduced; very good patterns of old Lace were procured, and the Irish girls soon showed great skill in copying them. The work was vitiated by the use of cotton instead of linen thread, a mistake so generally made in recent Lace revivals. Cotton may look fairly well when first worked, but it does not keep its firmness and colour as does pure flax, and when washed becomes loose and woolly in appearance.

Following crochet came a better style of work, encouraged and stimulated by the "Ladies' Industrial Society," namely, Needle-point copies of old Venetian Lace. These were sometimes executed with a fair amount of skill, though, for economical reasons doubtless, the copies fell far short of the originals in the fineness and closeness of the stitches; where ten stitches were put into the old work, five or even less were made to answer the purpose in the new.

However, the Exhibition of Irish Lace at the Mansion House in ${ }^{2} 88_{3}$ did much to make it known to the purchasing public. It also encouraged those who supervised and taught the work in Ireland to raise their standard of excellence in the matter of workmanship and design, and to extend the sphere of their labours. 
But it is not intended here to give any detailed account of Lace made in convents and schools, avowedly reproductions of old Italian originals, excellent though they often are. There are, however, two sorts of work, now carried on in Ireland, to which attention may be drawn as possessing some individuality, namely, the net embroideries of Limerick and the appliqué and cut cambric work of Carrickmacross. They should both be more correctly described as embroidery than as Lace in the usual sense of the word; but as they have the appearance of Lace, and are often very excellent both in effect and design, they would seem deserving of some notice. That known by the name of Limerick Lace was first made in Nottingham at the time of the invention of machine-net. The manufacture was transferred to Ireland in the year 1829 by Mr. Charles Walker, who, while studying for Holy Orders, married the daughter of a lace manufacturer, and either moved by philanthropy or as a speculation, took over to Ireland twenty-four girls to teach the work, and settled them at Limerick. It is in reality of French origin, being the same as the "Broderies de Luneville" which have been produced in France since 1800 .

It is worked in two ways, either by embroidering 
the pattern with a darning stitch on the net, as shown in the little heading to this chapter, or with tambour stitch; spaces left in the pattern are filled in with ornamental "à jours" also worked on the net.

Carrickmacross is either appliquéd on net or cut out with a ground of "brides;" either way it is worked on muslin. The pattern is traced with close sewing, and the muslin is then cut away outside the outline. (See Illustration XLIII.)

\section{MACHINE-MADE LACE.}

In enumerating the various kinds of Lace made in Great Britain, it would not be fair to omit all mention of the productions of the Nottingham looms. It is true that as imitation Lace they are considered to rank very low in the scale of Art; but in point of execution and as marvellous triumphs of mechanical ingenuity, they surely invite admiration. If we wonder at the work of the skilful hands of the Venice and Brussels lace-makers, it may, from certain points of view, be a matter of even greater wonder that human intelligence should have compelled steam and machinery to do so nearly the same. So nearly, yet not quite. 


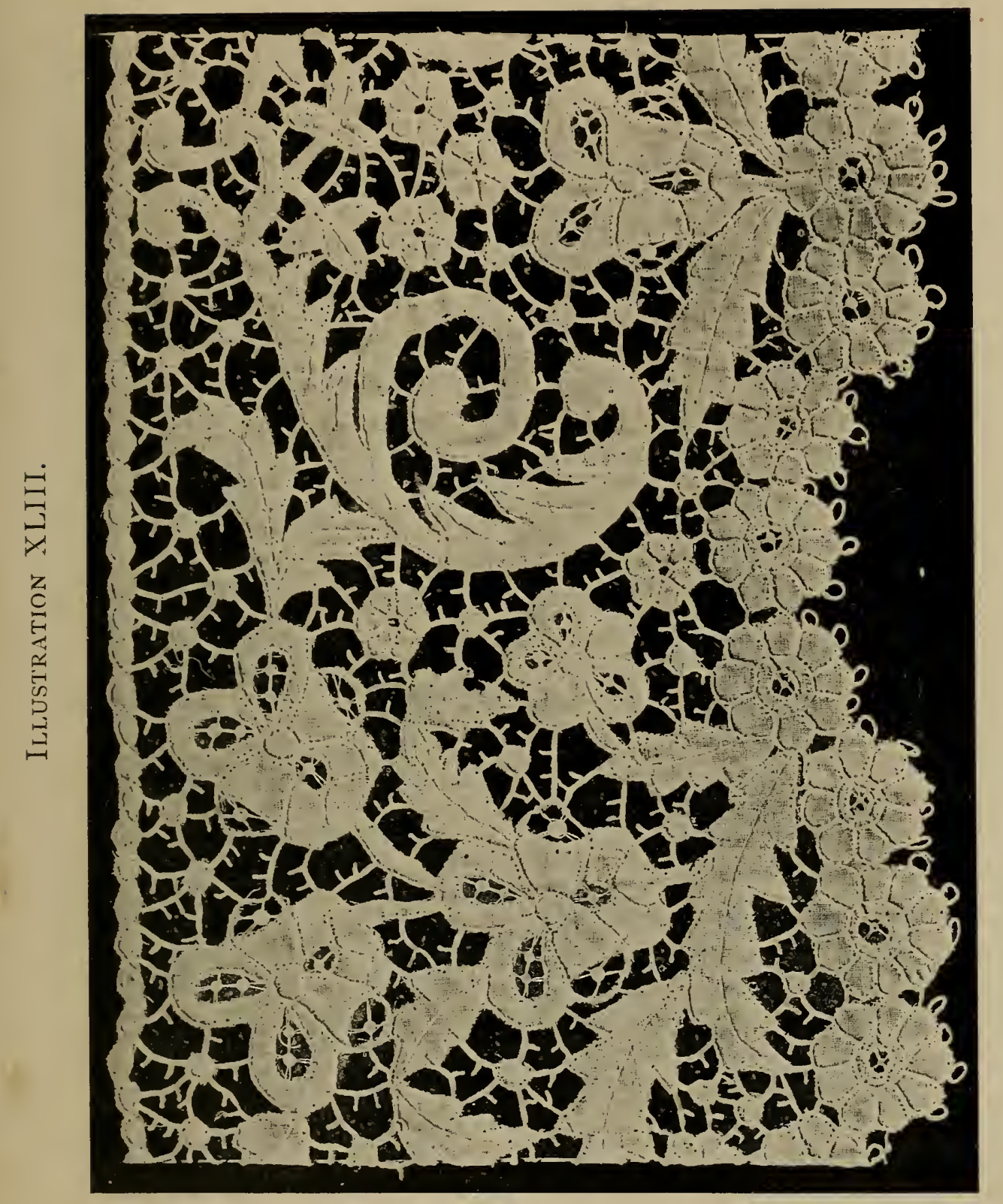



The lace-making machine was evolved in Nottingham out of the stocking-loom; and it will be readily understood that the difficulty was not so much to make the "toile" for the pattern-the stocking stitch was at first used as an equivalent for that-as to modify the machinery so as to divide the threads and produce the open net-work. The first idea of this invention is attributed to a common factory hand, Hammond Lindley, who, one day about the year 1760 , looking at the Pillow lace on his wife's cap, conceived a plan by which he could copy it on his loom. Improvements worked out by different inventors succeeded each other, till at last, in $18 \mathrm{ro}$, a fairly good net was produced. It was called "Point net," and in connection with it a considerable industry sprang up in Nottinghamshire and the surrounding district. Thousands of women were employed in embroidering on this net, both by darning and tambour work. It is the work referred to already in the section on Irish Lace, as now known by the name of Limerick Lace. In the beginning of this century this Art seems to have been practised not only in Nottinghamshire but in many other parts of England, for the writer has lately seen a net scarf so embroidered, the work of an old lady upwards of eighty, still alive, who says that she made it when a child in the village 
school at Woolhampton in Berkshire, where the work was taught as part of the school education of the day.

But to return to Nottingham. By the time of our gracious Queen's accession, not only net, but also very good imitations of Flemish Lace had been achieved, and the extremely effective machine Lace of all kinds since produced is well known.

If it should now be asked by what signs such imitations can be detected, the answer to this inquiry must be, to a certain extent, a negative one. Machine lace is Not made with looped stitches like Needlepoint lace, nor do we find in it the effect of plaited threads as in Pillow lace, and where neither of these easily recognised features can be discovered, the piece of Lace under examination may fairly be presumed to be imitation. As positive indications it may be observed that the "toile" " of Machine lace is often found to be ribbed, like the ribbed texture of a knitted stocking; also that whereas old Needle and Pillow lace is always worked with linen thread, Machine lace is very generally made of cotton.

It would be hopeless to attempt to describe the various substitutes for the hand-made lace-stitches which the machine-lace maker has invented; they are legion, for what he cannot achieve in one way 
he does in another. Nevertheless, needle-lace imitations were generally till lately very easy of detection. But where man intends to succeed diffculties seldom prove insuperable. Invention this time has come from Switzerland, and in connection with the well-known Swiss industry of embroidery on cambric and muslin. One José Heilmann, a native of St. Gall, pondering on the work of his wife's needle, thought to himself that if spinning, weaving, and printing were done by machinery, then why not embroidery? He made his wife teach him to embroider, and in six months' time he had invented a machine that worked with six needles at once. His first thought was to take it to England; but there, though his invention had many admirers, it did not find a purchaser. It was in 1838 , at a time when England was so far in advance of the Continental nations of Europe in machinery, that the great heads of the manufacturing firms thought they could afford to despise foreign ideas.

Heilmann returned home, and a Swiss shopkeeper, Mange, bought his machine. It was rapidly perfected, and by 1868 hundreds of machines were turning out most excellent work.

This has recently been applied to the imitation of Venetian Point lace, with the result that a nearer 
approach than ever before has been made to the reproduction both of the needle-worked "toilé" and also of the "bride" work.

Yet, when so much is conceded, there remains the indubitable fact that the productions of machinery can never possess the charm of the real hand-made work. Musicians tell us that the performance of a piano-organ, even the most perfected of its kind, is flat and uninteresting as compared with the music produced by a fairly good performer. Even so with Lace made by machinery; the most perfect must by reason of its very perfection lack the impression of life which the very faults and irregularities of human handiwork can alone produce. We are so made that the imperfect even, pleases us more than the perfect, if it tells us that human beings have expended time and zeal in their efforts after perfection.

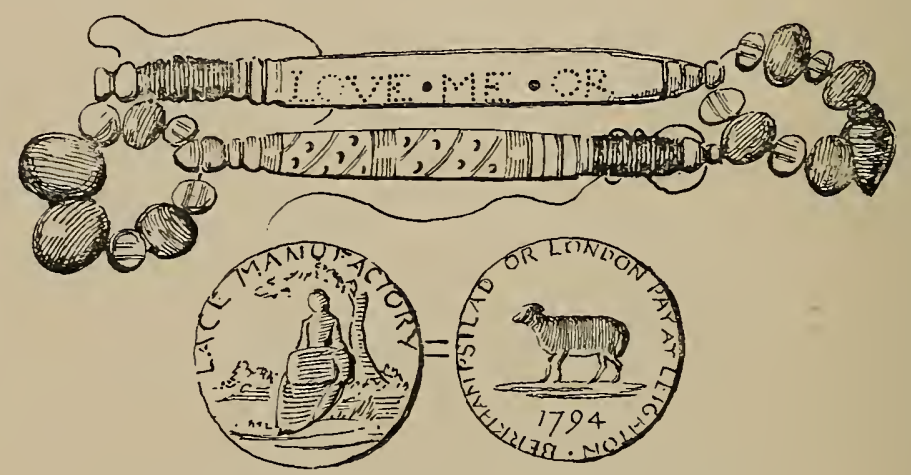

Old English Bobbins and a Lace Token. 


\section{A SUMMARY}

As a summary of what has been written in the foregoing chapters, the following few simple statements may be found useful :-

I. Lace worked out of linen, though originating in Italy, was also worked with no great variation of style in Spain, France, and England, and in the Greek islands; the designs are usually geometrical. (See p. 24.)

2. The words "Point lace," properly used, signify Needle lace only, and are misused when applied to any Pillow lace whatever. (See p. xv.)

3. The earliest Point lace was made with "brides." It was chiefly made in Venice. Some was produced at Alençon for a short time during the latter half of the seventeenth century in imitation of Venetian Point, and some may have been made in Spain.

4. Point lace with "brides" was not made in Flanders. (See p. I 39.) 
5. Point lace with a "réseau" ground was invented and chiefly made at Alençon. The style was adopted, both in Brussels and Venice, towards the close of the eighteenth century. Brussels Needle lace is most frequently grounded with a Pillow "réseau." (See pp. 98, 143.)

6. The most marked distinction between Point and Pillow lace is that in the former the solid parts are seen to be made of looped button-hole stitches, while that of the latter resembles woven cambric or cloth in texture. (See p. 6.)

7. Pillow lace divides itself into two classes, according to the method of its construction.

(I) When the pattern is worked by itself on the pillow and the "réseau" ground is worked in afterwards to fit round it. (See p. 82.) To this class belong "Punto di Milano," Brussels Pillow lace, and Honiton Lace.

(2) When the Lace is made all in one piece on the pillow, the same threads forming both "toile" and "réseau" alike. (See p. I 27.) To this class belong the Italian peasant Laces, all French Pillow lace, all Flemish Pillow lace, except Brussels, and all English Lace except Honiton. 
8. Pillow lace made with "bricles" is earlier in point of date than that made with a "réseau" ground. (See p. 122.$)$

9. Various Pillow laces are to be distinguished from each other chiefly by the construction of their "réseau." (See p. 7.)

Io. Machine-made Lace was invented towards the end of the last century, and was not perfected till the beginning of this century. (See p. I 87.) Any Lace, therefore, known to be older than 1800 must be either Point or Pillow lace.

THE END 



\section{NDEX}

Adriatic, 49.

Aix-la-Chapelle, I I 3 .

A jours, xv, 7I, 8I, 98, II4, I5I, 175.

Alb, Cardinal's, 38 .

Alençon, 9, I 3, 50, 55, 61, 97, го2, I39, I40, I9I, 192 .

- Point de, 9I.

Altar frontal, 38 .

Alva, Duke of, 172.

Ampthill Park, I7I.

Angleterre, 92.

Anmual Register, 172.

Antwerp, I47, I 58.

Annunciation, 158.

Appliqué, xv, 136, I67.

Aprons, 33, 37.

Arachne, Io.

Argentan, 102.

Argentella, 98.

Athene, II.

\section{B}

Baby lace, 175.

Bayeux, II 4.

Bedfordshire, I65, I7 I, I72.

Bed-straw, I77,

Belgium, I2, 67, 68, 102, I22.

Berkshire, I 88.
Binche, 147, I 52.

Birds, 19.

Blonde, 63, I 4 4, II7, I 79 .

Board of Education, 179.

Bobbins, xv, I, 6, 60, $176,177,178$, I79.

Bolbec, I 8.

Bolckow, Mrs., 42.

Bolster, 60, I62.

Bone, xv, 176.

- lace, xv, 33, 165, I72, I 76.

Border lace, 7576 .

Bosse, Abraham, 96.

Braid, 27, 38.

Breeches, 37 .

"Brides," xv, 2, 5, 42, 45, 46, 63, 7 I, $72,76,97,122,136,139,184$, I 9 I, 193.

"Brides picotées," 32, 49, 7I, I 32.

"Bride"-work, 42, I05, I 90.

Broderies de Luneville, I 83.

Brussels, I 2, I 3, I48, I66, I67, I68, I 84, I 92.

- Lace, 59, 62, I26-147, I48, I68.

- Needle lace, 192.

— - Point, I39, I40.

- Pillow lace, І26, І27, І28, 192.

- Point, I40, I43, I47.

— - plat appliqué, I 57 
Buckinghamshire, 157, I65, I7 I, I72, I75, I78, I79.

Burano, I2, 4I, 55, 56, 59, 6I.

- Point, 6I.

Button-hole stitch, 2, 5, 23, 36, 42, 6I, 67, IOI, 102, I40, 192.

Byzantine, I 9 .

- mosaics, 64 .

\section{C}

Caen, I I 4 .

Calvados, I I 7 .

Canons, 37.

Cantì, 8 I.

Caps, 37.

Cardinal's Alb, 38 .

- Point, 38 .

Carnation, I06, I 5 I, I 58.

Carnival lace, 38 .

Carrickmacross, I83, I84.

Catalonia, 63.

Catherine of Aragon, I7 I.

-, Queen, I72.

Ceccia la Scarpariola, 56, 59 .

Chantilly, I I 4, I I 7 .

Charles the First, 36 .

- the Second, 38.

Chichester, Lady Hamilton, 88.

Church furniture, 27.

- linen, 28.

Cluny, I79.

Col rabattu, 36 .

Colbert, 9I, 97.

Cole, Mr. Alan, I25.

Collar lace, 75 .

Collars, 32.

Cologne, 34 .

Commonwealth, The, I66.
Coqués, Gonzales, I 25.

Coral, 49.

Coraline Point, 49.

Cord, xv.

Cordonnet, $\mathrm{xv}, 16,42,45,6 \mathrm{I}$, 63, IOI, IO2, I I 4, I 40, I 48, 167.

Corfù, 24.

Cotton, I4, I79, I82.

Coverlets, 38.

Crochet work, $18 \mathrm{I}$.

Cuffs, 33, 37 .

Cut-work, 5, IO, I3, 1 5, 23, 24, $27,28,3 \mathrm{I}, 34,35,16 \mathrm{I}, \mathrm{162}$, I65, I7 I.

\section{D}

Dalmatian coast, 96.

Darned netting, I, 6, I5, 19, 125, I 26.

Darning stitch, I84.

Denny, Lady Arabella, I8 r.

Dentelle au fuseau, xv.

- d'Angleterre, 95.

- noire, 95 .

Devonshire, I66, I67, I68.

Dieppe, I I7, I I8.

Distaff, I 4 .

Dogs, I9.

Drawn-work; 5, I 5, 16, 23.

Dublin, Royal Society, I8I.

Duchesse lace, 168.

- Point, 136.

Écru, I I 4.

$\mathrm{E}$

Elizabeth, Queen, I I, I2, 33, I6 I, I65, I72. 
Elizabeth Mackett, 165.

Embroidered netting, 35.

Embroideries, 33, 92.

Embroidery, 14, 23, 165, 189.

Empire, The, 12, 98, 117, 152.

England, 132, 151, 165, 166, I67, I 72, I87, I89, I9I.

English Lace, I6I-I8I, I92.

Eu, iा8.

Exhibition of Irish Lace, 182.

- International, I68.

\section{$\mathrm{F}$}

Fambri, M. Paulo, 56.

Fécamps, I I 8.

Fishbones, 176.

Flanders, 13, 68, 95, I I3, I 1 7, 12 I, 122, I 39, I58, I65, I66, I67, I72, I9I.

Flandres, 92.

Flaxen, I I 4.

Flemish Lace, 75, I2 I-I60, I 88.

- pillow lace, I 92.

- Provinces, 68, 7 I, 97.

Florence, 87.

Fond chant, I I4, I48, I 58 .

- clair, I 13.

- de brides, 126.

- de neige, I48, I 52.

- simple, I I3, I I 4 .

France, 37, 49, 63, 68, I02, I I 7, I 32, I 39, I 83 , I 9 I.

一, Isle de, Io6.

French lace, 9I-I 9.

French pillow lace, 192.

Frontal, altar, 38.
G

Genoa, I 3, 64, 75, 76, 88, 98, I65.

Genocse collar lace, 87 .

- Lace, 75, I79.

- tape guipure, 76,8 r.

Geometrical, I 4, 15, 23, 31.

George the First, I 35 .

George the Second, 135.

Gerrardo, Marc, 33.

Gheltof, Urbani, 60.

Gimp, xv, 38, 92.

Gold, 27, 33, 35 .

Great Marlow, 176.

Greek Islands, 19, 24, I9I.

- Lace, I 3, I 5, 24.

Gros point, 49.

- - de Venise, 38, 4I, 42, 45.

Gueuse, 92, 95.

Guiper, $x v$.

Guipure, $x v, 38,63,72,92$.

— d'Art, 20.

- façon d'Angleterre, I 39.

$\mathrm{H}$

Hand-looms, I4.

- -made lace, I, I78.

-- spun thread, I28.

Hathaway, Anne, I62.

Havre, i 18.

Head-dresses, 32.

Heilmann, José, I 89.

Hemstitch, 24, 32.

Henry the Fourth, I 3.

- the Eighth, II, I7I.

High Wycombe, 176.

Holbein, I I. 
Holland, 125.

Honeycomb à jours, 98 .

Honfleur, I I 8.

Honiton, 165, 167, I68, 192.

- Lace, 165, 192.

- point, $\mathrm{xv}$.

Horse-hair, ıọ.

Horses, 19.

Huguenots, i 3 .

Hunsdon, Lord, 33.

\section{I}

Industrial Society, Ladies', I82.

Ionian Islands, I3, 24, 27.

Ireland, I8I, I83.

Irish Lace, I6I, 181-I84, 187.

- - Exhibition of, 182.

Isle de France, Io6.

Italian Lace, I3, I4-88, I2 I, I 22.

- Needle lace, I4-63.

- Peasant lace, 82, 87, 192.

- Pillow lace, 64-88, I 22.

Italy, I 5, 37, 45, 67, 68, 75, I7 I, I9I.

Italy, North, I 3.

$\mathrm{J}$

James the First, 36, I6r.

\section{K}

Kattern's day, I7 I.

King (of Italy), 56.

Knotted lace, 64 .

- work, 35.

Knots, xr.
Lace chest, 178.

- makers, 60, II7, I43, I5 I, I52, I 72.

— making, I 2, I3, 6I, I05, I 35, I 39.

-- pillow, I78.

-- tokens, 177, 190.

— workers, I35, I67, I72.

Lacis, I, I 5, I9, I25.

Ladies' Industrial Society, I 82.

La Fontaine, ror.

Lamb, 20.

Larmes, Semé de, IoI.

Lawne cut-work, 33.

Lead, $\mathrm{xr}$.

Leather boots, 37 .

Lely, Sir Peter, I25.

Le Puy, I I4.

Lille, I I 3, I I 4, I75.

Limerick, 183 .

- Lace, I83, I87.

Lindley, Hammond, I 87.

Linen, I2, I4, I 5, I6, I9, 23, 24, 27, $31,32,35,38,45.71,161,162,17 \mathrm{I}$, I 79, 19 I.

Longueville, Duchesse de, I I 7 .

Lonray, 97.

Louis the Fourteenth, 37, 9I.

- the Fifteenth, 132.

- the Sixteenth, 98.

Louvain, II.

Machine lace, I, I78, I84-I90, I93.

- -made net, I35, I36, I43, I67, I68.

Mackett, Elizabeth, 165.

Macramé, 64, 67. 
Malines, 148 .

- à brides, 15 I.

Maltese Lace, 88, I79.

Mange, i 89 .

Mansion House, I 82.

Mantillas, I I 7 .

Mantua, Princess of, 32.

Marcello, Countess Adriana, 59.

Marie Antoinette, I 5 I.

Marq, Catherine de, 97.

Mary Tudor, Queen, I I.

Matsys, Quintin, I I, 67.

Mechlin, 9, II3, I47, I48, I 5 I, I75.

Mediæval, I4, 15.

Medicis ruff, 32 .

Merletto à maglia, $\mathbf{1 9}$.

Merletti à Piombini, xv.

Mezzo punto, 7I, 72.

Milan, 8I.

Milanese pillow lace, $8 \mathbf{I}$.

Mixed lace, 7 I, I 32.

Moorish taste, I 9.

Museum, Hôtel Cluny, I79.

- of the Arsenal, Venice, 67.

- British, 35.

- South Kensington, 20, 34, 38, 42, 45, I2 I, I25, I65.

Mythical animals, 19.

$\mathrm{N}$

Nantes, Edict of, 172.

Naples, $72,87$.

National Portrait Gallery, I I.

Needle lace, 12, 13, 19, 23, 27, 7 I, I02, I43, I65, 191.

- Point lace, I, 2, 5, 6, I 3, 20, 28, 59,72 .
Necdle Point, 31, 75, 91, 98, I 32, I $36,144,182$.

Needlework, xv.

Network, 6, I6, I 87.

Newport Pagnel, 176.

Normandy, II 7 .

Nottingham, 135, I83, I84, I87, I88,

Nottinghamshire, 187

\section{$\mathrm{O}$}

Eil de Perdrix, 148.

Olney, I 76.

Oncagnia, Signor, 35 .

Oriental, I9.

Pagan, Matthio, 35.

Palliser, Mrs., 34, 56, 88, 98, I 52.

Parchment, 46, 72.

- lace, 176.

- patterns, Io, 6o.

Paris, 34, 106, II7.

Passemens, La Révolte des, 92.

Pattern books, 34 .

Peasant lace, 82, 87.

Pelican, 20.

Picots, xv, 2, 5, 24, 42, 45, 7I, 8I, I 3 .

Pillow, 5, 60, I27, 135, 147, 175, I77, 178.

- cases, 28, 38 .

- Guipure, 68, 71, 72, 75, 82, I2I, I26.

- lace, xv, I, 5, 6, 9, I0, I 3, 33, 64, $67,68,7 \mathrm{I}, 75,8 \mathrm{I}, 82,97, \mathrm{I02}, 105$, I 22, I26, I28, I 39, I 43, I47, I65, I66, I67, I7 I, I72, I87, I88, I9I, I92, 193 . 
Pillow lace making, II 7 .

Plaited lace, 76 .

Point, xr.

- appliqué, I 43 , I 4 .

- coupé, 23.

- d'Alençon, 6r, 9r, 95, 98, JOI.

- d'Angleterre, $\mathrm{xr}$, 62, IjI, I 32 , I $43,151,165,167$.

- - à brides, 132 .

- d'Argentan, 59, 102.

- de Canaille, 7 I.

- d'Espagne, 38,62 .

- de France, 97.

— de Gaze, I 40, I 44, I 47.

- de Gènes, 92.

- - frisé, 76 .

- de Neige, 45.

- de Paris, I06, i 4.

— de Raguse, 92, 96.

— de Venise, 38, 92.

- - à réseau, $4 \mathrm{I}$, 50 .

- duchesse, г 36 .

- lace, xi, 6, 9. 36, 37, 72, I9I, 192, I 93 .

-- net, I87.

- plat, 4I, 49.

- - appliqué, $\mathrm{I} 36$.

- - de Venise, +1 .

Pompe, Le, 67.

Pope, The, 56, I71.

Pope's Point, 38 .

Pot Lace, i 58 .

Potten Kant, $1 ; 8$.

Protestants, I65.

Punto a festone, 5,36 .

- a groppo, 64 .

- a maglia, I, I9, I25.
Punto di Burano, +1 .

- di Genoa, 23, 36, 75, 76, $8 \mathrm{I}$.

— di Milano, xr, 81, 82, r92.

— di Venezia, 37.

- in Aria, $31,32,35,36$.

— tagliato, $2 \hat{\mathrm{j}}$.

- - foliami, $37,38,4 \mathrm{r}$.

- tirato, I6.

\section{Q}

Queen, The, I8s. - (of Italy), j6, j9, 61.

\section{$\mathrm{R}$}

Ragusa, 92, 96.

Raised Tenetian Point, $\jmath \delta, 4 \mathrm{I}$, 42.

Renaissance, I4, I5, 20, 45, 71, 105. 106, I21, I22, I40.

Réseau, $\mathrm{xr}, 2,5,6,16,55,60,6 \mathrm{r}$, $72,82,97,98$, 101, 102, 105, 106, I I 3, II $4,122,125,126$, I 28, I 3 , I $35,136,139,140,143,144,148$, I 5 I, I52, I57, I67, I68, I75, 192, 193.

一, vrai, I3I, I35, I43, I44.

Reticella, 5, 15, 23, 24, 27, 28, 32, 36, I7I.

Rerolution, The French, I 2, 5j, I1 3 , I 7 , I I 8,135, I 52 .

Richard the Third, 27.

Rococo, I 4, I ; I6, 55.

Rome, 87.

Rope stitch, $2 \hat{3}$.

Rose, ז Һ̆l.

Rose point, $38,+1,45,46$.

Roses, 98. 
Rosettes, 37, 45.

Rousseau, J. J., I 2.

Rubens, 75 .

Ruff, Medicis, 32 .

Ruffs, 12, 33, 34, 16 I.

\section{S}

Samplers, 162, 172.

Satin stitch, 23 .

School Inspector, I 80.

Seed pearls, 33 .

Seguin, M., 68, I 32.

Sevigné, Madame de, 92.

Shakespeare's wife, 162.

Sheeps' trotters, 176 .

Sheets, 28, 87, 162.

Shoes, 37 .

Shottery, 162.

Silk, 16, I9, 20, 27, 35, 45.

-, black, 88, 179 .

-- lace, 179.

-, white, 88.

Silver, $27,33,35$.

Sleeves, 37 .

South Kensington, 68.

Spain, 19, 37, 41, 49, 17 I, I91.

Spaniards, 63 .

Spanish lace, 62.

- mantillas, 63, I 17 .

- Point, I3, I5, 4I, 62.

Spider lace, I 75 .

Stalks, xv.

St. Catherine's day, I 7 I.

St. Gall, I89.

St. Germains, 95 .

St. John in Valetta, 88.
Stocking loom, 187.

Stony Stratford, 176.

St. Peter Louvain, I I.

Sully, I I3.

Switzerland, I89.

Table-cloths, 28,87 .

- covers, 38 .

- linen, 33, I6I.

Tambour stitch, I 84 .

Tape, xv, 38, 71, 72, 75 .

- guipure, 76, 8I .

Ties, xv.

Toilé, xv, 2, 5, 102, 127, I28, I31, I 40, I 44, I 52, I 89, 190, I92.

Torchon, 92, 179 .

Towels, 28, 87 .

Treadwin, Mrs., 166.

Trolle, I75.

- Kant, 157.

Trolly, I 57, I67, 175.

- lace, I67.

Trousse, Mdlle. de la, 92.

Truchet, Rev. Père, 34 .

\section{$\mathrm{V}$}

Valenciennes, 10, 82, I02, 105, 117, I 18, I31, I 57 .

—, Fausse, Io6.

-, les eternelles, 106.

-, vraie, 105, 106, 157.

Vandyke, 36, 75 .

Vandykes, 32 .

Venetian dominions, 96 .

- lace, 4I, 42, 50, 92, I 82. 


\section{INDEX}

Venetian point, $15,37,38,4 \mathrm{I}, 49$, 62, 72, 97, 189, I9I.

- Point, flat, 4I, 46.

- - grounded, 4I, 50, 55 .

- - raised, 4I, 42, 59, 62.

- Republic, 24, 55.

Venice, I2, I 3, I 9, 35, 36, 4I , 49, 56, $61,67,75,92,96,121,139,191$, I 92.

Verbiest, Fräulein, I 25.

Vertue, 33 .

Vetturino, 87.

Vinciolo, 126.

Virgin, The, I 58.

Waist scarves, 37 .

Walker, Mr. Charles, I83.

Warwickshire, 162.

Weaving, 6, 20.

Westminster Abbey, 38, 162.

Wheat, Ears of, 76, 88.

White lead, 144 .

Wood, xv.

Woolhampton, I 88.

Wyatt, Sir Thomas, 172.

Y

Ypres, 10, 102, 147, 157. 
PLYMOUTH

WILLIAM BRENDON AND SON

PRINTERS 





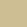


SMITHSONIAN INSTITUTION LIBRARIES 